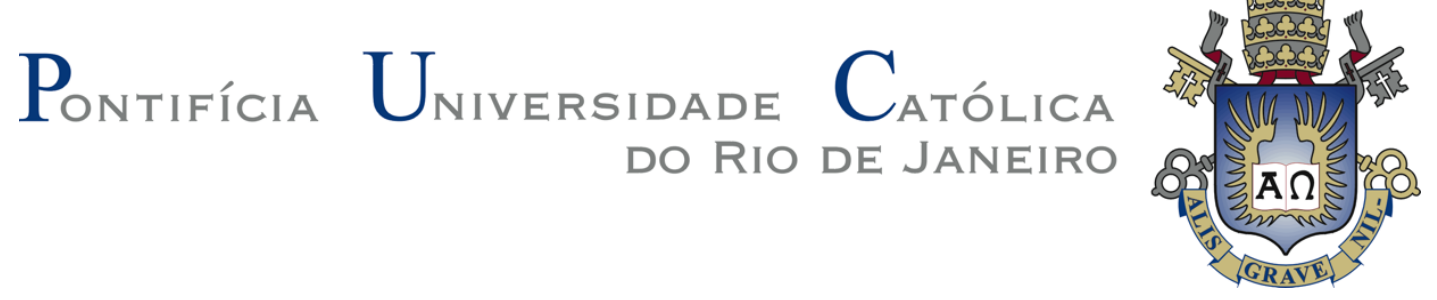

Suzana Teixeira de Macedo

Tudo significa, as coisas

Dissertação de Mestrado

Dissertação apresentada como requisito parcial para obtenção do grau de Mestre pelo Programa de Pós-Graduação em Literatura, Cultura e Contemporaneidade do Departamento de Letras do Centro de Teologia e Ciências Humanas da PUC-Rio.

Orientador: Prof. Frederico de Oliveira Coelho 


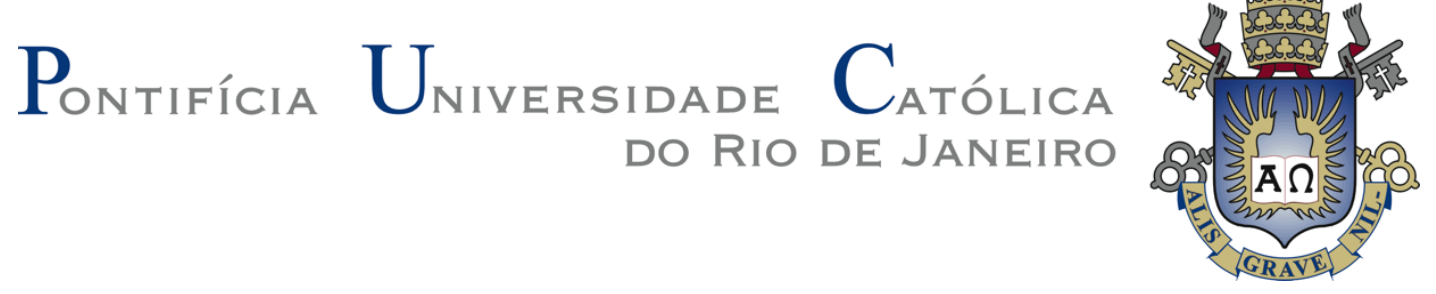

Suzana Teixeira de Macedo

\title{
Tudo significa, as coisas
}

Dissertação apresentada como requisito parcial para obtenção do grau de Mestre pelo Programa de Pós-Graduação em Literatura, Cultura e Contemporaneidade do Departamento de Letras do Centro de Teologia e Ciências Humanas da PUCRio. Aprovada pela Comissão Examinadora abaixo assinada.

\author{
Prof. Frederico Oliveira Coelho \\ Orientador \\ Departamento de Letras - PUC-Rio
}

Profa. Marília Rothier Cardoso

Departamento de Letras - PUC-Rio

\section{Profa. Ana Luiza Borralho Martins Costa \\ UFRJ}

Profa. Monah Winograd

Coordenadora Setorial do Centro de Teologia

e Ciências Humanas - PUC-Rio

Rio de Janeiro, 27 de abril de 2017 
Todos os direitos reservados. É proibida a reprodução total ou parcial do trabalho sem autorização da universidade, da autora e do orientador.

\section{Suzana Teixeira de Macedo}

Graduou-se em Ciências Sociais pela Universidade Federal de Juiz de Fora, 1983. Trabalha como pesquisadora, roteirista e diretora na área do audiovisual. Criou, escreveu e dirigiu a série Livros que Amei exibida no Canal Futura e Canal Curta!, 2012/2017. É professora da Escola de Cinema Darcy Ribeiro, desde 2010.

Ficha Catalográfica

Macedo, Suzana Teixeira de

Tudo significa, as coisas / Suzana Teixeira de Macedo ; orientador: Frederico de Oliveira Coelho. - 2017.

$235 \mathrm{f}$. ; $30 \mathrm{~cm}$

Dissertação (mestrado)-Pontifícia Universidade Católica do Rio de Janeiro, Departamento de Letras, 2017.

Inclui bibliografia

1. Letras - Teses. 2. O recado do morro. 3. Guimarães Rosa. 4. Fala e escrita. 5. Documentário. I. Coelho, Frederico de Oliveira. II. Pontifícia Universidade Católica do Rio de Janeiro. Departamento de Letras. III. Título. 


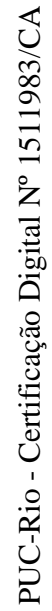

Para a Marília 


\section{Agradecimentos}

Aos moradores de Morro da Garça.

À CAPES e à PUC-Rio, pelos valorosos auxílios concedidos.

Aos funcionários do Departamento de Letras da PUC, em especial ao Rodrigo, Digerlaine e Francisca, pela eficiência, gentileza e simpatia.

Ao Tadeu Capistrano, pelos comentários e contribuições na Qualificação.

Aos professores da PUC-Rio, em especial à Marília Cardoso, Helena Martins, Ana Kieffer e Fred Coelho, pelas aulas inspiradas e instigantes.

À Rosana Kohl Bines e à Ana Chiara, presenças enriquecedoras.

Aos colegas do mestrado, em especial ao Francisco, Maria Silvia, Ramon, Maria, Marina M., Marina B., Clarice e Ana Cecília, por tornarem a vida mais divertida.

À Ana Luiza Martins Costa, pelas indicações de leituras, pelas contribuições ao trabalho e por aceitar o convite para compor a banca.

Ao Fred, pela orientação, os livros emprestados, a descomplicação.

À Sofia Karan, por me mostrar o caminho da PUC.

À Leila Name, pelo exemplar d'A Boiada, que me acompanhou durante toda a pesquisa.

À Izabel Aleixo, pelas tardes em torno d'O recado do morro', quando tudo começou.

À Renata Catharino, pela dedicação ao filme, a presença amável, a solidariedade.

À Luísa Marques, pela cumplicidade, as trocas, as ajudas todas, fundamentais.

À Marília Cardoso, de novo e nunca o suficiente, pelo acompanhamento da pesquisa, as observações certeiras, o olhar arguto, a generosidade.

À Monica, pelo interesse e entusiasmo com o meu trabalho e por me ensinar a ouvir.

Ao Nando, pela contribuição preciosa ao filme, a parceria, o entendimento.

À Catarina, pela importante participação no filme.

Ao Dudu e à Martha, pelo pontapé inicial e a casa em Morro da Garça.

Ao Leo e à Lu, pela solidariedade na hora difícil.

Aos meus pais, pelo amor que me sustentou até aqui.

Ao José, entre tantas coisas, pela alegria de vê-lo gostar do mesmo que eu gosto.

Ao Davi, entre tantas coisas, pela alegria de vê-lo gostar do que ele mesmo gosta.

Ao Serginho, a minha sorte grande. 


\section{Resumo}

Macedo, Suzana Teixeira de; Coelho, Frederico de Oliveira. Tudo significa, as coisas. Rio de Janeiro: 2017. 235 p. Dissertação de Mestrado Departamento de Letras, Pontifícia Universidade Católica do Rio de Janeiro.

"Tudo significa, as coisas" é um estudo em texto e imagem a partir do conto $O$ recado do morro, uma das narrativas que compõem a obra Corpo de Baile, de Guimarães Rosa, 1956. O trabalho visa criar um campo de investigação a partir de um conjunto de objetos produzidos no âmbito da própria pesquisa ou preexistentes a ela. Além do próprio conto, esses objetos são: o documentário de média metragem seres, coisas, lugares, inspirado em $O$ recado do morro e filmado em Morro da Garça, Minas Gerais, lugar que serve de cenário à estória de Rosa; o experimento de escrita Tudo significa, as coisas, construído, predominantemente, com as falas extraídas do material bruto do filme; e as cadernetas de viagem de Guimarães Rosa, publicadas com o título A Boiada. Integram ainda o presente estudo, um “caderno de reflexões críticas”, um “caderno de notas relacionais” e um "caderno de trabalho". O objetivo da pesquisa é, através desses objetos, identificar, produzir e refletir sobre as relações - trânsitos, ressonâncias, articulações, dobras entre: fala e escrita; literário e não-literário; documental e ficcional; cinema e literatura, Eu e Outro.

\section{Palavras-chave}

"O recado do morro"; Guimarães Rosa; fala e escrita; documentário. 


\section{Abstract}

Macedo, Suzana Teixeira de; Coelho, Frederico de Oliveira (Advisor). Everything means; the things. Rio de Janeiro: 2017. 235 p. Dissertação de Mestrado - Departamento de Letras, Pontifícia Universidade Católica do Rio de Janeiro.

"Everything means, the things" is a text and image study based on the short story $O$ recado do morro, one of the component narratives of Corpo de Baile (1956) by Guimarães Rosa. This work aims to create a field of research from a set of objects, some preexisting and some produced within the framework of the study itself. In addition to the short story, these objects are: the documentary seres, coisas, lugares, inspired by $O$ recado do morro and shot in the municipality of Morro da Garça, Minas Gerais, the original setting of Rosa's tale; the writing experiment Tudo significa, as coisas, constructed predominantly of lines extracted from the documentary's raw footage; and the travel notebooks of Guimarães Rosa, published under the title $A$ Boiada. The present study also includes: a "critical reflections notebook", a "relational notebook" and a "workbook". Through these objects, this study aims to identify, produce and reflect on relations - transits, resonances, liaisons, folds - between the spoken and written word; the literary and the nonliterary; documentary and fictional; cinema and literature; the Self and the Other.

\section{Keywords}

"O recado do morro"; Guimarães Rosa; spoken and written word; documentary. 


\section{Sumário}

$\begin{array}{ll}\text { 1. Caderno Zero } & 9\end{array}$

$\begin{array}{ll}1.1 \text { Conteúdo } & 10\end{array}$

$\begin{array}{ll}\text { 1.2 Modo de usar } & 11\end{array}$

1.3 Introdução 12

2. Caderno Um: Tudo significa, as coisas 16

3. Caderno Dois: Considerações Críticas 42

3.10 filme $\quad 44$

3.2. O Mesmo, o Outro 53

3.3. Doidos e Não-doidos $\quad 59$

3.4. Listas, séries, conjuntos 65

3.5. Falar e ouvir, ler e escrever 69

$\begin{array}{ll}\text { 3.6. O experimento de escrita } & 79\end{array}$

$\begin{array}{ll}\text { 3.7. Ato de leitura } & 87\end{array}$

4. Caderno Três: Notas Relacionais 98

5. Caderno Quatro: Tudo significa, as coisas - o avesso 200

6. Referências bibliográficas 227 
0

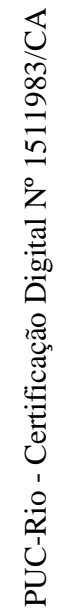




\section{CONTEÚDO:}

1 filme documental de média-metragem (45')

4 cadernos

O filme: seres, coisas, lugares

Um diálogo com "O recado do morro", uma das narrativas que integram a obra Corpo de Baile, de Guimarães Rosa, 1956, filmado em Morro da Garça, Minas Gerais, região em que se passa a estória.

O caderno 1: "Tudo significa, as coisas"

Um experimento de escrita construído, predominantemente, com as falas dos moradores de Morro da Garça extraídas do material bruto do filme. Esse texto é composto, ainda, em menor proporção, de trechos retirados do conto e trechos escritos por mim, misturados sem distinção.

O caderno 2: Considerações criticas

Considerações críticas relativas ao filme seres, coisas, lugares, ao texto "Tudo significa, as coisas" e ao trabalho como um todo.

O caderno 3: Notas relacionais

Apresenta, lado a lado, em colunas verticais, fragmentos extraídos das seguintes fontes: o texto "Tudo significa, as coisas", as cadernetas de viagem de Guimarães Rosa publicadas com o título A Boiada; o conto "O recado do Morro"; o documentário seres, coisas, lugares; além de "notas avulsas de uma viagem ao sertão" e outras citações.

O caderno 4: "Tudo significa, as coisas" - o avesso

Uma versão colorida e legendada do experimento de escrita que evidencia, parcialmente, o processo de montagem do texto, deixando ver as emendas no seu interior e revelando a procedência de cada frase. 


\section{MODO DE USAR}

1. A leitura de "O recado do morro" não é pré-requisito para a leitura deste trabalho.

2. A versão impressa deste estudo é acompanhada de um dvd e, para a versão eletrônica, o acesso ao filme se dá através do link: https://vimeo.com/167570024 com a senha: serescoisaslugares.

3. O caderno 2 deve ser lido, preferencialmente, depois da leitura do caderno 1 e/ou depois de assistido o filme.

4. O caderno 4 não deve ser lido antes do caderno 1

5. O caderno 1 - e, consequentemente, o caderno 4 - não respeitam a norma culta da Língua Portuguesa.

6. O Caderno 3 - Notas Relacionais - foi concebido para ser sido em página dupla. A versão impressa trará o texto na frente e no verso das páginas, enquanto a versão eletrônica precisará ser lida a $90 \%$ da tela para que se possa visualizar a página dupla.

6.1 As três primeiras colunas do Caderno 3 estão intituladas, genericamente: o texto, as cadernetas, o conto, e correspondem, respectivamente, a: o experimento de escrita "Tudo significa, as coisas"; as cadernetas de viagem de Guimarães Rosa publicadas com o título A Boiada; o conto "O recado do Morro".

6.2 A coluna "notas avulsas" compreende trechos de uma caderneta de viagem produzida a posteriori e batizada de acordo com a expressão que aparece como subtítulo do filme: "notas avulsas de uma viagem ao sertão".

6.3 A coluna "outros" abriga fragmentos de prosa e poesia, ficção e não ficção, verbetes de enciclopédia e outros.

6.4 A sexta coluna - "o filme" - abriga trechos do documentário não contemplados no experimento de escrita e trechos do material bruto da filmagem não contemplados no filme.

6.5 O uso de negrito no interior das colunas do Caderno 3 é equivalente a um link num hipertexto.

7. O uso, no segundo caderno, da primeira pessoa do plural, se deve menos à praxe do meio acadêmico e mais ao fato de que, neste trabalho, eu, quase nunca, sou apenas eu. 


\section{INTRODUÇÃO}

Agora, entre meu ser e o ser alheio a linha de fronteira se rompeu.

Waly Salomão

Este trabalho poder ser pensado, talvez, como uma câmara de ecos na qual ressoam vozes vindas de tempos e espaços distantes e diversos. São as vozes de Zito e Manuelzão, entre tantos outros sertanejos, que ecoam nas cadernetas de Guimarães Rosa, que ecoam em "O recado do morro", que ecoa, por sua vez, no filme documental, que ecoa, por fim, no experimento de escrita, onde ecoam, ainda, as vozes dos atuais moradores de Morro da Garça, no interior das quais ecoam tantas outras vozes.

A configuração final do estudo e as estratégias utilizadas não foram previstos de antemão. Método, objeto e objetivos da pesquisa não preexistem a ela, mas foram se constituindo ao longo do processo. Em "Sobre a escova e a dúvida", o quarto prefácio de Tutaméia, encontramos, casualmente, a melhor descrição desse processo: "Dadas vezes, a chance de topar, sem busca, pessoas, coisas e informações urgentemente necessárias." O nome disso, segundo nos informa a nota de pé de página, seria “soroptimícia” ou, em inglês, serendipity: "Feliz neologismo cunhado por Horace Walpole para designar a faculdade de fazer por acaso afortunadas e inesperadas 'descobertas',". 1

Os autores citados e consultados, um grupo numeroso e eclético que inclui - em pé de igualdade - teóricos, poetas e ficcionistas, foram sendo convocados, no desenrolar da pesquisa, para iluminar a abordagem das questões despertadas pelo próprio trabalho, não estando também decididos previamente. $\mathrm{O}$ fato de "O recado do morro" ser o ponto de partida do estudo não significa, ainda, que o conto ${ }^{2}$ seja o

\footnotetext{
${ }^{1}$ ROSA, 1985, P.174

2 Ao longo de todo o estudo "O recado do morro" é referido como conto. A rigor, tratar-se-ia de uma novela, embora a classificação das estórias de Corpo de baile seja um capítulo à parte. Optouse pelo termo conto por nos parecer de maior comunicabilidade.
} 
objeto central da pesquisa. A ficção foi nossa realidade primeira, o primeiro contato com aquele lugar tornado 'mítico' pela literatura. A leitura do conto foi propulsora de um movimento que produziu novos movimentos e desdobramentos aos quais este trabalho busca dar forma. Assim, tudo, ou quase tudo, o que aqui será dito são elaborações posteriores, retrospectivas, "rastreadas pelo avesso".

Podemos pensar, então, retrospectivamente, que todos os esforços empreendidos nesta pesquisa respondem a um mesmo desejo: o de experimentar o conhecimento não apenas como uma reflexão sobre o desconhecido, mas como um fazer, uma experiência, uma interação. O desejo de colocar imaginação, intuição e emoção a serviço da construção do conhecimento, de onde são frequentemente alijadas. "Quanto mais afetos permitirmos falar sobre uma coisa, quanto mais olhos, diferentes olhos, soubermos utilizar para essa coisa, tanto mais completo será nosso "conceito" dela, nossa "objetividade". ${ }^{3}$ Em defesa do mesmo princípio (a intromissão da subjetividade na construção do conhecimento), por outra via, poderíamos evocar, através de Eduardo Viveiros de Castro, as epistemologias indígenas, segundo as quais "quanto mais intencionalidade se atribui ao objeto, mais se o conhece". ${ }^{4}$ E, ao invés de considerar essa intromissão como obstáculo, considerá-la, além de inevitável - como, de fato, é - bem-vinda.

Nesse sentido, preocupado em como pensar e não apenas com o quê pensar, este trabalho, cuja forma deve ser entendida como inseparável de seu conteúdo, pretende, em certa medida, interrogar os próprios modos de construção do conhecimento.

O experimento de escrita intitulado "Tudo significa, as coisas" - daqui em diante, referido simplesmente como texto - é o produto central da pesquisa. Entretanto, isto não significa que o texto seja o lugar de onde tudo parte e para onde tudo converge. Texto, filme e conto contém e estão contidos, uns nos outros, de um modo, muitas vezes, indiscernível. Cada uma das peças desse conjunto é, portanto, uma multiplicidade. Uma multiplicidade que se conecta a outras multiplicidades. Texto, filme e conto figuram na dissertação como objetos pensantes, objetos a serem pensados em si mesmos, e objetos que circunscrevem um campo de pensamento. Não se trata, apenas, pois, de uma pesquisa que constrói seu próprio objeto, mas de

\footnotetext{
${ }^{3}$ NIETZSCHE.1998: 109

${ }^{4}$ VIVEIROS DE CASTRO. 2007, p.42
} 
um objeto que ocupa, na pesquisa, um outro lugar - um lugar que é fim e meio, simultaneamente.

As reflexões que serão desenvolvidas no trabalho apontam em muitas direções e não visam a nenhuma totalização, o que seria, neste caso, impossível e indesejável. Impossível, porque as relações possíveis entre os objetos em jogo tendem a ser infinitas. E indesejável porque o objetivo da pesquisa é, justamente, produzir um conjunto aberto e inacabado, multiplicando as relações - conexões, trânsitos, ressonâncias, articulações, dobras - entre o oral e o escrito, o literário e o não-literário, o documental e o ficcional, o cinema e a literatura, o Eu e o Outro,

A criação dessa rede de relações enseja um movimento especulativo que acontece antes no plano horizontal que no plano vertical. Também por este motivo, o trabalho não busca o aprofundamento minucioso das questões levantadas que, além disso, envolvem diversas disciplinas como linguística, história e etnografia.

Uma questão, entretanto, parece atravessar todas as outras e refere-se à própria natureza do ficcional e seu duplo caráter que mistura, inevitavelmente, o empírico com o imaginado. Embora não seja nossa intenção tematizar as complexas relações entre o real e o ficcional - e sim observar como elas operam no interior do trabalho - talvez seja oportuno lembrar que esses termos são tomados, aqui, como termos não opositivos, não excludentes e não identificados, respectivamente, com verdadeiro e falso. Como se sabe, a palavra fictio, de onde deriva ficção, designa o gesto de modelar, construir, dar forma.

\begin{abstract}
Não se escrevem ficções para esquivar-se, por imaturidade ou irresponsabilidade, dos rigores que o tratamento da "verdade" exige, mas justamente para pôr em evidência o caráter complexo da situação, caráter complexo para o qual o tratamento limitado ao verificável implica uma redução abusiva e um empobrecimento. Ao dar um salto para o inverificável, a ficção multiplica ao infinito as possibilidades de tratamento. (SAER.2009)
\end{abstract}

O real, por outro lado, assim como entendemos, não se resume à dimensão material e empírica da existência, mas constitui-se como um campo de forças atravessado por intensidades, virtualidades, durações. O real é, pois, algo que encontra-se em permanente processo de diferenciação - de si mesmo - e que não se deixa objetivar completamente. "O real precisa ser ficcionado para ser 
pensado". Desse modo, qualquer tentativa de extrair estruturas inteligíveis do caos informe que é o real, consiste, invariavelmente, em uma ficção.

A exploração dos limites entre o ficcional e o documental - e suas modulações: falso e verdadeiro, real e irreal, natural e sobrenatural - atravessam o conjunto do trabalho, em diferentes planos, desde o enredo do conto, que fala de um recado que teria sido emitido pelo morro, até o tratamento dado pelo filme ao gênero documental.

Longe de querer capturar o real com a maior objetividade possível, a proposta do filme era valer-se do material documental para criar uma narrativa híbrida, na fronteira com a ficção. No filme, opera-se, então, uma dupla inversão: a ficção é tomada como uma espécie de base teórica para o documentário que, por sua vez, é concebido como produto da imaginação. Tomar o conto de Guimarães Rosa como uma espécie de base teórica para o documentário significa reconhecer, na ficção literária, um modo de conhecimento ou "um meio de descoberta e de esforço, não para expressar o que sabemos, mas para sentir o que não sabemos" ${ }^{6}$ Também no experimento de escrita, a ficcionalidade do texto é decorrente da estratégia inerente à sua construção, e não da natureza de sua matéria-prima.

No Caderno de Notas Relacionais, que integra o conjunto do trabalho, podemos ver, sob a forma de fragmentos dispostos na vertical, a rede de relações formada entre prototextos (as cadernetas e as 'notas avulsas'), hipotextos e hipertextos. Os espaços deixados em branco são a imagem-símbolo da incompletude do trabalho, no seu todo, e um convite a que o leitor, se assim o desejar, preencha e crie suas próprias relações.

\footnotetext{
5 RANCIÈRE. 2009

${ }^{6}$ BLANCHOT, 1997, p. 81.
} 
1

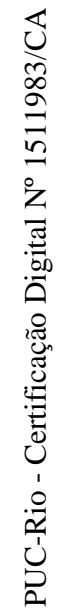


TUDO SIGNIFICA, AS COISAS 
Com as vozes de:

Antonio Rodrigues Lopes Carlos Alberto Santos Sousa Carlos Roberto Diniz Conceição Alves da Rocha Geraldo Magela Lucio Geraldo Nonato da Cruz João Guimarães Rosa Mario Magdaleno de Oliveira Suzana Teixeira de Macedo Washington Gomes de Avelar 
Método deste trabalho: montagem literária. Não tenho nada a dizer. Somente a mostrar. Não surrupiei coisas valiosas, nem me apropriei de formulações espirituosas. Porém, os farrapos, os resíduos: não quero inventariá-los, e sim fazerlhes justiça da única maneira possível: utilizando-os. 
- Eles eram uns 8 companheiros. E mais a peãozada. Os dois velhos parece que eram os capatazes, né? Esses dois é que comandavam a turma toda. Onde eles gritassem que era pra parar, até o guia lá adiante tinha que parar com o gado. $\mathrm{O}$ gado deles era só gado macho, gado novo, gado esperto... Mas tava tudo cansado, já, com a orelha pendurada, de tanto andar. Aí eles chegaram com a boiada e pousaram lá nessa fazenda onde nós tava, lá, no Catatau, no Geraisão, lá. Nessa época eu era menino de escola, ainda. Chegaram lá com a peãozada, um gadão, aterrissaram lá, pousaram lá... Aí essas meninas faladeiras foram lá receber eles... E eles gostaram!... Eles eram gente estranha e aceitaram elas de bom coração. Aah! Aí elas tomaram conta que nunca mais pararam de conversar... E eu só olhava, assim, de longe, e essas meninas grudadas lá. Se nós não dana com elas, nem dormir elas não iam, lá pra dentro. Ficavam lá, quentando fogo, a noite toda, mais esses homens. E quanto mais elas falavam, mais eles gostavam também. Eu já tinha ido lá conversar com eles. Um menino lá, companheiro nosso, levou até milho pro homem dar pra mula dele. Cada espigão! Descascava e quebrava no meio e dava o bicho pra comer com sabugo e tudo. E nós lá, olhando e rindo. Aí fizeram um fogo. E ele com uma cadernetinha, assim, em riba da perna, assim, perguntando o nome de todo mundo e escrevendo. O nome delas foi os primeiros. Depois foi buscar nós. Depois buscar papai. Depois buscar os meninos lá da Diva. E foi escrevendo o nome de tudo! E esse povo era olhando os bichos também. De manhã cedo, quando nós ia pro curral beber leite, eles iam lá pra olhar o quê que nós tava fazendo. Beber leite cru tirado direto da vaca e bebendo. Aí o menino falou: - "Vocês vão aceitar leite? Eu vou buscar o copo e o Senhor bebe!" E ele: - "Não, o leite é muito bom, mas nós não vamos aceitar, não. Beber leite, não.” E as vaca asseadinha, limpinha... Não tinha carrapato, não tinha berne, não tinha nenhuma perebinha, nada. Eles olharam, olharam, mas beber o leite não queriam, não. Aí no outro dia ele falou: “Ó, Carnelygia, você, mais a Diva, nós tamo indo embora, mas tamo levando aqui essa escrita, o nome desse povo todo aqui,! Tá tudo escrito aqui pra mó de fazer um livro! Do lugar onde nós andamos." Aí eu perguntei onde é que eles iam passar: "Nós vamos sair por esse Gerais aí afora... Na Serra das Cabras nós vamos subir; na Serra do Cruzeiro nós vamos descer; nós vamos pousar lá pro lado do Riacho das Vacas... E vamos descer por aí abaixo, vamos caçar Bicudo por aí abaixo...” E 
esse povo andando, na lida... Esse povo andou foi um bocado nesse mundo! O Manuelzão e o Guimarães Rosa. Agora eu não sei é onde eles foram parar...

\author{
Em cima daquele morro \\ Ah, morena! \\ Eu vi o mutum gemer, oi-iá \\ Eu vi o mutum gemer \\ Ah, morena! \\ Meu corpo todo tremer, ai, ah!
}

- Existe Deus, também. Existe. Existe o céu, existe Deus morando lá, existe o capeta, também, existe o inferno, também. Não precisa ninguém duvidar, não, que tem de tudo, tem. Tem hora que a felicidade parece que não é toda hora não. Tem hora que a gente tá alegrezinho, aí, de repente, topa um trem de mal jeito... Aí, quando vê, a gente tem que enfezar depressa demais. Então, tem esse trecho também. Tem as partes boas e tem as partes ruins. Tem umas horas que a gente não é muito feliz mesmo não. Se a felicidade fosse direto, ninguém acreditava que tinha o capeta!

\author{
Lá vai a Garça voando \\ Com a pena que Deus lhe deu \\ Penando pena por pena \\ Mais pena padeço eu
}

- Eu fui nascido lá pros lados dos Gerais, lá. Lá só tinha era vereda, era campina, era só gorgulho de pedra e capim barba-de-bode... Esse trem era o Gerais. Cerradinho baixo, raso. É o Geraisão. Areia... Eu tava com um ano e dois meses quando começou a vida ruim. Deus levou mamãe e eu fiquei com um ano e dois meses. Deus não quis levar eu não. Tudo de ruim no mundo aconteceu comigo. Que menino sem mãe é só de sofrer. Eu fiquei doente até inteirar 2 anos. Diz que os mosquitos andavam dentro dos meus olhos que eu nem mexia. Quando eu dei conta de levantar, um avô pegou eu, levou eu, criou eu. Então, um dia tava muito bom, outro dia tava pior, outro dia tava mais ou menos... E quebra a orelha de um lado, quebra a cara de outro, e lá vai vivendo... Eu era um menino bom da ideia, um 
menino bom de mexida, inteligentezinho... Um bichinho macho, bem quentezinho, bem bonzinho... Até que papai carregou eu de lá. Tirou eu do céu e levou eu pro inferno. Essa bocaina era um lugar feio, bravo. Era serra dum lado, serra do outro e um córrego beirando a serra. Na outra serra era só grotão feio e bicho perigoso e tudo o que era trem feio. Tinha onça, tinha tudo que era qualidade de cobra braba, tinha tudo quanto era bicho ruim. E papai largava nós lá. E nós era só dois. Arroz a gente tinha que socar no pilão, lenha a gente tinha que buscar no mato, água a gente tinha que buscar também. Eu tinha uns 10, 12 anos, ia pra escola, caminhava uma, duas léguas pra chegar na escola, todo dia, então eu sofria muito. E a vida foi continuando. E papai judiando de mim e eu sofrendo, sofrendo...Ah! Aí eu embrabeci. Embrabeci mesmo. Embrabeci de um jeito que eu não prestei mais. Virei burro bravo, endureci o queixo, o pescoço... Em vez de aprender ler, eu aprendi foi brigar. Aí quando eu aprendi a brigar eu achei melhor. Eu falei: - "Eu já sofri que chegue. Agora eu vou é cacetar um bocado de trem também.” E eu fiquei igual aqueles galinho inchado, redondozinho. E toda hora eu queria uma briga. Topava mesmo. Então eu continuei a vida. Trabalhava de enxada, plantando roça eu trabalhava com lata de matar lagarta, de bater veneno em planta - eu entrei sempre dentro dos perigos... Trabalhei no curral tirando leite. Trabalhei em bateção de pasto. Carreei lenha pra carvoeira, trabalhei de peão... Depois quando eu fui trabalhar de peão, quando eu virei bicho doido, aí eu achei gostoso! Agora eu achei gostosa a vida! Agora eu adorei! Era só montar bicho grande e gordo e bom de sela! E pular alto! Ah! Eu adorava! Essa época eu fazia sucesso com as moças e peguei um dinheiro bom também. Ah, eu tinha mais prazer era quando as moças chegavam perto pra ver eu montar. Ô vida minha! Não tinha o direito de pegar na mão de ninguém. Só sacudia a mão pra elas e o bicho tava até urrando debaixo de mim! Eu adorava! Eu fazia tudo na vida pra ver o trem sair gemendo comigo. Batia as esporas nos quiuquiu do bicho e o trem pulava alto demais! Tinha vez que rebentava o arreio todo. Jogava o arreio e eu longe. Vixe, Maria! Esse é bom! Era um cavalo bonito, viu? Um cabelo grande! Não era bom de sela, não, mas era bonito, grande, gordo! Pulava alto! Ah! Aquela casou com um nego feio e doido. Eu falei: - Diabo, se eu sei que era pra desperdiçar com um excomungado que não prestava pra nada, eu tinha descido do cavalo e proposto a ela um namoro, né? Mas ela era bonita demais! Eu fiquei assombradinhozinho. Eu amansei esse cavalo com tanto prazer, que eu falei: eu vou amansar esse cavalo que um dia eu ainda vou encontrar aquela menina 
em riba desse castanhão! Depois ele amansou, ficou um menino manso, ficou igual uma cera... Eu trabalhava o dia todo e quando chegava de noite, pegava ele e chutava no mundo. Montava em pelo, cortava no couro e corria demais! Aí quando eu voltava, papai falava: - "Esse cavalo não presta. Cavalo ruim. Nós vamos vender esse cavalo!” E eu: - "Vende sua égua, pai! Não vai vender meu cavalo, não.” “Que diabo que esse cavalo tá caçando aqui?" - "Ô, pai, deixa o cavalo quieto, sô! Esse cavalo gosta de mim demais." - "Vou pôr ele aqui dentro pra ele viciar entrar aqui? Ponho não! E o dia que você não tiver?" Aí eu falei: - "O dia que não tiver eu, não tem ele também. Nós dois não separa, não. Nós é junto.”

- Antigamente, aqui nesse Morro, ninguém tinha sossego, não. Que esse povo aqui era brigador demais. Eles matavam um, cedo, e amarravam um no pau pra matar de tarde. Tinha vez que matavam era dois de uma vez. Aqui tinha uns homens que achavam que eles eram os donos do mundo. Lá na fazenda do Saco Preto, tem lá até hoje o quartinho que eles batiam nos escravos. Mas isso era antigamente. Naquele tempo, ali, depois daquele córguinho, tinha um engenho de pau tocado a boi. De noite, a gente ia fazer farinha. Quando dava de madrugada, a gente ia pro curral tirar leite. Aí tinha uma desnatadeira tocada a mão pra separar a gordura do leite. Nisso punha nas latas de creme - que eles falavam creme - pra levar pra Curvelo que lá tinha uma fábrica de manteiga._Naquela época, não era luz elétrica, não. Era querosene. Quando nós ia deitar, que apagava a lamparina, era uma coisa de louco o barulho que aquela assombração fazia. Derrubava cadeira, derrubava armário, era um trem fora de série essa assombração. Só vendo! O tanto de coisa que aparecia de barulho! Aí eu sentia assim chegando o cavaleiro, fazendo tchap, tchap, tchap... no rasteio molhado, nos estercos... Aí eu levantava, abria a janela, e não via ninguém. Nada chegava._O primeiro aparelho que chegou aqui foi um rádio antigo. Aí todo mundo gostava de escutar as músicas. Mas a gente tinha vergonha de ir na casa do fazendeiro, então a gente ficava debaixo dum pau, assim, escutando, de longe. Nessa época não existia dinheiro. Ninguém pagava o outro, não. Era troca de dia. Vamos sipor, assim: o amigo tinha uma roça. Aí o povo ia lá pra roça dele e, quando terminava a roça dele, já ia pra roça do outro. Outra hora trocava o dia por mantimento, um toucinho, alguma coisa assim._A gente ia pra Curvelo, no carro de boi - punha 8 bois num carro, rodeia de pau - e ia de pé, guiando os bois. Levava 
lenha pra trocar - que lá também não tinha gás e o pessoal todo comprava lenha levava lenha e trazia querosene, sal, açúcar, o que precisasse. Porque arroz a gente plantava, milho, as outras coisas a gente tinha aqui. De primeiro, todo mundo colhia pra despesa. Eu, pelo menos, eu não comprava arroz, não comprava feijão, não comprava óleo, que eu engordava porco... Era desse jeito, antigamente. Era assim que rodava. Eu já tomei conta de 200 pessoas, já, no serviço. Gente de todo tipo que você pensar. Eram presos que eles juntavam lá em Januária e traziam pra cá. Eram dois empreiteiros. Eles iam na cadeia, tiravam os presos de lá, e traziam pra cá pra trabalhar. Ficavam aí, assim, 45 dias, e iam embora. Pagar mesmo eles num pagavam é nada. Só o comer. Tipo escravo, né? Essa era a vida, de antes. O Morro? O Morro eu subia lá era todo domingo. Eu gostava de caçar. Tinha muito tatu, tinha paca, lontra, veado, catingueiro, capivara, raposão...Tinha muita coisa lá. Tamanduá. Suçuarana. Mas suçuarana não faz mal a ninguém, não. Ela num guenta um grito! Se você gritar, ela corre. Ela casca fora. Ela não encara, não.

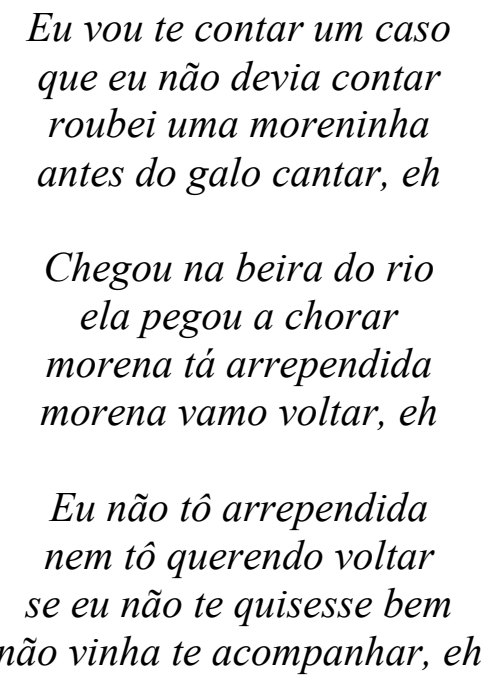

- Eu tinha uma namorada boniiiita! Foi eu mais ela foi os dois primeiros que correram a mão no pêlo um do outro. Vixe! Pra mim era um dengo essa menina! Maria de Lourdes. Era uma cepa de menina boa! Era um trem do outro mundo ela. Era a coisa mais linda que eu achava na vida! Uma morena dos olhos meio esverdeados, cor de papagaio, um cabelo preto desse cumprimento, forte... Pra mim ela tinha tudo pra ser uma mulher boa! Eita! Nós ia casar. Nós era um casalzinho 
muito arrumadinho. A vó dela gostava demais de mim. Já papai pulava pra trás. Virava bicho. Que ele não queria mesmo. Papai, pra casar com nós tinha que descer do céu por descuido, né? - “Ô pai, de lá pra cá Deus não vai mandar, não. O senhor tá enganado com esse negócio. Eu vou arrumar uma mulher é pra mim, não é pra você, não. Ela combinando comigo, eu quero.” Aí com uns 18, 19 anos nós tava namorando direitinho. Desde os 14 em diante nós era namorado. Com 22 anos nós ia casar mesmo. Eu marquei com ela: - "Olha, espera eu sair desses 21 anos - que até os 21 anos eu tenho quem me mande - espera eu sair dele, que nós vamos casar. Se nós não casar aqui, nós foge. Nós vamos fugir e casar longe." Aaah! Aí aconteceu um fato muito triste. Essa menina, eu fiquei sem ela. Não deu certo nós casar. Quando foi um dia, na hora que eu cheguei lá, parece até que eu tava adivinhando - a avó dela falou comigo que não me entregava ela mais não: "Entrego você ela mais não. Não tá do jeito que eu queria, mais. E nem do jeito que você sabe que ela era." Mas eu ainda queria ela assim mesmo. A menina tinha sido...Um sujeito desencaminhou a vida dela, tirou ela do trilho... A velha foi e não quis me entregar ela mais não. Ninguém falou nada um com o outro... E pronto. $\mathrm{O}$ sofrimento foi pesado. A barra ruim. Aí eu falei: eu não quero mais vida com mulher, não. Eu quero agora é sozinho. Namorada eu não quis nunca mais arrumar outra. Todas que mexiam comigo eu falava: - "Meu coração tem uma porteira que já foi fechada e não vai abrir mais não. Cês podem sair fora de mim que eu não quero namorar com você, eu não quero namorar com fulana, eu não quero namorar com sicrana, agora eu vou partir é pra encrenca. Mulher, não! Pode sumir de mim.” Dez anos eu fiquei sem esquecer dela um momento. Até dormindo eu tava vendo ela. Nada me servia. Dormia pouco. Trabalhava de domingo a domingo, sofrendo, amolado... E nada prestou, desse dia em diante... Nunca mais eu prestei também. Nada deu certo pra mim mais. Nada se encaminhou direitinho pra mim. Nada enlerou no jeito pra mim mais. Foi só ruim, só ruim, só ruim. Só o que eu desejava fazer e não fiz era casar, ter uma família, trabalhar juntinho... Mas isso não deu. Agora eu já corro do pedaço.

Saudade daquela moça, ai morena

Tá querendo me matar, oiá

Deixa pra amanhã bem cedo, ai morena

Vai matando devagar, oiá 
- Eu nasci na Capivara-de-Baixo. Lá é município de Corinto. Mas já tem pra onze anos que eu vivo aqui no Morro. Eu fui assim muito namorista, assim, nos meus tempos de boemia, sabe? As moças parece que gostavam demais de mim. Se a gente falar, parece que o povo nem vai acreditar. Eu namorei 153 namoradas. Mulher solteira e moça, sabe? Vai contar, ninguém acredita. Tinha noite que eu deitava na cama, e ia contar quantas namoradas, em tal lugar, tal lugar... Isso acontecia dessas namoradas até brigar umas com as outras e chegava até o padre ir lá separar a briga delas. Enquanto elas tavam brigando, eu saía e ia pra casa de outra, que eu tinha eram muitas, né? Aquilo era uma disputa das moças comigo. É uma coisa que ninguém acredita, é uma coisa que eu devia ter anotado num caderno. Aí eu pensei: Ah, eu vou casar. E muitas moças ricas me propunham casamento. Eu tinha uma malinha, lá, que era cheia de carta de namorada, me pedindo a mão em casamento. Chegavam as cartas molhadas de choro. Mas eu pensava assim: eu sou pobre, eu não vou casar com moça rica, não, né? Então eu vou caçar uma igual a mim que assim ela não pode se queixar. Se ela for se queixar eu digo: eu casei com você porque você era igual a mim, então nós dois tá bom de viver junto. Essa que eu casei chamava Teresa. As outras chamavam Carmen, era Maria Lina, era Áurea Lúcia... Tinha a tal Joaquina, a Neusa, a Diva ... É tanto que o povo ficava até com inveja de mim. Agora eu sou uma pessoa que eu quero só amizade com os outros. Não quero briga com ninguém. Não quero mal querência com ninguém. A gente já passou dos 60, não é? Então a gente tem que caçar é união com todo mundo. Por que a gente vai até os 60 , mais ou menos, e aí já começa a voltar pra trás, a idade. Vai enfraquecendo, vai perdendo a força, vai se tornando criança de novo.

Valha-me Nossa Senhora

Dê juizo a quem não tem

Dê juízo àquela ingrata

Pra tornar me querer bem

- Eu fui nascido e criado aqui no Morro da Garça mesmo. E, agora, Deus me trouxe de volta aqui pra minha terra. Esse barraco, aqui, foi meu pai que fez, tá vendo? Meu pai era um homem muito bom de coração. Então ele fez de barro, assim. Eu 
não quero desmanchar essa casa nunca na minha vida porque foi aqui que ele me gerou. Eu fui gerado aqui dentro. Eu não quero desmanchar essa casa nunca. Então agora eu tô reformando ela. Minha mãe, meu pai comprou isso aqui batendo foice, machado, roçando fazenda, cozinhando carvão. E criou aqui dentro a nossa família. Eu quero colocar a foto desse barraco num quadro, tá vendo? Eu quero colocar aquela parede aqui dentro, tá vendo? Aqui pra mim é melhor do que qualquer lugar do mundo! Aqui pra mim é a mesma coisa que estar numa mansão, rapaz! Eu cresci aqui. $\mathrm{O}$ meu quarto era esse aqui, mais os meninos, quando nós era novo. $\mathrm{O}$ meu pai suicidou. Morreu aqui, ó. Ele amarrou a corda aqui, ó, e suicidou. No pescoço. Em cima da cama. A cama de casal da minha mãe ficava aqui. Na época eu tinha 9 anos de idade. Olha, eu vou falar pra você, eu não tenho sabedoria de entender essas coisas, não, sabe? Já perguntei pra minha mãe, se era problema de relação, falta de amor... Ela diz que ele era muito ignorante, batia nela, entendeu? A vida aqui era muito difícil, eles trabalhavam em carvoeiro, cozinhando carvão...Então, ele - diz que era grosso, esses homem grosso, que não tem senso... E aí eu acho que aconteceu essas coisas aí, na briga deles, novo, da minha mãe mais ele, e ele acabou suicidando; problema deles dois. Mas ela não me falou. Já perguntei bastante, mas ela não me falou. Eu acho que a cabeça dele era quase igual a minha, sabe? Mas ele era muito coração bom, então eu acho que ele num guentou. O que eu posso imaginar, ou foi problema com a minha mãe, ou ele num guentou ver as coisa aqui. Porque o diabo tem usado muito as pessoas aqui nessa terra, já há 40 anos, e aí Deus tem dado a eles o castigo. Porque a ira de Deus fica por cima da cabeça da gente. Assim como ele dá as bençãos pra você, ele também permite que as coisas vem acontecer com você. As coisas ruins. Por causa que o Deus que dá as coisas boas é o mesmo Deus que permite que as coisas ruins aconteçam. É o mesmo Deus. Porque eu, eu tô na mão de Deus. Você tá na mão de Deus. Quando você tá no seu carro, você tá na mão de Deus. Quando você tá dormindo, Deus tá te guardando. Quando você tá alimentando, ele é que tá te cuidando. Deus é que tá alimentando. Você tá vendo essa terra vermelha, aqui? Tudo o que você planta dá! Se você jogar uma semente de feijão, ela nasce! Sem você fazer nada, sem cultivar. Só Deus é que faz ela germinar. Quando você pisca e abre o olho, Ele é que tá permitindo você abrir o olho. Ele é que move você. E quando Deus fala: você não vai viver mais, Ele vai e apaga o seu espírito. Morreu. Aonde fala: morreu. Foi Deus que trouxe você aqui e você não sabe. Seus passos são dirigidos por Ele. O espírito do homem 
é na mão de Deus! A profissão suas, que Deus deu a vocês, são poucas pessoas que falam que foi Deus que deu. Como os artistas - ator, atriz - todos foram Deus que escolheu pra eles a profissão. É Deus que escolhe pra nós. É Ele que dirige, não é? Não é a gente que escolhe. Se a gente escolhesse, todo mundo era rico! Ele é que me dá a minha voz. Não é eu que falo o que eu falo. Ele é que dirige as minhas palavras. Não tem como eu querer ser você. Eu sou eu, você é você, não é? Mas vai sofrer o que eu sofri... Eu dormi no mato, eu comi do lixo...Eu fiquei aqui sem comida, fiquei sem água... Mas eu não abalei co'essas coisas, não. Deus ia cuidando de mim, co'as frutas... Dava uma manga, dava um caju... E aí ele foi me_ensinando a viver co'as poucas coisa. Fiquei aqui até sem água pra fazer a comida. Tinha comida e não tinha água pra cozinhar, às vezes! E o povo, eu pedi à menina, ali, e eles brigaram comigo pra me dar água. Me negaram água! É por causa da minha voz. Eles não conseguem ouvir a minha voz. Vinde, povo: senvergonhas, pecadores, homens e mulheres, todos. Todos eu amo, vim por vosso serviço, Deus enviou por mim, ele quer o vosso remimento. Porque o diabo, ele vem pra matar, roubar e destruir. Trazer tristeza, miséria. Então Deus me trouxe pra fazer o contrário, trazer o bem, a paz, a fartura. Então ele me odeia, né? O diabo. Ele quer me ver morto. Por causa que eu sou o ungido, o profeta, o escolhido. Tá vendo a minha voz? É a Voz e o Verbo... É a Voz e o Verbo... Arreúnam, todos, e me escutem, que o fim do mundo está pendurando! Olha o aviso: evém o fim do mundo, em fôgo, fôgo e fôgo!

- Cadê que o mundo acaba! Acaba pra quem morre! O pessoal falou que ia acabar no dia 21. Aí eu levantei cedo, palpei eu, e falei: -“Ops, minha mãe, tô vivo!” Olhei pra riba e admirei: - "Olha o sol aí, minha gente!"

- Eu não acreditei porque eu sei que o mundo não vai acabar. Mas aqui teve gente que tava até adoecendo de medo. Teve gente que nem na rua saiu.

- Teve gente que achou que acabava. Teve gente que vendeu lá muita coisa com medo de acabar.

- Às almas, meus irmãos! O fim do mundo, mesmo, já começou, por longas terras. E vem vindo...Olha os prazos! Vamos rezar, vamos esquentar, vamos ser! 
- Desde que eu era menino, o povo fala que o mundo vai acabar. Agora veio essa noticia, de novo.

- Fim do mundo... Fim do mundo... O cão! Agora que eu estou tão rico... E aquele vem prenunciar o fim do mundo! Uma tana!...

- Acabou em água, uma vez, agora vai acabar em fôgo!

- Acabar? Posso dar meu juramento. Acaba nunca! Isso de mundo se acabar, de noite ou de dia, é invenção de gente pobre...

- Teve um sujeito que chegou lá na minha casa, aquele solão, e ele: - "Ô cumpadre, o mundo vai acabar, cumpadre! Não adianta a gente trabalhar que nós vamos morrer de fome, de sede, assado, cozido, torrado no sol!" Até chorar ele chorou. E eu rindo..."Deixa de ser bobo caboclinho!"

- O mundo já começou a se acabar, e vós semprando na safadeza, na goiosa! Olha o enquanto-é-tempo...

- Será que o mundo acaba?

- Eu tenho pra mim que vai acabar nós, o mundo não acaba, não. Enquanto tiver mulher ganhando menino, vaca tendo bezerrinho, eles dizem...que tiver dando flor, não precisa ter medo que o mundo não acaba, não...E nunca começou também não... teve sempre aí.

- Eu nunca lembrei que o mundo acaba, não.

- Que nada e não. Acabava nunca. Cá, se tivesse o mundo de se acabar, outros, de mais poder e estudo, era que antes haviam de obter sua notícia.

- O mundo acaba é pra quem morre. De vez em quando vai um. Depois vai um punhado. Uns morrem de trombada, outros morrem caído n'água, outros morrem de queda de avião... Bate um caminhão aí, tomba aí, capota aí... Pra esse o mundo acaba.

- O mundo não acaba, não. Tem escrito no catecismo: o mundo não teve princípio e nem terá fim. Esse mundo velho é muuuncho mundo! 
- Mas não tem a história de quando o mundo começou? Eles falam. Eu acredito. Igual o Brasil. Tem 1500 anos que o Brasil foi descoberto. Não é assim que eles falam? Vamos dizer que aqui não existia nada, por exemplo. Aí veio uma pessoa e adquiriu família. Adão e Eva, eles falam, mas a gente não pode saber. Eles falam que a minha vó - porque a gente não conheceu os parentes - foi pegada no laço. Existia gente que morava dentro d'água, tipo assim...Outros falam que a gente é descendente dos macacos. Que hoje falam isso. Então, não sei. Eu acho que, quando o Brasil foi descoberto, só tinha macaco aqui. E é desses macacos que nós viemos. Mas tinha também os índios, não é? Os índios já viviam aqui. Junto com os macacos. E aí quando os macacos se transformaram em homens, os índios também se transformaram em seres humanos. E era uma maravilha isso aqui, naquela época. Precisa ver. Era assim, era tudo floresta, tudo tipo aquele jardim do Éden. Já ouviu falar? Então. Deus não falou que era pra não comer da maçã? Não foi assim? Só que, aí, a Eva fícou ali, tentando o Adão: - "Só uma mordidinha, só uma provinha, ninguém vai nem notar...” E aí, ó. Deu no que deu. Depois disso, a vida do homem na Terra só fez decair. Mal tinha começado e já desandou tudo. E quando começa errado, já viu, né? Vai errado toda a vida. Ai de nós! Agora, o começo do mundo, eles falam que o mundo já acabou uma vez, não é? Não tem isso? Vai ver. A questão que eles falam da Arca de Noé. Já não existia, quando o mundo acabou? Não pegou um casal de cada bicho e colocou na Arca? Aí, tinha um casal de gente, que era Adão e Eva, um casal de cada bicho, cada passarinho... Ou isso é lenda? Depois que o mundo acabou, que o mundo secou, a Arca parou. Por isso eu benzo uma pessoa de arca caída através disso aí. Benzo. E cura na hora. Fala assim, ó, nove vezes: Arca de Noé andou, andou, que até encostou. Arca caída volta pro seu lugar. Você fala 9 vezes e reza uma reza que você sabe, uma reza que você goste. Pronto. Tá curado. Mas eu só benzo pra esse mal. Porque o que é que acontece? Quando você benze uma pessoa, o mal dela passa pra você. Então se você benze uma pessoa com mau-olhado, depois você tem que tomar um banho pra tirar aquilo do corpo, praquilo não ficar com você. Bom, mas mais antigamente ainda, o que aconteceu foi o seguinte: antes dos homens, existiam os macacos, e antes dos macacos, existiam os dinossauros. Na época dos dinossauros, eles eram os reis. Aí a Terra foi esfriando, esfriando, esfriando, até que congelou. Daí eles não güentaram. Quando aquela neve toda derreteu, não tinha mais nenhum dinossauro pra contar a história. Tem gente que não acredita. Que acha que dinossauro é assim, que nem dragão. 
Tipo bicho inventado: unicórnio, cavalo-marinho, esses bichos. É muita ignorância, não é? Mas, então. No inicio era o verbo. E Deus disse: Faça-se a luz. E a luz se fez. E Deus viu que a luz era boa. Aí separou o céu da terra, não foi assim? Depois criou as águas, os peixes, os animais até completar o trabalho todo. Depois Ele descansou. Até Deus descansou no sétimo dia. Mas a origem do homem mesmo é dia 25 de dezembro, não é? O dia do nascimento de Jesus, lá em Belém, Belém do Pará, não sei se você conhece. É perto do Rio Amazonas, aquele, que tem aquela história, que a mãe colocou o bebê numa cestinha, e colocou a cestinha no rio, pra quem encontrasse. Já imaginou? Um bebê daquele tamanho, navegando, sozinho, numa cestinha? Só Deus mesmo pra permitir uma coisa dessas. E depois é que veio a época dos castelos, dos reis, dos cavaleiros. Essa é a época mais maravilhosa da história da humanidade. Um verdadeiro conto de fadas. Tinha bruxa que morria queimada na fogueira; tinha cavaleiro com escudo, espada... São Jorge também acho que é dessa época. Pelo menos o jeitão do cavalo dele, assim, parece. Mas na época dele, de São Jorge, o ser humano ainda não tinha pisado na lua, não é? Isso foi bem depois. Tem gente que não acredita. É muita ignorância, não é? O pessoal anda dizendo por aí que tá acontecendo coisa, que o mundo vai acabar, que tá esquentando, que o sol tá ficando mais próximo da Terra, que vai explodir tudo... Mas, na minha opinião, isso é lenda. Hoje não tá bom? Não tá fresquinho?! Então. Não é dizer que o sol tá mais forte. Uma época é quente porque tem que ser quente. Eu acho que isso aí é fase. Daqui a pouco vem abril, aí é frio. Depois já vem agosto, é vento, aquele ventinho nojento, sabe? Depois, em setembro vem a primavera e outubro começa o calor. Eu acho que tem que acreditar nas coisas.

- Deus me deu o dom por causa que eu vejo as coisas que eles não veem. É uma visão que a pessoa não vê. Aqui ó. Tá vendo essa pedra que eu achei na rua, ali.? Tá vendo o estilo dessa pedra? Ela é toda quebradinha, assim, parecendo uma piramidezinha... Aí, co’a minha visão, eu falei assim: - Essa pedra tá aqui, no meio da rua, ninguém viu essa pedra, não!? No meio da rua! A pedra no meio da rua. Esse povo daqui não tem criação, não? Quê isso, sô! Aí eu trusse ela e coloquei aí. Essa pedra é criação de Deus - porque Deus é que cria as pedras também. E o Senhor falou: - Se o homem não falar no meu nome - igual se eu não reverenciasse o nome de Deus que tá por cima da nossa cabeça, porque Ele tá escutando aqui as minhas 
palavras, entendeu? e Ele falou: - Se o homem não falar, as pedras vão falar. Já imaginou!? Você passando perto de uma pedra e a pedra falando pra você: - Leia a Bíblia! Jesus tá voltando! Jesus reina! Heim!? Hã!? Aí nego ia até correr, né? Ver uma pedra falando!

- Eu morava na Extrema, trabalhava de vaqueiro... Mais ou menos umas 2 ou 3 horas da manhã, veio a luz andando, no pasto. Parecia uma luz de óleo. Andando.

- O povo fala, não sei, tem um tal de Juvenal, tatuzeiro, ele ia armar gaiola no meio do mato e pedia pra ela alumiá pra ele. E ela aparecia. Aparecia pra ele.

- Essa luz, quase todo mundo já viu ela. Ela não ofende ninguém, não. Ela sempre navega daquele morro, lá, até aquele outro pequenininho que tem ali. O giro dela é sempre esse. Ela sempre aparece.

- Existe ela que eu já vi. Essa luz. É uma luz grandona e branca, ela fica mudando de cor. Mãe do ouro, luz andeja... tem um monte de nome. Mas eu não fiquei com medo, não.

- Ah, faz medo. Não tem como. Porque é uma coisa que não é normal. Não é como um animal que você sabe que é animal. É uma coisa do outro mundo. Mas a onça é pior. A onça come. A onça pega. A onça mata. E a luz não. Agora a origem, isso aí ninguém sabe. De onde veio? O que é que pode ser? Será que ela transforma em outra coisa?

- Eu já vi ela. Ela é tipo uma bola, assim. Ela aumenta se você for encontrar com ela. Você vai, ela vem. Pra te encontrar. Quem já andou por esses lados aí - Vila de Fátima, Janela da Serra, Cavalinho - já viu essa luz.

- Ela fica do tamanho que ela acha que tem que ficar. Ela fica grande, ela diminui... Ela aparece pras pessoas, assim... Se você tiver medo, até que ela vai embora. Agora, se resistir contra ela, ela enfrenta a pessoa. 
- Lá em Vila de Fátima, tinha uma passagem duma serra, tipo uma cava dessa assim, ó, o dia que ela tava atentada, lá, ninguém passava.

- Meu tio. Ele tava voltando de uma festa meio doidão já. Aí o carro dele estragou. Quando ele foi abrir o capô, a chave dele caiu dentro do mata-burro. Aí ele pediu pra luz iluminar pra ele. E ela iluminou. É assim que ele conta.

- Esse Raimundo, irmão de Fátima, quase acabou com o carro, um dia, por conta dela. Ele tava lá na Fazenda da mãe dele, aí na hora de vir embora, o povo falou com ele: - "Ó, cuidado com a luz que ela pode te seguir! Aí ele: - "Ah, daonde? Essa luz não aparece pra ninguém, não! Isso é ilusão!” Ah! Aí quando ele vinha de lá aqui pro Morrão, ela montou em cima do rabo do carro dele, ela pousou no carro dele, e evém, e evém, immmm, immmm... No meio do mato. Nem ligar o carro ligava. Quase que ele morre. Só pra mostrar pra ele que ela existe. Porque ele abusou com ela.

- Eu já só vi falar nela. Eu mesmo nunca vi ela, não.

- Essa luz... Esse povo andando, aí, pras caçadas, sai, aí, em riba dum caminhão, pega, liga um lanternão, né? E aí, o povo pensa que é luz andando. Eu não acredito, não.

- Eu não acredito, não. Mas eu tenho que acreditar também. Porque um dia, eu passei bem medo também. Eu tava acabando de descer uma serra - só via fogo saindo dos cristal... - e tava um cavaleiro, ali. Aí eu pensei: eu vou correr de modo que eu vou pitar e beber um gole mais ele. Eu tava com um litro de pinga na sela e um cigarrão de palha pronto. Aí, eu apertei meu cavalo, meu cavalo saiu numa disparada, aí quando ia pra chegar perto, era só eu dar uma piscada, e o cavalo dele batia como daqui lá naquela cerca, quase. Uma vez, duas, aí eu pensei: vai matar meu cavalo correr atrás dele assim. Quando eu dei de virar pro outro lado, ele desceu direto. E eu só escutando a zoeira. Aí eu pensei: aquele baiano não quis falar nada comigo e nem me esperar foi por ruindade. Aí, eu sentei, bebi um gole primeira vez que eu bebi um gole na estrada - tô pitando, lá, e o meu cavalinho tá só andando em roda de mim... E eu segurando a corda, e ele andando em roda com 
a corda. Aí eu: - "O quê que é isso cavalo? Bobo! Você nunca viu o capeta, não!?" Aí o cavalo virou bicho deveras em volta de mim. E eu: uai, vai ver que esse trem aqui pode ser o capeta mesmo! Porque o cavalo tá desse tipo! Eu falei com ele e ele ficou com mais medo! Nisso aumentou a zoeira do estrado do pé do outro cavalo, o que foi diante de mim...Aumentou a zoeira... Poc, poc, poc... Uma altura! Só via a zoeira do cavaleiro na estrada. E o cavalinho meu também tava vendo. Mas eu falei com ele que ele arregalasse os olhos porque eu não conhecia o capeta, não. E o cavalinho meu foi ficando doido deveras. E eu: aquilo é o capeta, não é possível. Aí eu pensei, pensei... O que é que pode ser isso? Será que eu não tô muito com Deus? E o trem pra mim não tava bom mesmo não que o povo tava de má vontade demais comigo. Aí eu peguei o cavalo e fui embora. Cheguei em casa e fui dormir dentro do paiol. No outro dia, o cavalo amanheceu com os olhinho arregalado, a barriga vazia, fininho... Parece que dormiu amarrado num pau. Aí eu peguei ele, fui lá no córrego, banhei ele, pus um sal pra ele, olhei a mão dele - tava só um machucão, mas não tava ruim, não. - "Esse cavalo tá sofrendo." E eu:- "É medo, moço." - "O que que esse cavalo tem que tá fininho desse jeito?” - "É medo. O cavalo tá com medo, ele tá sofrendo." - "O que que foi?" - "Foi assombração. Ontem. E o trem não era mole, não. O trem era feio. Assustou demais mesmo.” Aí eu rezei uma oração mais forte, mais depressa, e pedi a Deus pra não deixar as coisas feias me pegar, não. Pra manter as coisa feia longe. Pra ir afastando as coisas feia também. Ah, isso, rezo. Rezo p'ra as almas, toda noite, e de menhã rezo pr'a mim...Pego com Deus. Aí desacismou o cavalo e desacismei eu também. Que eu também tava meio assombrado.

- Eu não tenho medo de capeta, não, que ele não existe.

- Pra mim existe. Existe e não existe. Depende da pessoa. Tem uma história de um homem que ficava fazendo gracinha com o nome do diabo, ali perto da praça, aí o capeta pegou ele de couro lá, num beco perto da casa dele.

- Uma vez, tinha um tal de Dete, doidozinho da cabeça. Aí esse cara ficava: - "Vixe! Vixe!" - "O que que é, Dete?" - "O capeta!" Eu falei: -"Dete, que capeta é esse, Dete?” - “Olha aí, ó! Olha aí, ó!” E eu 
falei: - "Eu não tô vendo nada, não. É você que tá com esse capeta." - "Nossa Senhora! Nossa Senhora!" "O que que é, Dete?” -“ Ó, o fogo! Ó, o fogo! A sua cabeça tá acabando de cortar o pescoço fora! Pi, pi, pi!" E quase levava a mão pra tirar o fogo que tava pegando em mim. Meu Deus do céu! Você nunca viu um doido daquele jeito! Só ficava falando em capeta, falando em fogo.

- Um dia desse, aqui, um sujeito veio de Curvelo, saiu lá do pronto-socorro, chegou aí, mandou o povo dele ir embora pra dormir sozinho. Aí quando o povo dele deu uma trégua ele não matou ele? Faca nele mesmo. Aquilo não tava com Deus, não. Aquilo tinha um capetinha junto com ele.

- Acho que, tipo assim: Deus fez as coisas boas e o capeta fez as coisas ruins.

- Mas parece que as pessoas boas, né?, Deus chama elas mais cedo. As pessoas boas Deus quer junto dele.

- É, é que nem trabalhador. Você é bom? Tá dentro. É ruim? Tá dispensado.

- Eu trabalho aqui no cemitério. Quando começa um, vai muitos. Depois pára. Época de frio é época que mais morre. Depois que morre, acabou. Cabou mesmo. Isso aí é fatal. Não tem nada, nada. Não tem como, não. Isso é história. Isso é de antigamente. Hoje não tem isso não.

- O cara que não paga e o cara que paga, depois que morre, é tudo igual?

- Quem faz tudo certo vai pro céu e quem faz tudo errado vai pra baixo. Falam que lá você apanha, lá pega fogo... Mas não adianta. Tem uns que faz errado assim mesmo.

- Uns vão pro inferno, outros vão pro céu. Tem muito bom que vai pro inferno. Igual muitos ruins vão pro céu. Os maus também tem que ter um lugar bom, não é? Lá no inferno agora tá cheio. Eles tão querendo soltar, agora.

- Se o cara foi direito, ele vai morar mais Deus. Então o cara vai estar bem. Já que Ele te chamou pra você 
morar mais Ele, já que Ele precisou de você pra te chamar... Tudo tem o dia do chamado, não é?

- Porque eu já sei. Já sei o que vai acontecer comigo. Não tem como eu tirar isso de mim. Porque eu sou artista. Sou poeta, cantor, compositor. E essa música minha, que tá aqui na minha cabeça, Ele me escolheu porque eu vou falar das flor, das madeira, das folha, do verde, do amarelo, do azul. Das mulheres, da memória, da cabeça, do coração, do rancho, do prédio. Das ruas, das estradas, do asfalto, da terra, dos passarim... De todas as coisas. Da natureza, das diferenças das frutas. Das diferenças das folhas das árvores, os modelos... Então, são muito diferentes as criação de Deus. As folhinhas, cada uma é de um modelo; um verde de uma cor, um verde de outra, o azul, as cores que ele criou. Eu vou falar de coisa que homem nenhum falou ainda. Das cascas da madeira, os desenhos dos paus, os frisos, entendeu? A música, a formiga, o cupim, o carrapato, essas coisas. Das pedras. Da humildade, da simplicidade, do respeito, da verdade, da sinceridade, dessas maravilhas. Do amor, da fidelidade, de tudo! Do anzol, do bambu, tudo! Eu vou falar de tudo que meu Pai criou.

- Essa é a cagaiteira. A folha seca pra fazer o chá é bom demais pro rim que ele é muito fresco. Tem a cervejinha, é uma raiz. É a cerveja mesmo. Você arranca a raiz dela, põe ela pra secar, aí bate ela, põe ela na água... Vai pondo assim, ela escuma igual a cerveja. Pro rim, você nunca viu bom desse jeito! É fresquinho e bom e até bom pra gente tomar. Tem o cajuzinho, é um pequenininho, ele dá sempre mais é na chapada, sabe? Pra diabete é bom demais. Tem o pacari, pra gastrite. Mas tem que tomar pouco. Põe ele, assim, numa vasilha de louça - porque se colocar ele numa vasilha que ele empretece, não pode tomar. Que ele é veneno. Ele é remédio e é veneno. Agora, pondo numa vasilha de louça, pode tomar. E, assim, não toma muito, não. É bom pra gastrite, bom pra qualquer inflamatório. Tem também o nharé, pro sangue. Esse é uma fruta, muito gostoso. Arranca a raiz dele e faz o chá. Pro sangue, pra pele, você nunca viu bom desse jeito. Tem o pau-do-touro, outros conhecem por jurema, o povo fala. Se a pessoa tiver com o intestino desregulado, aí pega ele, tira o entrecasco - tem que ser pouco - põe na água e toma. Num instantinho a pessoa tá boa, tá belezinha, tá sã. Se você tiver andando, no toco, tá 
com o intestino ruim? Pega assim um pedacinho da madeira, mastiga e loguinho você tá bom. Não precisa nem fazer o chá. Erva cidreira é muito bom também, pra febre, pra muita coisa. Tem o são-catchano. Ele gosta de dar na seca, assim, dá tipo dum cachinho com a frutinha._Você faz o chá da folha dele, toma ele, não tem febre que não corte. Pode estar queimando de febre, tomou, corta mesmo. Muito boa também é a hortelã-pimenta. Essa é a gente que planta ela, ela não é nativa da terra, assim, não. Pra nervo, bom é o alecrim. Põe o alecrim, abafa ele, toma o chá, que ele é bom demais pra nervo. Ele é calmante, o alecrim. Porque tem o maracujá também, muito bom pra acalmar o nervo. Se tomar muito até dorme demais. Tanto pode comer a fruta, como fazer o chá, o maracujá. Esse é um calmante muito bom também. Tem a trançagem, boa demais pra qualquer tipo de inflamação. Pode tomar um golinho ou pode banhar também. Ela é trançada mesmo. Tem o artemijo. O artemijo é bom demais, pra muita coisa. Se a pessoa até tiver meio passando mal, tipo de começar a dar um derrame, tomou o chá, ele recupera. O artemijo é bom demais da conta. Dá uma florzinha. O povo fala. Tem o kitoco também, que é muito bom. O povo até usa socar no tempero pra fazer comida. Vixe! Dá um sabor bom demais. Quituque. Tem a favaca também. É uma plantinha assim que dá um chá muito gostoso... Pra dor de dente, tem o nharé. Você tira o entrecasco dele e bate ele. Ô! Bochecha a boca, desincha e... Foi dor de dente! É bom demais. Nharé. Pra dor de cabeça tem um tal de capitão. É bom pra olhado ruim, dor de cabeça... Você vai na estrada, ele atravessou uma raiz, ali, você tira. Corta um pedacinho, tira 3 toletinhos, joga um fora, faz o chá de dois, e toma. Não tem dor de cabeça que não melhore. Pra bronquite, assim, aqui a gente usa muito mel de jataí. Sempre faz um chá de camará-do-reino, pega a flor dele, ou flor de mamão-de-corda, aí põe um melzinho de jataí... Você nunca viu bom desse tipo! Mas é bom mesmo. Esses são os remédios que nossa mãe fazia pra nós. Porque esses remédios, que a gente compra na farmácia, são todos feitos de planta. E quase toda árvore é remédio. Somente, às vezes, muitos não conhecem o nome. Igual assim: você tá viajando, dentro da mata, viu uma árvore que o passarinho bicou? Pode comer despreocupado porque, se o passarinho bicou, não é veneno. Antigamente, lá na roça, não existia remédio, quase, não, assim, de cidade. O remédio era ir lá no mato e pegar. Nós fomos criados desse tipo.

Pra tristeza? Ah, remédio pra tristeza é meio difícil. A gente tem é que tomar cuidado pra não deixar ela chegar. Porque eu acho que sempre a tristeza, se a pessoa 
tiver de mau-amor, aí é que traz a tristeza. Então se a pessoa procura sempre estar de bõamor, não tem tristeza. Comigo, graças a Deus, nunca existiu tristeza. Até hoje não. Teve assim, né?, tem hora que tem uma tristezazinha, assim, naquele momentinho ali... Mas passou, acabou. A tristeza já não me segue. Só ando alegre.

- Ah, pássaro tem muito, tem demais. Assaz quase milhares. Ichi! De pequenininho a grande, nesse pantanal aí, o que não falta é pássaro. Tem muita garça, tem aquele pato, aquele preto e branco, tem o paturi, tem o marreco, tem a saracura... Tem demais! Aqui tem muito é pássaro! Gavião tem muito. Carcará tem muito. Urubu... Esses passarozinhos pequenos tem demais. Tem joão-de-barro, maritaca, essa pomba verdadeira, tem juriti. Tem demais!

\author{
O engenho velho \\ deu de tremer \\ Põe cana nele \\ Deixa moer \\ Moeu, moeu \\ Virou bagaço \\ Moça bonita \\ Me dá um abraço
}

- Eu sou guaianeiro. A gente fala tirador de guaiana. Eu tenho diversos versos de guaiana. Muitos. A guaiana é o seguinte. Por exemplo, hoje a gente vai fazer a entrega do pé de milho. Aí chegava assim com as enxadas, juntava assim dez, doze camaradas, e logo começava a cantar. Nós cantamos até com cinco vozes. Começa de mim, que tira, que no caso seria o maestro, né? começa comigo e mais quatro. Aí nos cantamos com dois ternos. Um terno de cinco e outro terno de cinco. A gente canta, pára, o outro começa. A hora que eles param, a gente começa. Isso a gente faz capinando roça! Capina a roça e canta. Aí um cara fala assim: Ô, cumpadre, tira isso pra mim! E aquilo outro! E assim nós vamos. Eu aprendi com os mais velhos, com meu pai, meus avós. Isso vem de geração. Mas não todo mundo canta. Tem que ter o pequeno dom daquilo. Tem hora que eu invento assim umas estórias, eu 
falo uns versos assim, porque aí distrai o dia. Às vezes, a gente vai tomar um aperitivo, aí o povo fala: -“Fala um verso aí, cumpadre!” E eu:

Eu fui convidado
Pra festa no céu
Quem fez o convite
Foi seu Manoel
Achei no meu couro
Passagem e hotel
Pra livrar do sereno
levei meu chapéu
Cheguei lá no céu
achei muito engraçado
tava todo santo
num fogo danado
São Pedro queria
Matar São Geraldo
Por conta de um vidro
Que el' tinha quebrado
Dizendo que ele
É que era o culpado
Eu fui dar conselho
Pros dois não brigar
São Judas achou ruim
Quis arreminá
Meu sangue ferveu
Eu fiz o fuá
Acabei com a festa
Não pude dançar
Fiquei lá sozinho
Apanhei pra danar
a pinga eu que vou tomar

- Eu nasci na Sant'Anna do Ribeirão, onde tem uma capela, aí adiante. Fui criado na roça. Vivi na roça o tempo inteiro. Lá a gente sabe tudo o que acontece com o tempo. A gente já viu isso antes. Aquele bichinho que deu ontem, você lembra? O cupim? O tanto que deu? Bisorrinho. Sol puro. Pode esperar o sol. Não chove mesmo. A lua, quando tá marcando chuva, ela fica assim, ó, derramando. Quando ela é nova, ela não fica assim? Um risquim? Aí quando ela tá marcando chuva, ela fica assim, ó. Você pode olhar. Ela dá um circulozinho, ao redor dela: chuva longe. Quando dá o círculo longe, aí a chuva é perto. Se tiver pra chover, pode esperar que vai chover. O cupim reforma o cupim. Isso aí você pode esperar que vem chuva. $\mathrm{O}$ 
pau-terra não cai na poeira, e nem a cagaita. E os passarim também adivinha. Tem o rapa-rapa, igual tem aqui, que fica cró-cró-cró... Tem um passarim aqui, que se tiver chovendo e ele começar a cantar, um tal de peixe frito, não sei se você já escutou, de noite ele gosta de cantar: peeexx-fritu. Ah! É sol purim!

- Tudo significa, as coisas. A lima é pra comer a enxada; o serrote; o disco da maqueta; o arreio velho do cavalo; a foice... Isso aqui é um fogãozinho de lenha, significando, tá vendo? as coisinhas simples da terra... Essa vasilinha aqui é de fritar um ovo, chama frigideira, você já ouviu falar? Esse aqui, geralmente, eles usam aqui na roça co'o feijão, pra cozinhar o feijão, é o caldeirãozinho; essa botina é de sete léguas, de usar na roça, na água; essa telha é a melhor que tem, é o melhor telhado que tem, é a maior maravilha que Deus já criou no mundo. Esse tijolo aqui é o adobe. É de bosta de boi com areia, não é cimento, não. Faz a massa com a areia e bosta de boi, mistura e passa na parede com a colher. É desse jeito, o adobe. Adobe de barro, sem queimar. É pesado, do próprio barro, tem que pegar com as duas mãos pra colocar na parede. Faz primeiro era com a forma de tábua. Aí seca e coloca na parede já seco. Faz as paredes com ele e reboca com a massa feita com bosta de boi e areia. Esse pratinho aqui é esmaltado, de roça, caipira; a garrafinha de café... Esse canivete aqui é do cabo de osso, tá vendo? Esses osso aí que vocês tão vendo fabrica esse canivete aqui. Esse aqui é o bulezinho de café, significando...um jardim; essa aqui é a tampa da lata de leite, a boca da lata de leite, o selim da bicicleta... Essa aqui é a máquina de plantar arroz, ó, tá vendo? O arroz é plantado dentro dessa máquina. Essa aqui é a enxada pra limpar o arroz. Essa cabaça aqui significa garrafa de água dos trabalhador, que eles levava, antes, pra levar pro campo. Essa bolsa aqui significa quando eu saí daqui, ó, quando eu fui embora. O chinelim, mostrando também que eu era criança, quando eu saí. E essa_caixinha eu pus aí pra receber as correspondências... E aqui tem um violão, ó. Eu catei uns pedaços de tijolo, e falei: eu vou fazer um jardim, aqui. Eu cheguei aqui, quando eu cheguei aqui, eu mostrei procê aquela panela, uma piquinininha? Era aquela panela e o chão. Só. E o resto: uma bolsa. Aí, ó, o que você tá vendo aí, com dois anos que eu adquiri, eu adquiri catando essas coisas aí na rua. Fui catando esses negócio e pendurando aí. Fui catando, trazendo e colocando. Catando, trazendo e colocando. É assim que eu vou fazendo. E assim eu tô indo, e vai ser assim até o fim, até eu morrer! Porque eu sou 
artista, então Deus me deu essa inspiração de fazer essas coisas. A minha vida é a simplicidade e as coisas. E também sou construtor de usina. Você já ouviu falar em Oscar Niemeyer? A minha cabeça é igual a desses homens, de desenhar e localizar os projetos. Eu tenho essa visão... É dom de Deus, né? Uns acreditam em carro, outros em cavalo, nem todos vão ter fazenda e andar de carro novo, mas pra isso tem que pagar um preço. Já vi o mundo, já viajei de navio, enjeitei andar de avião mas agora eu não quero mais sair daqui não. Que se a gente for andar, a gente quer ir em muitos lugares. Não quero muita coisa, não. Quanto menos, melhor. Eu gosto é de pescar lambari ali embaixo, no córguinho. Vou lá, pego seis lambaris, venho aqui, faço um arroz e frito. Eu não tenho nada, não. Só tenho o dia e a noite. Só tenho o dia e a noite mas tá bom. Tem nada melhor que isso, não. Pra mim, não.

\author{
Vou me embora pra São Paulo \\ Meu dinheiro eu vou ganhar \\ Ajustei com a fazendeiro \\ Um grande homem do lugar, eh \\ Fazendeiro perguntou \\ Mas qual que é minha profissão \\ Sou carreiro e sou vaqueiro \\ E também sou um bom peão, eh
}

- E toda aquela viajada, uma coisa logo depois da outra, entupia, entricheirava; só no fim, quando se chega em casa, de volta, é que um pode livrar a ideia do emendado de passagens acontecidas. 


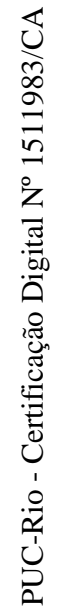

2 
CONSIDERAÇÕES CRÍTICAS

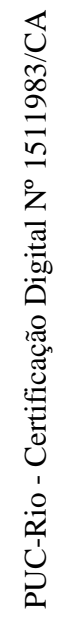




\section{O FILME}

Même si c'est vrai c'est faux.

Henri Michaux

20.12.2012.

1 Panasonic HVX200. 1 Canon 5D. 1 Canon mini HDV. Microfone de lapela. Boom. Gravador. Cartões de memória. Tripé. Computador. Cabos. Bateria. Carregador. Uma equipe recrutada entre amigos e familiares, e algumas - não muitas - ideias na cabeça: procurar reverberações do conto no lugar; embaralhar as fronteiras entre documentário e ficção; realizar um experimento de linguagem fílmica sobre a linguagem verbal.

O filme documental que integra este trabalho começou a ser produzido fora do âmbito da pós-graduação no curso da qual tomou sua forma atual. A versão que acompanha a dissertação é uma versão final, mas ainda não $a$ versão definitiva. As considerações aqui tecidas são uma tentativa de elaborar um pensamento sobre o trabalho realizado e dizem respeito, de um lado, às "forças formadoras" e de outro às "formas finais" do filme.

A obra de Guimarães Rosa possui um forte lastro documental a partir do qual as estórias ficcionais são construídas. A ideia inicial do documentário seres, coisas, lugares era fazer o percurso inverso, tomando como ponto de partida o conto "O Recado do Morro", e indo até o lugar em que se encontra o morro que aparece no nome da estória: o hoje município de Morro da Garça, no interior de Minas Gerais. A ideia era observar - e produzir - ressonâncias entre a ficção e a realidade, em diferentes planos: nos temas, na linguagem, nos personagens, nos objetos de interesse e, sobretudo, na atmosfera do filme. Não se tratava de tentar identificar a porção de realidade contida na ficção, no sentido de uma aferição de sua autenticidade, mas, ao contrário, de buscar, na realidade, seu quantum de ficção. $\mathrm{O}$ que interessava ao documentário não era o registro do cotidiano, a veracidade dos fatos ou o flagrante do real, e sim a capacidade de fabulação, o relato da experiência, as construções narrativas. O filme estava interessado naquilo que se expressa não 
através da linguagem, mas na linguagem, ou seja, não apenas aquilo de que a linguagem nos fala, mas a própria linguagem e também aquilo que, na linguagem, não se deixa falar completamente. Este entendimento, que está na base do filme, atravessa todo trabalho e configura-se como um de seus pressupostos fundamentais. A recusa do paradigma da linguagem como representação, implícita nesse pressuposto, impacta, obviamente, a escuta, a escrita e a leitura aqui realizadas, e repercute em todas as instâncias do trabalho. Essa atitude não ignora, todavia, que o modo padrão de funcionamento de nosso 'sistema operacional' é presidido por esse mesmo paradigma que queremos recusar.

O filme nasceu, portanto, de um desejo de escuta e da crença na afirmativa: "ser ouvido é ser legitimado". ${ }^{2}$ Com este objetivo - ouvir - a estratégia de abordagem do documentário estava definida: a entrevista. A ideia de um filmeentrevista, porém, previa, desde o início, a possibilidade de dar ao material filmado um outro uso que não o de mero documento da realidade.

Já em Morro da Garça, dispostos a abdicar da busca de uma certa verdade documental, optamos por trazer os entrevistados ao local da entrevista - a varanda da casa em que a equipe estava hospedada - em vez de ir ao encontro deles em suas casas. Esta escolha, motivada, em grande medida, por questões de ordem estética ter maior controle sobre a imagem, dotar o filme de unidade visual, manter o mesmo enquadramento em todas as entrevistas, não dispersar a atenção da fala com elementos cenográficos - acabou produzindo efeitos inesperados e benéficos e se revelando determinante para o filme: a varanda se transformou numa espécie de palco em que os entrevistados podiam performar, ficcionalizar, fabular à vontade (mais à vontade, provavelmente, do que se estivessem em suas próprias casas).

Sem perder de vista um conjunto de temas e questões sugeridas pelo conto , as entrevistas foram conduzidas como conversas espontâneas e, aparentemente, desinteressadas. $\mathrm{O}$ fato dos encontros serem em nosso território resultava ainda, de certa forma, numa acentuação, ou explicitação, da distância entre nós - os detrás das câmeras - e eles, os entrevistados, o que pareceu-nos uma boa forma de estabelecer a relação: não querer disfarçar a diferença indisfarçável.

\footnotetext{
${ }^{1}$ Neste trabalho, as aspas simples, exceto quando no interior de citações de terceiros, indicam expressões aproximativas ou intenção irônica. As aspas duplas indicam citações ou expressões criadas por outros autores.

${ }^{2}$ In: Coutinho, 7 de outubro de 2013. um filme de Carlos Nader
} 
Além das entrevistas, pretendíamos, num primeiro momento, gravar leituras de trechos do conto feitas pelos moradores. Posteriormente, na edição, tentaríamos criar um diálogo entre as leituras e as falas. A ideia era não suavizar a presença da literatura no cinema mas criar uma espécie de fricção entre as duas linguagens. Mas o descabimento dessa ideia não demorou a se revelar: os adultos entrevistados eram, em sua maioria, semianalfabetos, e a simples menção ao livro parecia deslocada. Com os jovens, a dificuldade foi inversa: letrados, eles conheciam o conto de corporque participam das encenações que acontecem na cidade - e a memória acabava interferindo negativamente na leitura.

O filme era movido, também, por um interesse etnográfico semelhante ao do próprio Rosa, ou ao do personagem seo Olquiste, o cientista alemão, com cuja perspectiva - a do estrangeiro, o que vem de fora, o letrado - podíamos, de certo modo, nos identificar. O herbário, as gravuras de aves, as listas manuscritas são momentos do filme contaminados por esse olhar. Da mesma forma, os planos fechados de pedras, troncos, areia são reveladores de um "olhar apalpado" - como querendo sentir a textura das coisas - presente tanto nas cadernetas de Rosa, como na atitude do personagem: "O louraça, seo Alquiste, parecia querer remedir cada palmo de lugar, ver apalpado as grutas, os sumidouros, as plantas do caatingal e do mato."3 A ideia de fazer um inventário poético de inspiração científica, expressa desde o título do filme, aponta para uma curiosidade indiscriminada e sem hierarquia que também se assemelha a do personagem e a do etnógrafo:

Foi Mauss quem melhor exemplificou essa atitude subjacente quando observou, como gostava de fazer: "A etnologia é como um oceano. Tudo o que você precisa é de uma rede, qualquer espécie de rede; e aí, se você entrar no mar e jogar sua rede, você pode estar certo de que vai pegar algum tipo de peixe." (CLIFFORD, 1998: p. 154)

O filme começa com o som. A tela preta e o som de passos sobre um terreno pedregoso. A primeira imagem é a de uma estrada de terra vista do ponto de vista

\footnotetext{
3 Todas as citações de "O recado do morro" referem-se à $9^{a}$. ed. da Nova Fronteira de "No Urubuquaquá, no Pinhém" (Corpo de Baile). A partir daqui, as referências ao conto serão feitas pela sigla RM seguida do número da página.
} 
de um caminhante, de quem ouvimos a respiração, através da qual podemos sentir o esforço da subida. Depois de um tempo, soam palavras esparsas:

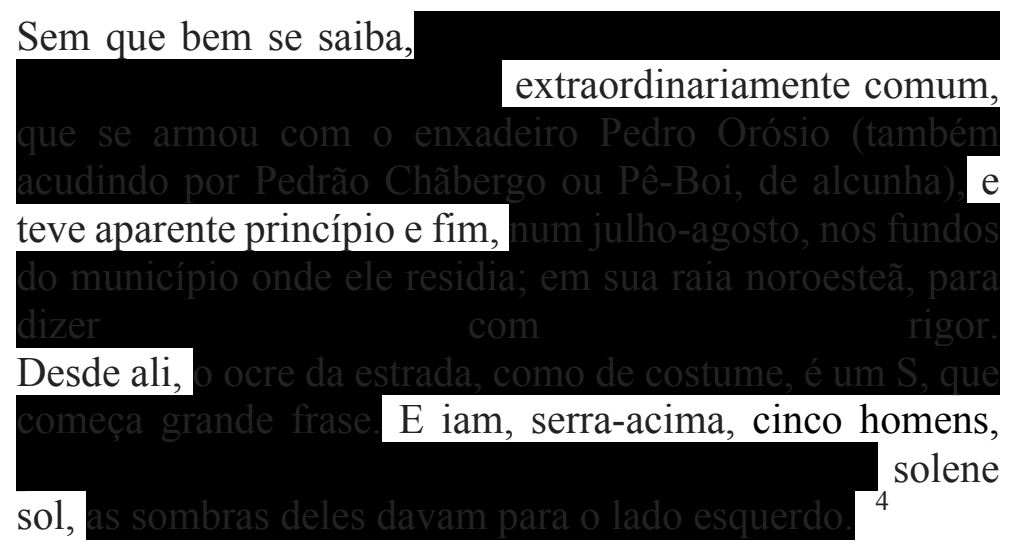

Essas palavras são fragmentos dos dois primeiros parágrafos do conto, mas a única informação de que o espectador dispõe, até ali, a esse respeito, é a que aparece como subtítulo nos créditos iniciais: "um diálogo com a obra "O recado do morro", de Guimarães Rosa". Sem que o espectador possa disso se dar conta, então, a imagem que vemos corresponde à situação descrita no texto - "Desde ali, o ocre da estrada como de costume é um $\mathrm{S}$ que começa grande frase (...) E iam, serra acima, cinco homens, pelo espigão divisor" - e poderia ser entendida como a visão subjetiva de um de seus personagens. Mas, no conto, dos cinco homens que viajam, apenas um vai a pé: o guia, Pedro Orósio. Logo, essa imagem equivaleria à visão subjetiva de Pedro Orósio, o protagonista da estória. A imagem nos coloca, pois, dentro da situação descrita no texto cujo sentido, no entanto, somos impedidos de alcançar. Estabelece-se, assim, desde o início, um tipo de relação com a palavra que não se limita à transmissão de um conteúdo.

Mas essa imagem, ambígua, também pode ser vista como aquilo que, na verdade, é: a visão subjetiva do fotógrafo, na qual estaria incorporada a visão subjetiva do autor (aquele a quem pertencem as "notas avulsas de uma viagem ao sertão"), cuja presença o filme não tentará disfarçar.

Desse modo, o filme constrói seu olhar, e o do espectador, entre imagens objetivas - o que a câmera vê - e imagens subjetivas de diferentes extrações - o que 
o personagem do documentário vê, o que o autor-personagem do filme vê, e ainda o que o personagem do conto vê - sem nunca deixar muito claro quem vê aquilo que vemos.

Ao não se preocupar em identificar, nitidamente, quem vê aquilo que vemos, a narrativa se instala numa zona de indeterminação que talvez aproxime o filme daquilo que Gilles Deleuze chamou “documentário falsificante”. Segundo Deleuze, um mesmo regime de verdade preside a construção tanto dos filmes documentais quanto dos filmes de ficção. Esse regime consistiria, basicamente, na sustentação dessa distinção entre imagens subjetivas e imagens objetivas.

Nessa mesma sequência inicial, o procedimento relativo ao áudio (que se repete em momentos posteriores do filme) consiste em 'esburacar' o texto, de modo que o sentido não se complete. O que se exibe, portanto, é o poder de sugestão das palavras e não um enunciado inteligível. Livre da função de comunicação, é a dimensão sonora - timbre, ritmo, duração - que sobressai. Aqui, gostaríamos de chamar a atenção para um detalhe a respeito do modo como esse procedimento foi realizado. Em vez de gravar apenas os fragmentos escolhidos para soar, decidiu-se, numa autoimposição, usar a leitura integral do parágrafo como base e emudecer os trechos indesejados. Assim, retirando as palavras do fluxo da leitura, tanto a inflexão quanto um certo ritmo da frase são preservados, e é como se conservássemos uma camada subterrânea de som, inaudível mas, de alguma forma, presente.

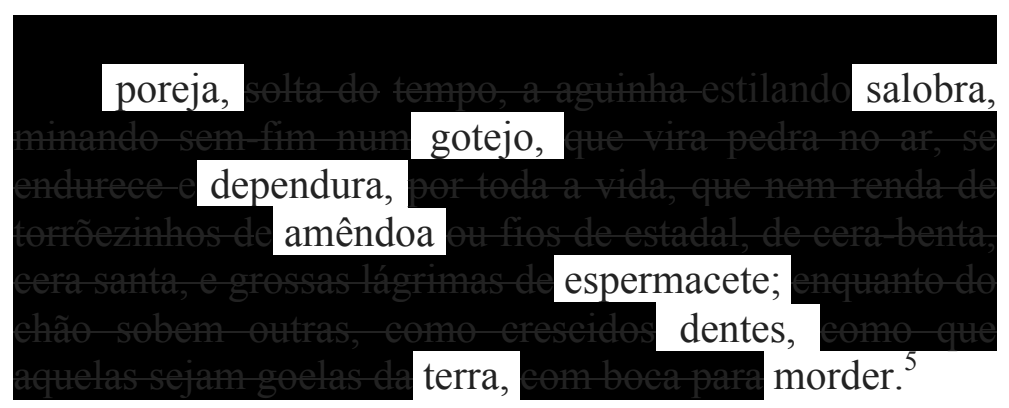

Pouco depois dos créditos iniciais, 'chegamos' ao morro da Garça, o acidente geográfico. Mas, antes de ver o morro, ele mesmo, o que vemos é uma 
série de figurações da montanha, que aparecem dupla e, às vezes, triplamente enquadradas: o morro pintado num muro de rua, numa parede, numa tela, numa foto emoldurada, o morro através de uma janela. Esse jogo de imagens, uma espécie de mise-en-abîme, aponta, de certo modo, para a ideia de que tudo o que se vai ver é mediado, nunca 'de primeira mão'. É como se, ciente da inacessibilidade da coisa em si, o filme afirmasse, desde o início, a mediação como sendo aquilo que realmente interessa. Ou, ainda, como se o documentário apresentasse a si mesmo como (mais) uma forma de mediação.

Mais adiante, o personagem Washington, tomando da parede uma moldura de madeira vazia, enquadra, através da janela, o barraco de barro onde ele foi gerado. De novo, aqui, um triplo enquadramento: a moldura, a janela, o fotograma. Eu quero colocar a foto desse barraco num quadro, tá vendo? Eu quero colocar aquela parede aqui dentro, tá vendo?

Se as entrevistas são a base do filme, o uso que se faz das falas varia tanto do ponto de vista material - in, off, escrita - quanto do ponto de vista da narrativa. Por exemplo: aos 40', aproximadamente, vemos a imagem de uma lua cheia - uma imagem de baixa resolução, caseira, granulada, desfocada, tremida - enquanto ouvimos uma estória de assombração contada - como tendo sido vivida - por um dos entrevistados:

Lá era mal-assombrado. De noite, quando a gente ia deitar, na hora que a gente deitava na cama, que apagava a lamparina - que não existia energia, né? - essa assombração virava um trem fora de série dentro dessa casa. Pegava armário, tombava lá no cimento, assim, quebrava as vasilha tudo. Esse trem ia lá no nosso quarto, pegava a coberta na barra da cama e torcia ela, assim, $e$ ficava dando baque. E eu mais ele deitado com as cobertas, a gente sentia aquela assombração puxando e fazendo isso com a coberta. Ai a gente acendia a lamparina e era só enquanto riscava o fósforo parava tudo, ninguém via nada.

Nessa sequência, a estória contada é presentificada no plano sonoro - com ruídos de passos e portas rangendo - enquanto a imagem - a fachada de um casebre mal iluminado - sugere o cenário da ação. No terço final do filme, esse deslizamento - entre narração e encenação, documental e ficcional, fantasia e 
realidade - acentua-se progressivamente. Quem vê aquilo que vemos? Quem diz aquilo que ouvimos? Em off, ouvimos as badaladas de um sino, em meio a muitos ruídos, e um trecho 'esburacado' do conto, que fala em fim de mundo, seguido de falas colhidas nas entrevistas sobre o mesmo assunto:

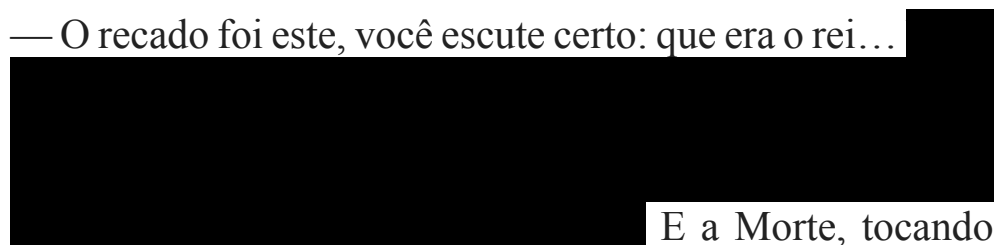
caixa, naquela festa. A Morte com a caveira, de noite, na festa. E matou à traição.

Todos tremeram em si, viam o poder da caveira: era o fim do mundo. ${ }^{6}$

- Ô Tonico, o mundo vai acabar! Nós vamos morrer de fome, de sede, assado, cozido, torrado no sol!

- Acabou em água, uma vez, agora vai acabar em fogo.

- O mundo acaba é pra aquele que morreu. De vez em quando vai um. Depois vai um punhado. Uns morrem de trombada, outros morrem caído n'água, outros morrem de queda de avião...

- Eu nunca lembrei que o mundo acaba, não. Tem escrito no catecismo: o mundo não teve princípio e nem terá fim. O mundo velho é muuuuitcho mundo!

Na última sequência, vemos as imagens dos 'reis' da Folia de Reis - com suas roupas de cetim, suas "espadas" feitas de cabo de vassoura, suas máscaras e coroas - servindo de matéria para a construção de uma cena de teor ficcional. $\mathrm{O}$ filme termina e, no momento dos créditos finais, as imagens da Folia de Reis retornam, agora acompanhadas do áudio original, e retomam o lugar de imagem documental.

seres, coisas, lugares é um filme híbrido e heterogêneo não só do ponto de vista da mise-en-scène como também do ponto de vista material. A sequência descrita acima começa com um plano desfocado, borrado, filmado acidentalmente. Não é a primeira vez que a montagem incorpora imagens que, normalmente, seriam 
desprezadas. São erros, defeitos, acidentes, restos, ou, às vezes, simplesmente, “imagens ruins", de baixa resolução, com problemas na captação. Mas também isto, aqui, significa e, a esse respeito, gostaríamos de fazer algumas considerações.

Nos créditos finais de Adeus à linguagem, de Godard, aparecem elencados, em igualdade de condições (fonte, tamanho, posição na tela), os atores, os autores, as obras, os técnicos e os modelos de câmera usados na filmagem. É que, mesmo que o espectador não tenha consciência, a qualidade material da imagem - que pode, de certo modo, ser aferida em termos técnicos - também é portadora de significado. Essa qualidade - ou a ausência dela - pode ser traduzida em valor financeiro e este dado, mesmo quando não é percebido com clareza, produz um efeito, um impacto na recepção.

Durante o processo de montagem de seres, coisas, lugares, as imagens capturadas com uma terceira câmera - pequena, doméstica, obsoleta - foram as últimas a serem incorporadas ao material bruto, num estágio já avançado da edição. Ao serem inseridas no filme, essas imagens, visivelmente precárias, evidenciavam o caráter modesto da produção e isto, ao invés de negativo, foi considerado favorável àquilo que desejávamos do documentário.

Além de imagens em movimento, o filme se serve de fotos, gravuras, desenhos, manuscritos e cartelas de texto. Esses materiais foram escolhidos e inseridos durante a edição, cada um por um motivo específico, mas a possibilidade de recorrer a elementos exteriores à filmagem, buscados em outras fontes esteve sempre presente: o filme seria construído, em grande medida, na ilha de edição. Assim como uma espécie de 'falta de pudor' quanto à procedência dos elementos a serem inseridos, que tanto poderiam ter origem 'nobre', como as páginas das cadernetas de Rosa, como poderiam ser artesanalmente produzidos para a ocasião, como o caderno de naturalista amador. As gravuras de J.Th.Decourtilz, francês que percorreu o interior do Brasil durante o século XVIII, vieram preencher uma lacuna em nosso acervo de imagens garantindo a imprescindível presença das aves e, além disso, trouxeram para o documentário, mais uma vez, de outra maneira, a figura do viajante naturalista. ("Tudo deve ser cacho de acordes. Como no xadrez: a jogada boa deve ter mais de uma finalidade ou causa".) ${ }^{7}$ 
Assim como acontece com relação à imagem, também a materialidade da palavra expressa, em si mesma, alguma coisa. A letra manuscrita utilizada no filme - incluindo sua caligrafia - traz uma 'informação' que não está presente na letra eletrônica. Muitos desses inserts - os mapas, os manuscritos, o herbário - são usados para conferir ao filme a desejada dimensão de caderneta de viagem. O que se exibe através deles, porém, é a própria artificialidade da construção do documentário. 


\section{O MESMO, O OUTRO}

Ele era-um meu personagem:

Eu era personagem dele!

J.G.Rosa

Onde agora? Quando agora? Quem agora?

Beckett

Os meses e os dias são viajantes da eternidade.

Bashô

As relações entre literatura e etnografia se dão por muitas vias e são muito anteriores à própria constituição da disciplina enquanto tal. As origens da etnografia remetem aos relatos dos viajantes naturalistas que, sobretudo no século XIX, saíram da Europa para conhecer e descrever lugares distantes. Esses relatos, que podem ser lidos como obras literárias, acabaram colaborando significativamente não só para o reconhecimento dos territórios percorridos como para a construção de uma imagem - uma autoimagem - dessas nações, entre elas, o Brasil.

Guimarães Rosa foi um leitor de viajantes e um viajante ele mesmo, um dos expoentes, segundo Silviano Santiago, de uma "vertente antropológica" da ficção brasileira da qual Euclides da Cunha e Mario de Andrade também fariam parte: escritores que deixaram seus gabinetes e saíram em busca de "literatura em matéria”. Entre os anos 40 e 50, o escritor percorreu o sertão de Minas, da Bahia e o Pantanal mato-grossense munido de cadernetas onde ia registrando o que via e ouvia durante a viagem: os nomes das plantas e dos bichos, as cores e as formas, os cheiros e o sons, as cantigas, os ditados, os provérbios e as estórias. "Como já vinha estudando, nos livros e nos museus europeus, a tradição épica culta, lançou-se à pesquisa sistemática da mesma tradição na linhagem popular sertaneja."8 Essas 
anotações - que encontram-se sob a guarda do Instituto de Estudos Brasileiros (IEB) da USP e foram, recentemente, parcialmente publicadas sob o título A Boiada serviram de base para as monumentais obras lançadas em 1956: Grande sertão: veredas e Corpo de baile, livro no qual encontra-se "O recado do morro".

Em "O recado do morro", o motivo da viagem, marcadamente presente em toda a obra de Rosa, manifesta-se em diferentes planos. No plano do enredo, o conto narra uma viagem de ida e volta entre Cordisburgo, cidade natal de Guimarães Rosa, e a região conhecida como Gerais, que fica além do Rio São Francisco, na vertente do Rio Formoso. A comitiva - “cujo desígnio parece incompreensível, cuja viagem não parece ter outra finalidade senão a de demorar-se em seu próprio desdobramento, no esmiuçamento da paisagem"9 - é formada por um naturalista estrangeiro, seu Olquiste ou Alquiste, "sempre nas manias de remexer e ver, perguntar, e tomar o mundo por desenho e escrito" ; um padre, Frei Sinfrão, "sempre rezando, em hora de folga, com o terço ou no missalzinho"; e um fazendeiro, Seo Jujuca do Açude, "rapaz moço e daqui, mas com seus estudos da lida certa de todo plantio de cultura, e das doenças e remédios para o gado, para os animais." A pé, na frente, guiando o grupo de viajantes, vai o enxadeiro Pedro Orósio, "também conhecido como Pedrão Chãbergo ou Pê-Boi, de alcunha"; e atrás, tangendo os burros cargueiros, o tropeiro Ivo Crônico.

Em paralelo a essa viagem, um recado, que teria sido emitido pelo próprio Morro da Garça, viaja de boca em boca, através de sete recadeiros, até se tornar uma canção, na voz de um cantor popular, quando, então, seu sentido se revela: trata-se de uma sinistra conspiração envolvendo morte e traição. Assim, numa "combinação indecidível de acaso e teleologia", 10 a mensagem que irrompe da terra vai sendo progressivamente deformada até chegar a sua forma definitiva. "É como se a linguagem não se tornasse ela própria, não se convertesse em si mesma, a não ser na medida em que aproxima de seu limite e de seu contrário."11

\footnotetext{
9 PRADO JR. 1985: 213

10 WISNIK, José Miguel.

11 PRADO JR., Bento.
} 
Mas a viagem da comitiva, no conto, reproduz ainda, de certo modo, as viagens do próprio Rosa por aquela região, e o personagem seu Olquiste, que "tomava nota, escrevia na caderneta; a caso, tirava retratos", pode ser visto tanto como um alter ego do escritor, quanto como uma personificação daqueles viajantes naturalistas, cujos relatos Rosa gostava de ler.

Por fim, a viagem é também uma espécie de método deste trabalho que, à semelhança de Rosa, desenvolve sua tarefa com base numa pesquisa de caráter etnográfico.

Em todas essas viagens - a de Rosa, a de seus personagens, a do filme podemos vislumbrar um mesmo desejo de 'outro', daquilo que, na modernidade, se chamou, em oposição à identidade, alteridade. Mas o que a busca do "outro" revela, ao final, é que ela é quase sempre uma busca do 'eu'. "O que toda experiência de uma outra cultura nos oferece é a ocasião para se fazer uma experiência sobre nossa própria cultura."12 Nesse sentido, a formulação de Philippe-Alain Michaud a propósito da viagem ao México empreendida pelo historiador da arte alemão Aby Warburg pode ser iluminadora:

\begin{abstract}
Warburg havia compreendido, em 1923, que a experiência da alteridade é necessária para interpretar o familiar, que a distância geográfica é uma metáfora do passado - tão íntima e pessoal quanto histórica e coletiva - e que a viagem é uma técnica de anamnese. O tema exótico, que permite ao historiador compreender e controlar as operações que ele executa, deixou de ser um simples objeto de pesquisa para se tornar seu reflexo, abrindo o saber para a consciência da alteridade. (MICHAUD, 2013:38)
\end{abstract}

A ideia da distância geográfica como metáfora do passado pode ser questionada - como faz Hal Foster, no texto "O artista como etnógrafo" presente no livro $O$ retorno do real - na medida em que faria supor um entendimento da história como um processo sequencial evolutivo. Embora rejeitando este entendimento, devemos dizer que, na experiência deste trabalho, o deslocamento 
no espaço provocou, muitas vezes, a sensação de um deslocamento no tempo tornando clara a percepção da convivência entre tempos distintos.

A comitiva que viaja, no conto, - "pessoas instruídas, gente de mando" - é formada por um cientista estrangeiro, um fazendeiro e um sacerdote, "um cortejo emblemático da elite colonial brasileira", como assinalou José Miguel Wisnik. A cavalo vão os homens letrados, guiados e seguidos por um trabalhador rural e um tropeiro. A viagem é, portanto, palco para a convivência entre diferentes modos de saber - o saber racional, letrado, científico, de um lado; e o saber popular, intuitivo e prático, de outro - numa espécie de embate que atravessa toda a narrativa:

Compondo a novela, lê-se, em tom cômico-sério, uma espécie de disputa entre os saberes: de um lado, o cientista alemão admira os elementos mais corriqueiros da paisagem, para espanto e galhofa dos camaradas geralistas; de outro lado, moradores bobos ou meio malucos sustentam profecias, creditadas à voz do morro, que são desconsideradas pelo padre e pelo fazendeiro. (CARDOSO, 2003: 149)

Esse trânsito entre diferentes perspectivas de conhecimento que tem lugar na ficcão, se reproduz, em muitos níveis, na experiência deste trabalho que é, em seu conjunto, produto do encontro entre um 'eu' letrado e um 'outro' semiletrado. Aqui, podemos pensar, com Bento Prado Jr., que esse par - letrado/iletrado - cuja presença é frequente na obra de Rosa, recorda, de alguma forma, a relação da espécie humana consigo mesma, antes e depois da escrita.

Mas como falar em 'eu' sem desconfiança? Como falar em 'eu' sem colocar o próprio 'eu' em causa? De que 'eu' afinal estamos falando? Não de um 'eu' estável, unificado, como princípio de identidade fixa, reduzido a um núcleo essencial, como na concepção clássica de sujeito, mas de um 'eu' que nunca é igual a si mesmo, um 'eu' que se transforma permanentemente e se constrói em contato com o 'outro'.

'Eu' e 'outro' são entendidos, aqui, portanto, como posições provisórias, comutáveis, móveis. Pontos de vista de referência, perspectivas, 'lugares'. E cada 
'eu' e cada 'outro' é habitado e se transforma em 'outros', permanentemente. Numa espécie de parentesco analógico, então, dizer 'eu' seria como, nas palavras de Borges, dizer 'tigre':

Considerei que mesmo nas linguagens humanas não existe proposição que não implique o universo inteiro, dizer o tigre é dizer os tigres que o geraram, os cervos e tartarugas que ele devorou, o pasto de que se alimentaram os cervos, a terra que foi mãe do pasto, o céu que deu luz à terra. (BORGES, 1999: 663)

Em “O recado do morro”, o ‘outro', primeiro, é um ‘outro’ mais radical o morro - não o 'outro' do 'eu' psicológico, individual, mas um 'outro' “exterior e anterior à própria humanidade, domínio onde ainda não se dissociaram logos e fisis". "13. Mas são muitos os 'eus' e muitos os 'outros' postos em ação no conto. Enquanto seo Olquiste é o outro-estrangeiro, o outro-letrado, o outro-cientista, Pedro Orósio, “oriundo de outro espaço, inconfundível com aqueles com quem, acidentalmente, partilha sua situação", ${ }^{14}$ também aparece, desde o inicio, como “outro”. O próprio Rosa é, sabidamente - e sagazmente - um 'eu’ habitado por dezenas de 'outros'.

Cada um desses, como representante de um tipo de estória ou cantiga, tem sua figura fundida à imagem do escritor, que, assim, assume diferentes faces, simultâneas ou sucessivas - a erudita, de "ledor de Homero"; a nacional, de discípulo de Euclides da Cunha; a boiadeira, andarilha, imitada do admirável guieiro Zito; e a de observador de seres excepcionais, espertamente captada num descuido do fazendeiro-empresário Barbosa. (CARDOSO, p.152)

Na relação entre 'eus' e 'outros', o interesse pelo diferente, pelo não-familiar, pode ser avistado também no comportamento dos personagens: enquanto Pedro Orósio, o nativo, "gostava era de se casar com uma assim de cara rosada, cabelo

\footnotetext{
${ }^{13}$ PRADO JR. 1985: 212

14 PRADO JR., 1985: 214
} 
amarelo e olho azul...", seu Alquiste, o estrangeiro, se pudesse, gostaria de se "casar com uma mulata daqui, uma dessas quase pretas de tão rôxas..."15

Em “O artista como etnógrafo", já referido anteriormente, Hal Foster sugere que existiria uma "virada etnográfica" na arte e na teoria, a partir dos anos 70. Embora pudéssemos ser tentados a ver o presente trabalho como um produto tardio e longínquo dessa virada, é na ideia de um "surrealismo etnográfico", assim como foi pensada por James Clifford, que acreditamos poder encontrar certas afinidades com o modo etnográfico como nos aproximamos do sertão. Entre essas afinidades estariam, por exemplo, o abandono da distinção entre "alta" e "baixa" cultura, que a etnografia compartilha com o surrealismo, além da valorização de "fragmentos, coleções curiosas, inesperadas justaposições”, característica da estética surrealista. Citando Clifford: "Ver a cultura e suas normas - beleza, verdade, realidade - como arranjos artificiais suscetíveis a uma análise distanciada e a uma comparação com outros arranjos possíveis é crucial para uma atitude etnográfica."16

Se, no inicio do século $\mathrm{XX}$, as sociedades ditas primitivas estavam cada vez mais disponíveis como fontes estéticas, cosmológicas e científicas, atualmente, com o processo de globalização - expressão que oculta o fato de que se trata de uma ocidentalização do mundo - o "outro" tem se tornado - num certo sentido, apenas cada vez mais raro. A contaminação de que se queixou Lévi-Strauss, em Tristes Trópicos, ocorre agora em escala global. Diferente disso, porém, o que parece se revelar, nesta pesquisa, é a presença, a sobrevivência e a potência de uma "outridade" nem tão distante e bastante radical.

${ }^{15}$ RM: 33 


\title{
3. DOIDOS E NAO-DOIDOS
}

\author{
si un aveugle me demandait \\ as-tu deux mains \\ ce n'est pas en regardant \\ que je m'en assurerais \\ oui \\ je ne sais pas \\ pourquoi \\ j'irais faire confiance \\ à mes yeux \\ si j'en étais à douter \\ oui, pourquoi \\ ne serait-ce pas mes yeux \\ que j’irais vérifier \\ en regardant \\ si je vois \\ mes deux mains \\ J.L.Godard
}

A obra de Guimarães Rosa é povoada de personagens excêntricos: doidos, bobos, alucinados, além de crianças, velhos e artistas, ou seja, todos aqueles em quem a racionalidade encontra-se, provisória ou definitivamente, debilitada. Em " $\mathrm{O}$ recado do morro" vemos desfilar uma série deles: o Gorgulho, que mora sozinho numa gruta e é quem ouve o morro falar; O Catraz, que planeja se casar com a "moça da folhinha"; o Nominedômine, um 'profeta' que anuncia o fim do mundo; o Guégue, um bobo que toma burros e galinhas como pontos de referência; e ainda o Coletor, que passa os dias calculando o tamanho da fortuna que imagina possuir.

São seres excepcionais, dotados de uma percepção aguçada, que ouvem e distinguem coisas incompreensíveis para os demais - como a voz da natureza, de Deus e seus profetas. Vivem na encruzilhada entre o que é definido como o humano e o natural, e concebem o mundo segundo uma lógica diversa do senso comum, e por isso mesmo desqualificada como impossível ou inverossímil. Falam línguas estranhas, de conteúdos enigmáticos, frequentemente atribuindo outros nomes para as coisas e novos significados para os nomes, ou simplesmente criando 
nomes motivados por inusitadas sinestesias. (MARTINS

COSTA, 2005:50)

A simpatia que o autor devota a esses seres excepcionais serve, entre outras coisas, ao questionamento da lógica racionalista, um dos traços mais significativos da obra rosiana. Mas, diferente do que acontece no realismo fantástico de outros grandes autores latino-americanos do mesmo período, em Rosa, a perspectiva racionalista, embora permanentemente interrogada, nunca é abandonada por completo:

Guimarães Rosa está consciente de que o sertanejo é um ser dividido entre dois universos distintos, de ordem míticosacral e lógico-racional, e o que faz é pôr em xeque a tirania do racionalismo, condenar sua supremacia sobre os demais níveis de realidade. Rosa não rejeita o racionalismo como uma entre outras possibilidades de apreensão da realidade, mas procede a uma avaliação e relativização de sua autoridade, do cunho hegemônico e dogmático que este adquiriu na tradição ocidental. Neste sentido questiona a todo instante o realismo tradicional em suas obras e insinua freqüentemente a viabilidade do mito, mas tampouco se encerra na perspectiva deste último. (COUTINHO,1995: 20)

A presença desses seres excepcionais, assim como a dos animais, é também uma forma de forçar os limites da palavra, de "estrangeirizar" a língua, tirando-a dos sulcos em que ela, habitualmente, se move e fazendo da escrita o lugar de uma experiência radical. Além disso, ao dar voz àqueles que normalmente não falam, ou não são ouvidos, Rosa efetua "verdadeira desconstrução do discurso hegemônico da lógica ocidental." ${ }^{\prime 17}$

Entre os moradores entrevistados para o filme - uma amostra completamente aleatória e sem nenhum compromisso de representatividade encontra-se também um desses seres excepcionais, Washington, que à semelhança do personagem Nominedômine, declara: Porque eu sou profeta, o ungido, o escolhido de Deus. Tá vendo a minha voz? A presença de Washington, tanto no 
filme como no 'texto', adquire lugar especial não só pela singularidade de sua personalidade - e de seu discurso - como também pelas condições e duração da entrevista. Ao contrário dos outros entrevistados, a conversa com Washington aconteceu na casa em que ele vive, um casebre paupérrimo, sem luz e sem água, sobre o qual ele diz: Aqui pra mim é melhor do que qualquer lugar do mundo. Aqui pra mim é a mesma coisa que estar numa mansão!

No discurso de Washington, como no do personagem do conto, tudo vem vazado em uma linguagem mítica e apocalíptica de alta potência poética. Diferente do sujeito que se supõe no controle da língua, Washington parece ser arrastado pelo fluxo da própria linguagem entregando-se sem resistência à torrente da fala. Convencido de que não é ele que fala o que ele fala, de que é Deus que fala através dele; nem completamente submetido, nem completamente alheio à lógica racional, Washington nos oferece uma completa e complexa cosmovisão cuja dimensão mística transcende a religião específica de onde provém. As palavras de Georges Bataille, em texto sobre o poeta William Blake, ajudam-nos a pensar:

Essa identidade entre o homem e a poesia não tem apenas o poder de opor a moral e a religião, e de fazer da religião a obra do homem (e não de Deus, não da transcendência da razão), ela devolve à poesia o mundo em que nos movemos. Esse mundo, de fato, não é redutivel às coisas, que nos são ao mesmo tempo estranhas e subordinadas. Esse mundo não é o mundo profano, prosaico e sem sedução, do trabalho (...): só a poesia, que nega e destrói o limite das coisas, tem a virtude de nos devolver à ausência de limite; o mundo, numa palavra, nos é dado quando a imagem que temos dele é sagrada, pois tudo o que é sagrado é poético, tudo o que é poético é sagrado. (BATAILLE, 2015: p.80)

Como um profeta bíblico, Washington foi enviado por Deus para fazer o bem, trazer a paz, a fartura, e sofre a incompreensão dos demais. Mas como um poeta, ele é capaz de enxergar o 'milagre' que se esconde num fato corriqueiro, de ver o sagrado no banal: Você tá vendo essa terra vermelha, aqui? Tudo o que você que planta dá! Se você jogar uma semente de feijão, ela nasce! Sem você fazer nada, sem cultivar. Só Deus é que faz ela germinar. E aquilo que poderia ser apenas uma platitude adquire, na sua fala, um tom de revelação: Não é a gente que escolhe. É Deus que escolhe pra nós. Se a gente escolhesse, todo mundo era rico! 
Ao tornar possível a questão crucial (o que é o que é?), o analfabetismo nos devolve a uma perplexidade diante do destino de que nos afastara a falsa sabedoria sedimentada nos dicionários. Perplexidade que nos apresenta o destino não como problema susceptível de uma resolução intelectual, nem como mistério, que transcende irremediavelmente os recursos do entendimento, mas como enigma, como um texto obscuro e hermético a ser decifrado. (PRADO JR, 1985: 200)

Ao longo da entrevista, Washington anuncia, insistentemente, sua condição de artista: Porque eu sou artista. Sou poeta, cantor, compositor. Não tem como eu tirar isso de mim. A certa altura do filme, ele aparece empunhando um microfone sem fio com o qual apresenta um número musical. O microfone, que ele fez questão de buscar, embora não funcione, é elemento imprescindível à sua performance, como se, assim como o 'hábito faz o monge', o microfone fizesse o cantor. Num jogo de faz de conta, o gesto de Washington instaura, nesse momento do documentário, um estado de ficção.

A música que ele canta, "Menino do Sinaleiro", da dupla sertaneja gospel Daniel e Samuel, vem nos lembrar que, no caldo cultural no qual Washington encontra-se imerso, as memórias ancestrais convivem, lado a lado, com elementos da cultura de massa. Na Festa da Lavoura, que acontece anualmente na cidade, há mais de cinquenta anos, os shows de pagode, sertanejo e funk, por exemplo, dividem lugar com as procissões religiosas e outras manifestações tradicionais, como a "guaiana" - música que celebra a colheita - e a Folia de Reis.

Para Washington, artista é aquele que tem o dom e este dom consiste em ver aquilo que os outros não veem, ser capaz de enxergar (a beleza das coisas jogadas fora, por exemplo). Deus me deu o dom por causa que eu vejo as coisas que eles não veem. É uma visão que a pessoa não vê. Artista, então, é aquele que vê. Criar é ver. E ver, assim como ouvir, é reconhecer, legitimar, dar valor. Ele tem o dom da visão e o dom da voz. Mas, num caso como no outro, não é ele que vê o que ele vê, não é ele que fala o que ele fala. É Deus que mostra, é Deus que fala. No seu entendimento, então, o artista seria um lugar de passagem, o meio através do qual algo, que não ele próprio, fala. 
Entre o discurso de Washington, 'o doido', e os outros moradores, 'nãodoidos', a diferença não está no grau de plausibilidade daquilo que é dito. Se o primeiro garante ouvir a voz de Deus, os outros se comunicam com uma misteriosa luz que costuma aparecer por lá: O povo fala, não sei, tem um tal de Juvenal, tatuzeiro, ele ia armar gaiola no meio do mato e pedia pra ela alumiá pra ele. E ela aparecia. Aparecia pra ele.

"Doidos" e "não-doidos" concebem o mundo segundo uma lógica diversa daquela do racionalismo cartesiano predominante em nossos modos de vida ocidentais. No 'sistema operacional' do homem do sertão - menos binário que o nosso? - a ambiguidade, a contradição e o paradoxo tem lugar privilegiado e, assim como na obra de Rosa, "Tudo é e não é”: Eu não acredito, não. Mas eu tenho que acreditar também. / Pra mim existe. Existe e não existe. / Os maus também têm que ter um lugar bom, não é? / Nunca saí daqui, não. Que se a gente for andar, quer ir em muitos lugares.

O mito e a fantasia, bem como os demais níveis de realidade que transcendem a lógica racionalista, acham-se presentes na obra rosiana, dos relatos de Sagarana às estorietas de Tutaméia, de formas as mais variadas: superstições e premonições, crença em aparições, devoção a curandeiros e videntes, misticismo e temor religioso, como o temor ao diabo, e certa admiração pelo mistério e o desconhecido. Tais elementos constituem parte integrante do complexo mental do homem do sertão, e não podem, segundo o autor, estar ausentes de suas narrativas, pois, como ele próprio afirma em sua entrevista a Lorenz, "para entender a "brasilidade" é importante antes de tudo aprender a reconhecer que a sabedoria é algo distinto da lógica". (COUTINHO, 1995: p.20)

Nesse sentido, talvez possamos pensar no "complexo mental do homem do sertão" como uma espécie de "reserva ecológica do pensamento selvagem" - lugar que seria reservado à arte, segundo Lévi-Strauss - lembrando que "o contrário do “pensamento selvagem" é o pensamento domesticado em vista de obter um 
rendimento". ${ }^{18}$ Se um entrevistado diz acreditar que o aquecimento global é lenda e que seus antepassados viviam debaixo d'água, não importa que essa afirmação seja absurda ou até risível. Ela é, de todo modo, uma multiplicação dos possíveis, e interessa-nos não apenas enquanto narrativa - e não pela veracidade de seu conteúdo - mas também como expressão disso que estamos chamando um outro diferente do meu - sistema operacional. Desse modo, a experiência deste trabalho pode ser vista, em alguma medida, como um "exercício de descolonização" de nosso próprio pensamento abrindo-o a outras possibilidades, outras imagens do mundo, outras mentes. 


\section{LISTAS, SERIES, CONJUNTOS}

Em suas remotas páginas consta que os animais se dividem em:

a) pertencentes ao Imperador,

b) embalsamados,

c) amestrados,

d) leitões,

e) sereias,

f) fabulosos,

g) cães soltos,

h) incluidos nesta classificação,

i) que se agitam como loucos,

j) inumeráveis,

k) desenhados com um finíssimo pincel de pêlo de camelo,

l) etcétera,

m) que acabam de quebrar o vaso,

n) que de longe parecem moscas.

Jorge Luís Borges

$\mathrm{O}$ ato de listar é uma prática antiga, uma espécie de 'efeito colateral' da escrita, associada aos mais elementares procedimentos científicos: quantificar, catalogar, classificar. Nos relatos dos viajantes naturalistas, assim como nas cadernetas de Rosa, as listagens são recorrentes. Há listas de nomes de vacas (167!), de tipos de abelhas e marimbondos, de palavras usadas pelos ciganos e até de coisas que "Joãozinho vende:

1) Breu de borá - é uma massa puxenta, que a abelha forra o fundo do cortiço.

Serve para fazer estopamento (calafate) de canôas e lanchas. (breu de borá)

2) Fava de umburana

3) Resina de jatobá

4) Fava de sucupira (semente)

5) Papagaios, periquitos, pássaros-pretos (toda qualidade de passarinhos)" (ROSA, 2011: 63)

O mesmo procedimento enumerativo aparece na escrita ficcional transfigurado pela extraordinária sensibilidade poética do autor. A “enumeração 
de palavras pertencentes à mesma classe gramatical e ao mesmo campo semântico, introduz uma ruptura na estrutura sintagmática do discurso, e contribui para uma espécie de neutralização da oposição entre prosa e poesia." Em “O recado do morro", podemos ver a paisagem descrita na forma de longas listas, de caráter inventariante, que reúnem os elementos em séries ou conjuntos.

"Agora, pelas penedias, escalam cardos, cactos, parasitas agarrantes, gravatás se abrindo de flores em azul-evermelho, azagaias de piteiras, o páu-d'óleo com raízes de escultura, gameleiras manejando como alavancas suas sapopemas, rachando e estalando o que acham; a bromélia cabelos-do-rei, epífita; a chita - uma orquídea; e a catléia, sofredora, rosíssima e rôxa, que ali vive no rosto das pedras, perfurando-as." 19

Em seres, coisas, lugares, as enumeracões também estão presentes de diferentes formas: nas falas dos entrevistados (ora, espontaneamente, como é o caso de Washington, ora provocadas pela entrevista); nas páginas da caderneta de Rosa que aparecem na tela (o roteiro da viagem e uma lista de tipos de marimbondos); e ainda nas listas manuscritas por sobre a imagem, uma espécie de registro resumido da fala.

Quarenta e um são os itens da lista de coisas que Washington vai cantar. A quantidade de elementos do conjunto aponta para um desejo - heroico e ingênuo de tudo abarcar, tudo incluir, um desejo de exaurir as possibilidades. Em seu discurso verborrágico, repleto de digressões e interpolações infinitas, podemos identificar traços do "modo maníaco" de pensar, conforme descrito por Biswanger, médico do historiador da arte Aby Warburg, em citação de Didi-Huberman:

(...) uma "prolixidade linguística" que usa e abusa da compressão ou da concisão das formulações; uma predileção imoderada pelas séries em que são abundantes as rimas, as assonâncias, as semelhanças entre as palavras ( alternadamente próximas da poesia e dos disparates); o uso recorrente de retificações, inversões e negações; uma rarefação característica de formas verbais (...) em prol de uma acumulação de substantivos; (...) a alta complexidade 
das significações que pode alojar-se no "empobrecimento da articulação sintática"; o caráter lúdico, às vezes poético, dos trocadilhos ou dos "termos bombásticos" emitidos como profecias. (DIDI-HUBERMAN, 2013:397)

A mesma obsessão inventariante que incide nas criações verbais de nosso personagem parece incidir também nas suas criações materiais. Comportando-se ora como "colecionador", ora como "alegorista", assim como descritos por Walter Benjamin, Washington empreende uma "luta contra a dispersão em que se encontram as coisas no mundo", retirando os objetos de suas relações funcionais para inseri-los em novos arranjos, novos conjuntos:

\begin{abstract}
Aí, ó, o que você tá vendo aí, eu adquiri catando essas coisa aí na rua. Fui catando esses negócio e pendurando aí. Fui catando, trazendo e colocando. Catando, trazendo $e$ colocando. E assim eu tô indo, e vai ser assim até o fim, até eu morrer. É assim que eu vou fazendo. Porque eu sou artista, então Deus me deu essa inspiração de fazer essas coisas.
\end{abstract}

No terreno em que fica o barraco de barro em que ele vive, tudo - o canteiro, a cerca, o portão, a fachada, o jardim - está construído, disposto, agrupado, exibido, combinado de um modo preciso, criterioso e esteticamente impactante, e parece fazer parte de uma grande obra de arte na qual ele trabalha continuamente. $\mathrm{Na}$ parte externa da casa, uma espécie de museu do mundo, os objetos são agrupados por afinidades segundo o material de que são feitos ou sua função utilitária. Há desde conjuntos de ossos e caveiras de bois a esculturas - com direito à base, inclusive - como o "fogãozinho de lenha". No "fogãozinho de lenha" podemos ver, harmoniosamente arranjados, um prato esmaltado, uma frigideira, uma panela de ferro, uma garrafa térmica, um bule e, inesperadamente, um pedal de bicicleta e uma galocha. A presença de elementos estranhos à logica do conjunto - que, no entanto, subjaz - faz a organização, tão insistentemente perseguida, escapar, promovendo um salutar desarranjo da ordem análogo ao que acontece em suas construções verbais.

$\mathrm{Na}$ fachada do casebre, estão pendurados objetos metálicos, a maioria de ferro, enferrujados, alguns de alumínio, que Washington apresenta e nomeia, um a 
um: A lima é pra comer a enxada, o serrote, o disco da maqueta, o arreio velho do cavalo, a foice. Ao dizer $o$, e não um, é como se aqueles fossem objetos exemplares, a matriz de todos os outros, e estivessem recebendo seus nomes, pela primeira vez.

\begin{abstract}
Mas é com nosso sopro que nos dirigimos a tudo, com a voz que o frágil fole da garganta emite, com o hálito que carrega nossas enzimas, é com o pequeno vento de nossa língua que chamamos o vento verdadeiro. Mais do que comer, correr ou flechar a carne alheia, mais do que aquecer a prole sob a palha, nós nos sentamos e damos nomes, como pequenos imperadores do todo e de tudo. (Ramos. 2008: 20)
\end{abstract}

Ainda na fachada, deslocado, encontra-se um CD, com a face brilhante para cima, cuja participação no conjunto pode ser atribuída, talvez, à qualidade do brilho que ele partilha com os metais.

Os objetos com os quais Washington constrói suas ‘esculturas' são memória do mundo - rastros, resíduos, restos de outros tempos e de outros seres, anônimos e infames como ele. Mas, através de um gesto - recolher, agrupar, ordenar - os objetos são restituídos à vida, dotados de significado, dignificados. Muitos escritores e artistas contemporâneos, de diferentes contextos culturais - como Ítalo Calvino e Georges Perec ou Arthur Bispo do Rosário e Arman - têm se dedicado ao exercício criativo das taxonomias, com o propósito, muitas vezes, de criticar os sistemas legitimados de organização do mundo. Em Washington, todavia, arquivar, colecionar, agrupar, classificar e nomear parece ser uma tentativa de se constituir através dos objetos, como se ele, não muito diferente de nós, esperasse das coisas que elas the dissessem quem ele é. 


\section{FALAR e OUVIR, LER e ESCREVER}

Todas as coisas são palavras lidas Na língua em que Algo ou Alguém, noite e dia,

Escreve essa infinita algaravia

Que é a história do mundo.

Jorge Luís Borges

Suponhamos que diante de uma visão estupenda saiam nossos sentidos fora de sua esfera e inaugurem o ver com os ouvidos e o ouvir com os olhos.

Pe.AntônioVieira

Eles não me compreendem: eu não sou boca para esses ouvidos.

Zaratustra/Nietzsche

As formas diversas sob as quais este trabalho se manifesta são expressão do desejo de explorar a palavra em suas múltiplas dimensões. Fala e escuta, leitura e escrita foram não apenas os meios através dos quais pudemos nos aproximar - e construir - o objeto desta pesquisa como também, simultaneamente, objetos de reflexão, em si mesmos.

A reflexão sobre a linguagem e, mais especificamente, sobre a fala, nos remete, de imediato, a um território mítico, o ato da Criação, assim como aparece na tradição bíblica. No Gênesis, o mundo começa com um sopro. É a palavra de Deus que cria o mundo - e não suas mãos ou sua imaginação. Deus diz as coisas e, num segundo movimento, as nomeia. Daí, que é somente na palavra de Deus que seria possível encontrar uma espécie de identidade original entre a palavra e a coisa.

3. E Deus disse $\S$ seja luz $\S \S \S$

E foi luz

4. E Deus viu $\S$ que a luz $\S$ era boa $\S \S \S$

E Deus dividiu $\S \S$

Entre a luz $\S$ e a treva 
5. E Deus chamou à luz $\S$ dia $\S \S$

e à treva $\S$ chamou noite $\S \S \S$

E foi tarde e foi manhã $\S$

dia um ${ }^{20}$

Esse "ritmo ternário" da Criação - Deus disse / Assim se fez / Ele chamou sofre uma alteração, no sexto dia: a criação do homem não se dá pela palavra. Único, entre todos os seres, não-nascido da palavra, o homem é feito de terra - “em toda a história da criação, essa é a única passagem em que se fala da matéria na qual o Criador expressa sua vontade. ${ }^{21}$ Deus não diz o homem mas fá-lo, à sua imagem e semelhança, e deposita nele seu poder criador, o dom da língua, que o eleva acima da natureza e com a qual passa a nomear as coisas.

26. E Deus disse $\S \S$

façamos o homem $\S$ à nossa imagem $\S$

conforme-a-nós-em-semelhança $\S \S \S$

E que eles dominem sobre os peixes do mar

E sobre as aves do céu $\S$

E sobre os animais-gado $\S$ e sobre toda a terra $\S \S$

E sobre todos os répteis $\S$ que rastejam sobre a terra

27. E Deus criou o homem $\S$ à sua imagem $\S \S$

à imagem de Deus $\S$ ele o criou $\S \S \S$

Macho e fêmea $\S$ ele os criou.

A evocação dessa cena de origem e as reflexões dela derivadas, foram trazidas pelo ensaio "Sobre a linguagem em geral e sobre a linguagem dos homens", de Walter Benjamin. Nesse texto, escrito em 1916, quando o autor tinha apenas 24 anos, e nunca publicado em vida, o incomum pensador desenvolve uma reflexão baseada na ideia - problemática e instigante - da língua "como uma realidade

\footnotetext{
${ }^{20}$ Bere'shith, A Cena da Origem. Transcriação Haroldo de Campos

${ }^{21}$ BENJAMIN.2013,60
} 
última, inexplicável e mística que só pode ser considerada em seu desenvolvimento". Embora não seja nosso desejo assumir, integralmente, esse pressuposto, parece-nos igualmente impossível, ou, pelo menos, indesejável, rejeitá-lo por completo, uma vez que as ideias e o tom do ensaio se mostram em perfeita consonância com os objetos envolvidos em nossa reflexão. Obviamente, o que se pretende - aqui, como lá - não é tomar a Bíblia enquanto verdade revelada, e nem tampouco realizar uma interpretação do texto bíblico. Valemo-nos do Gênesis, assim como nos valemos, ao longo do trabalho, de textos poéticos e literários, como meios fertilizadores da reflexão. Como no interior da obra de Rosa, o mito é tratado, aqui, como uma entre outras possibilidades de apreensão do real. Numa carta ao tradutor italiano Edoardo Bizzarri, Rosa escreve:

Ora, Você já notou, decerto, que, como eu, os meus livros, em essência, são anti-intelectuais - defendem o altíssimo primado da intuição, da revelação, da inspiração sobre o bruxolear presunçoso da inteligência reflexiva, da razão, a megera cartesiana. Quero ficar com o Tao, com os Vedas e Upanixades, com os Evangelistas e São Paulo, com Platão, com Plotino, com Bergson, com Berdiaeff - com Cristo, principalmente. (ROSA, 2003:90)

A supremacia da phoné (fala) com relação à escrita atravessa a história do pensamento ocidental, da filosofia de Platão à Linguística de Saussure. No Fedro, de Platão, a phoné é considerada "símbolo do estado de alma" e mantém com esta "uma relação de proximidade essencial e imediata", enquanto que a escrita é considerada uma derivação, mero instrumento de fixação no espaço exterior da fala cuja "essência" é interna. Inseparável do logos, a phoné está sempre associada ao dentro, à mnemè (memória ativa, viva, interior). Assim, a oposição dentro / fora acabou convertendo-se na matriz de uma cadeia de oposições que pressupõe a seguinte relação: fala $=$ dentro $=$ inteligível $=$ essencial $=$ verdadeiro, enquanto escrita $=$ fora $=$ sensível $=$ aparência $=$ falso. Desse modo, para Platão, o conhecimento filosófico só poderia efetuar-se através da phoné, da presença viva do ser no presente de seu discurso, nunca através da escrita, não-presença. 
Num estágio já muito avançado do trabalho, voltamos à ilha de edição com o objetivo de vasculhar o material bruto, 'pela última vez', atrás de coisas que pudessem servir na criação do 'texto'. Ao ouvirmos pela enésima vez o mesmo material, nos deparamos com uma longa história contada por um dos entrevistados sobre um encontro com o capeta:

Eu tava acabando de descer uma serra - só via fogo saindo dos cristal... - e tava um cavaleiro, ali. Aí eu pensei: eu vou correr de modo que eu vou pitar e beber um gole mais ele. Eu tava com um litro de pinga na sela e um cigarrão de palha pronto. Aí, eu apertei meu cavalo, meu cavalo saiu numa disparada, ai quando ia pra chegar perto, era só eu dar uma piscada, e o cavalo dele batia como daqui lá naquela cerca, quase. Uma vez, duas, ai eu pensei: vai matar meu cavalo correr atrás dele assim. Quando eu dei de virar pro outro lado, ele desceu direto. E eu só escutando a zoeira. Aí eu pensei: aquele baiano não quis falar nada comigo e nem me esperar foi por ruindade. Aí, eu sentei, bebi um gole - primeira vez que eu bebi um gole na estrada - tô pitando, lá, e o meu cavalinho tá só andando em roda de mim... E eu segurando a corda, e ele andando em roda com a corda. Aí eu: - "O quê que é isso cavalo? Bobo! Você nunca viu o capeta, não!?" Aí o cavalo virou bicho deveras em volta de mim. E eu: uai, vai ver que esse trem aqui pode ser o capeta mesmo! Porque o cavalo tá desse tipo! Eu falei com ele e ele ficou com mais medo! Nisso aumentou a zoeira do estrado do pé do outro cavalo, o que foi diante de mim...Aumentou a zoeira... Poc, poc, poc... Uma altura! Só via a zoeira do cavaleiro na estrada. E o cavalinho meu também tava vendo. Mas eu falei com ele que ele arregalasse os olhos porque eu não conhecia o capeta, não. E o cavalinho meu foi ficando doido deveras. E eu: aquilo é o capeta, não é possível. Ai eu pensei, pensei... O que é que pode ser isso? Será que eu não tô muito com Deus? E o trem pra mim não tava bom mesmo não que o povo tava de má vontade demais comigo. Aí eu peguei o cavalo e fui embora. Cheguei em casa e fui dormir dentro do paiol. No outro dia, o cavalo amanheceu com os olhinho arregalado, a barriga vazia, fininho... Parece que dormiu amarrado num pau. Aí eu peguei ele, fui lá no córrego, banhei ele, pus um sal pra ele, olhei a mão dele tava só um machucão, mas não tava ruim, não. - "Esse cavalo tá sofrendo." E eu:- "É medo, moço." - "O que que esse cavalo tem que tá fininho desse jeito?" - "É medo. $O$ cavalo tá com medo, ele tá sofrendo." - "O que que foi?" - "Foi assombração. Ontem. E o trem não era mole, não. O trem era feio. Assustou demais mesmo." Ai eu rezei uma oração mais forte, mais depressa, e pedi a Deus pra não 
deixar as coisas feias me pegar, não. Pra manter as coisa feia longe. Pra ir afastando as coisas feia também. Ah, isso, rezo. Rezo p'ra as almas, toda noite, e de menhã rezo pr'a mim...Pego com Deus. Ai desacismou o cavalo $e$ desacismei eu também. Que eu também tava meio assombrado.

Como era possível que aquela estória tivesse estado sempre ali? Como explicar que uma estória tão curiosa e bem contada tenha passado despercebida em todas as incontáveis vezes em que o material foi assistido? Talvez o fato de ela estar encoberta pelas hesitações, digressões e repetições características da fala - o que, no entanto, se aplica a todo o material. Talvez o fato de o capeta ser algo que nunca se dá a ver de forma explícita, inequívoca, direta, de ser alguma coisa sempre ambígua, cuja existência se deduz, a partir de certos indícios, certos sinais. Talvez o fato do ouvinte ser incapaz de 'ler' esses indícios, perceber esses sinais ou, ainda, o fato de um encontro dessa natureza - com o capeta - ser algo tão fora do nosso repertório que nos faltam os receptores adequados para escutá-la.

De qualquer modo, o episódio parece bastante exemplar do modo como a escuta é movediça, deslizante, e seu objeto, de difícil apreensão. É sempre possível ouvir diferente, ouvir mais, ouvir menos, não ouvir. Porque ouvir varia segundo quem, quando, e onde se ouve, no mínimo. E, para tudo que fala, é preciso que haja ouvidos para ouvir.

"Quando o visitante do Hospício de Alienados atravessava uma sala, viu um louquinho de ouvido colado à parede, muito atento. Uma hora depois, passando na mesma sala, lá estava o homem na mesma posição. Acercou-se dele e perguntou: "Que é que você está ouvindo?" O louquinho virou-se e disse: "Encoste a cabeça e escute." O outro colou o ouvido à parede, não ouviu nada : "Não estou ouvindo nada." Então o louquinho explicou intrigado: "Está assim há cinco horas."

Afinal de contas, a parede são vertiginosos átomos, soem ser. Houve já até, não sei onde ou nos Estados-Unidos, uma certa parede que irradiava, ou emitia por si ondas de sons, perturbando os rádio-ouvintes etc. $\mathrm{O}$ universo é cheio de silêncios bulhentos. O maluquinho podia tanto ser um cientista amador quanto um profeta aguardando se completasse séria revelação. Apenas, nós é que estamos 
acostumados com que as paredes é que tenham ouvidos, e não os maluquinhos." (ROSA, 1985:15,16) ${ }^{22}$

Os gregos antigos, anteriores ao surgimento da filosofia, que "serviam no santuário de Zeus em Dodona", ${ }^{23}$ ouviam, supostamente, no ruído do vento que soprava nos carvalhos, as mensagens do oráculos. Um sentido se comunicava diretamente, através de um sopro. Uma escrita sem palavras, quase imaterial, uma escrita "menos que escrita", como nos fala Rancière, em oposição a uma escrita "mais que escrita", que seria aquela traçada na própria textura das coisas, nos sulcos das pedras, nas espirais das conchas, nos cascos das tartarugas, nas manchas dos tigres.

Esses dois extremos, de um lado, o "sonho de uma apresentação imediata, não mimética, do sentido no sensível" ${ }^{24} \mathrm{e}$, de outro, o sentido gravado na matéria, “indelével e infalsificável”, são como marcos numa paisagem no interior da qual buscamos 'escutar' a voz do morro.

No conto, é apenas a Gorgulho, "um velhote grimo, esquisito, que morava sozinho dentro de uma lapa, entre barrancos e grotas", 25 que "devia de ouvir pouco, pois a comitiva já quase o alcançara e ele ainda não dera por isso", ${ }^{26}$ que o morro revela sua voz, que permanece inaudível para os demais. "Esse habitante do limiar que separa e une natureza e cultura é capaz de auscultar a linguagem em estado selvagem e de retransmiti-a para outros “deficientes”, responsáveis pela articulação progressiva do recado." 27

Essa linguagem inarticulada, em estado selvagem, na qual o morro emite seu recado, poderia ser pensada como uma língua aquém da língua, uma língua anterior ao código. Entretanto, o morro é "Belo como uma palavra"; a estrada, "como de costume, é um S, que começa grande frase"; e o Gorgulho "parecia um garatujo". Assim, a garatuja, a letra, a palavra e a frase nos levam a pensar não numa linguagem anterior ao código, mas num código - inscrito, talvez, nas coisas -

\footnotetext{
${ }^{22}$ O trecho em itálico é uma citação, feita por Rosa, de Andorinha, Andorinha, de Manuel Bandeira

${ }^{23}$ PLATÃO. 2016, p.193

${ }^{24}$ RANCIÈRE, 1995. p.10

${ }^{25} \mathrm{RM}: 37$

${ }^{26} \mathrm{RM}: 38$

${ }^{27}$ PRADO JR. 1985, p.220
} 
anterior à própria linguagem. Nesse sentido - e desejando não encerrar o conto numa única possibilidade de leitura - podemos ver "O recado do morro" como a concretização de uma teoria da linguagem, segundo a qual a escrita precede a oralidade. "O mundo é um livro e nele está depositada, anterior a toda escrita, uma Escritura primordial que é preciso dizer novamente." 28

Ser capaz de ouvir o recado do morro equivale, então, a 'ler' sua mensagem, quer em sua forma bruta - a da emissão original - quer através da cadeia de traduções formada pelos sete recadeiros, ou ainda, na sua forma final, de canção, que precisa ser lida pelo protagonista. Mas se ler é questão central na narrativa, "essa faculdade não se confunde com a competência letrada.". 29

Começamos a vislumbrar que o analfabetismo não indica apenas uma carência e que ele pode significar uma virtude e um privilégio. Simetricamente, começamos a perceber que o uso instrumental da língua, a sua domesticação através da escrita pode aparecer como uma perda ou um esquecimento. Na situação irônica que contrapõe o letrado ao iletrado, o Saber se encontra do lado mais inesperado: não dominar a linguagem, não saber utilizá-la, é devolvê-la à sua verdade e à sua vocação mais primitiva. Numa fórmula breve: ler em profundidade ( o "verivérbio") só é possível para quem não sabe ler a superfície da letra. (PRADO JR, 1985:199)

Falada, não fixada no papel, a linguagem serve à dúvida, à variação, à oscilação de sentido. Mas talvez seja ilusão acreditar que, uma vez escrita, ela se torne inteiramente imune a esses deslizamentos e que seu sentido esteja garantido de forma absoluta. Em "O recado do morro", podemos sentir essa instabilidade do terreno em que se move a escrita quando, por exemplo, o autor experimenta diferentes grafias para um mesmo som - xôiz' / chôiz' - ou variações de som para um mesmo nome - Olquiste/ Alquiste / Alquist - ameaçando a confiança do leitor na escrita como algo fixo, imutável. Também o fato de, no conto, um mesmo personagem aparecer chamado por diferentes nomes - Zaquias ou Catraz ou

\footnotetext{
${ }^{28}$ PRADO JR. 1985, p.224

${ }^{29}$ WISNIK.1998, p.161
} 
Qualhacôco; Jubileu ou Santos Óleos ou Nominedômine - parece contribuir para essa sensação de instabilidade da escrita.

E se a escrita, onde julgávamos poder encontrar solidez, é movente, a experiência leitora é um "ultrapassamento da coisa escrita", como nos diz Sartre. Nesse sentido, podemos dizer da leitura o mesmo que já dissemos da escuta, ou seja, que ela varia segundo quem, onde e quando se lê, pelo menos. "A leitura é um outro, e não outra face do idêntico, mas é nesse outro que se dá o significado do texto; portanto, ele não é um procedimento distinto da escritura, mas é nela que esta se consuma." 30

$\mathrm{Na}$ contramão do pensamento que considera a escrita como mera duplicadora da fala originária, representação secundária da linguagem falada, este trabalho escolhe alinhar-se às ideias de Jacques Derrida e pensar a escrita como um ato de força ou, nos termos do autor, uma afirmação do filho contra o pai, em cuja ausência a palavra ousa significar.

Antes de serem transformadas em escrita, as 'notas de campo' deste trabalho foram registradas por meios audiovisuais, mais capazes, talvez, de apreender a multissensorialidade e a multidimensionalidade da vida vivida do que a página bidimensional. Embora comparáveis à escrita em vários aspectos - são reiteráveis, abolem a presença de quem traz a voz e se desenrolam em espaços artificialmente construídos - os meios eletrônicos distinguem-se da escrita por fixar a voz e a imagem do falante endereçando-se, além do olho, também aos ouvidos. Mas, ao tornarem-se reiteráveis, abolindo seu caráter efêmero, imagem e voz se tornam desencarnadas, abstratas, vítimas de uma alienação particular ${ }^{31}$, tão distintas e distantes da experiência vivida quanto a escrita.

Nesse sentido, podemos pensar que o presente da filmagem, aquilo que se produz na e pela presença da câmera é o único momento-único, entre todas as etapas da produção de um filme. Esse momento - que será recortado, recombinado e reproduzido, infinitamente - permanecerá para sempre irrecuperável em sua

\footnotetext{
${ }^{30}$ SANTIAGO.1976: p.54 (Glossário de Derrida)
} 
dimensão de performance. O peso, o cheiro, o calor, o volume real do corpo do qual a voz é apenas expansão perdem-se, irremediavelmente, em todas as outras formas assumidas pelo material. Contudo, o que todas essas outras formas ambicionam, quase sempre, é trazer essa corporeidade, esse peso, esse cheiro que fizeram parte da experiência para aqueles que não a viveram.

Esse desejo de guardar as marcas do momento vivido, de capturar, além da fala, o corpo que fala, está lá: no longo tempo que Seu Mauro demora para lembrar a canção; nos dedos nervosos que ele cruza e descruza, sem parar; na expressão com a qual Seu Tonico conclui a frase inconclusa: No mais, té logo e benção! Nunca mais eu... Contudo, o que se buscava, desde o início, no documentário, era a experiência já transfigurada, de 'segunda mão', o acontecimento contado. Em “A Imagem de Proust", Walter Benjamin afirma: "um acontecimento vivido é finito ou pelo menos encerrado na esfera do vivido, ao passo que um acontecimento rememorado é sem limites, pois é apenas uma chave para tudo que veio antes ou depois". ${ }^{32}$ E acontece ainda, em alguns momentos do filme, que o contado é transformado em escrito, sofrendo uma nova codificação.

A ideia de escrever a fala sobre a imagem do falante e ir sumindo com a imagem, gradativamente, em fade out, até ficar só o texto na tela surgiu, como resultado da preocupação com a inteligibilidade das entrevistas. Mas, uma vez escrita, letra branca sobre tela preta, o efeito que se produzia era outro, distinto do da fala proferida. Ao se descolar da imagem do enunciador, o enunciado parecia dotado de uma potência particular e o que se deixava ver, afinal, era a própria diferença entre os dois sistemas de signos. Cabia pensar, ainda, no efeito exercido pela oralidade e pela escrita inclusive sobre o próprio sentido. Além disso, vista ao lado de trechos extraídos do conto - escritos com a mesma letra branca sobre a mesma tela preta, sem aspas - a fala comum deixava ver a sua feição literária.

A partir daí, passamos a explorar, de forma consciente, essa disjunção entre imagem e voz, som e letra, buscando diferentes combinações: ouvir e ver (a imagem do falante); ouvir sem ver (voz em off); ouvir e ler (a fala escrita na tela); ler sem ouvir. Em “A triste estória de amor de Seu Tonico”, por exemplo, a narrativa nos chega, primeiro, sob a forma escrita (junto com a voz em off), um pouco como se

32 BENJAMIN, 1994: p.37 
fosse uma estória sem dono, uma novela de rádio, e só num momento posterior, depois que se completa a página-tela, vemos a imagem do falante.

Da experiência de transcrição da fala para a tela, no filme, acabou surgindo a ideia da construção de um texto como objeto independente das imagens. Enquanto no documentário, porém, a escrita é uma duplicação, um espelhamento da fala - e mesmo assim, isso representa um salto - no processo de construção do 'texto', a fala se desvencilha inteiramente de seus falantes e a escrita reivindica autonomia e liberdade para "inseminar-se e disseminar-se".

O trabalho de edição exige que se assista a um mesmo material infinitas vezes. Nesse processo, torna-se praticamente inevitável saber de cor as falas gravadas e repetidas à exaustão. De tanto ouvir, então, chega um momento em que deixa-se de escutar, realmente. Nesse movimento, em que a repetição promove um esvaziamento da escuta, foi preciso escrever para ser capaz de ouvir novamente.

Podemos pensar, então, de trás pra frente, que o que se operou neste trabalho foi uma escuta que produziu uma escrita que nos reenviou à escuta. E, se recuarmos um pouco mais, podemos imaginar que essa escuta - das entrevistas - foi produzida, por sua vez, pela leitura do conto. Nosso contato com a "língua brasileira do sertão" se deu, primeiro, através da literatura, e foi isso o que possibilitou a escuta das entrevistas. Assim, teríamos um movimento através do qual a leitura - a literatura - produz uma escuta, que produz uma escrita, que nos reenvia à escuta. 


\section{O EXPERIMENTO DE ESCRITA}

A contribuição milionária de todos os erros.

Oswald de Andrade

A substância do próprio tutano tornada citação

Waly Salomão

O experimento de escrita "Tudo significa, as coisas" combina, de forma indiscriminada, as vozes dos moradores do Morro da Garça, a de Guimarães Rosa e a minha própria. O recado emitido pelos morrenses aparece no 'texto' transfigurado e deformado, através de uma cadeia de traduções (oral/audiovisual/escrito) mas - acreditamos - guardando a marca dos recadeiros envolvidos. Em vez de falar sobre o 'outro', o que interessa, nessa experiência, é falar com o 'outro'; em vez de emprestar a palavra ao 'outro' - do lugar do possuidor - tomar emprestadas as palavras do 'outro'. Uma espécie de "literatura simétrica", talvez, numa aproximação com a "antropologia simétrica", tal como pensada por Eduardo Viveiros de Castro. Mas se esse, aqui chamado, 'outro' deve a sua 'outridade', em grande medida, a uma privação - o letramento - isso não quer dizer que essa falta seja uma fraqueza:

O recurso aos modelos da linguagem rústica não é fruto de uma escolha ocasional: essa linguagem, que desconhece a codificação estrita de uma gramática que visa à eficácia operacional, é privilegiada para quem quer retornar àquele brilho das palavras que precede toda ação e prefigura as nervuras do imaginário. É o analfabeto, como o poeta, que consulta o volume interno das palavras, que interroga as franjas que as cercam, na esperança de alimentar a sua sabedoria. Aquém da escrita é que se pode encontrar uma experiência da linguagem semelhante àquela que a literatura procurará restituir: esperança de captar no puro movimento das palavras, no domínio exíguo que instauram, a verdade do mundo e da experiência." (PRADO JR, pág: 224 ) 
O fato de tomar a fala de pessoas comuns, semiletradas, como matéria-prima para um texto de ficção significa enxergar ali, naquelas palavras, uma potência comparável à da escrita institucionalmente aceita como poética. Esse procedimento implica, no limite, em interrogar a própria especificidade do literário. A ideia de que não há literatura $\mathrm{em} s i$; de que nem a literatura nem a poesia são essências, parece, atualmente, bastante bem aceita. Isso não significa, porém, que a linguagem literária não se distinga da linguagem comum. "Admitimos que as palavras de um poema não desempenham o mesmo papel e não mantêm as mesmas relações que as da linguagem comum. Mas uma narrativa escrita na prosa mais simples já implica uma mudança importante na natureza da linguagem". ${ }^{33}$

Em "O narrador: considerações sobre a obra de Nikolai Leskov", texto de 1936, Walter Benjamin descreve dois tipos arcaicos de narradores, anteriores à escrita: o camponês, que seria o detentor da memória da comunidade, do saber tradicional adquirido no trabalho sedentário, e o marinheiro, que traz o saber de terras distantes. Mas se os camponeses e os marinheiros foram os primeiros mestres da arte de narrar, foram os artesãos que a aperfeiçoaram. "A narrativa, que floresceu num meio de artesão, é ela própria, num certo sentido, uma forma artesanal de comunicação baseada no intercambio de experiências." ${ }^{\text {34 }}$ A experiência que passa de pessoa a pessoa é a fonte a que recorreram todos os narradores. É da experiência - a sua própria e a dos outros - que o narrador retira o que conta. Já as coisas narradas, por sua vez, são incorporadas à experiência dos ouvintes que adquirem, assim, o dom de narrá-las. Se o romancista escreve porque lê, como nos diz Roland Barthes, podemos afirmar que o narrador narra porque ouve. Assimilando à sua substância mais íntima aquilo que foi contado, o ouvinte transforma-se em potencial narrador. Contar histórias sempre foi a arte de contá-las de novo, "essa lenta superposição de camadas finas e translúcidas, que representa a melhor imagem do processo pelo qual a narrativa vem à luz do dia, como coroamento das várias camadas constituídas pelas narrações sucessivas."35

\footnotetext{
33 BLANCHOT.1997: 77

34 BENJAMIN. 1994: 206

${ }^{35}$ BENJAMIN, W.1994:206
} 
Segundo Walter Benjamin, essa arte da narrativa estaria - já na época em que o texto foi escrito - em extinção, seja porque "as ações da experiência estão em baixa", seja porque as experiências estão deixando de ser comunicáveis, ou ainda porque perdemos a faculdade de intercambiá-las. Na modernidade, quando "ninguém mais fia nem tece", as comunidades de ouvintes desaparecem e, com elas, as condições para o florescimento da arte de narrar.

Numa região predominantemente rural como é a de Morro da Garça, porém, podemos imaginar, num tempo não muito distante, essa comunidade de ouvintes formada por vaqueiros sentados ao redor de uma fogueira, numa rancharia, por exemplo, ou por trabalhadores debulhando milho num paiol. Embora os sinais da modernização sejam claramente visíveis, atualmente, na região, a comunidade conserva, ainda hoje, fortes traços arcaicos - na língua, nas práticas, no imaginário - e, nesse contexto, a arte da narrativa parece sobreviver.

Diferente do romancista, cuja voz é a de um sujeito isolado, o narrador fala por uma comunidade e suas narrativas têm caráter generalizante, exemplar, arquetípico. "A triste estória de amor de Seu Tonico", por exemplo, é uma típica estória de amor com vários de seus clichês: o amor proibido, o plano de fuga, o desencontro, a falta de comunicação... Seu Nonô, por outro lado, com suas 153 namoradas, é uma espécie de D. Juan do sertão, a encarnação do tipo conquistador, que aparece também em "O recado do morro", na figura de Pedro Orósio. Na narrativa dos morrenses, podemos observar também uma espécie de exageração dez anos eu fiquei sem esquecer dela ou nunca mais nada prestou pra mim ou eu tive 153 namoradas! - que funciona como eficiente recurso narrativo. Para o narrador anônimo, o que importa não é "o puro em si da coisa", mas a própria narrativa e sua capacidade de causar impressão. A fim de impressionar o ouvinte, ele não se furta a recorrer ao extraordinário, ao sobrenatural, ao mistério, elemento "que a épica - na versão culta ou popular - tem a tradição de perscrutar",36

- E o cavalinho meu também tava vendo. Mas eu falei com ele que ele arregalasse os olhos porque eu não conhecia o capeta, não. E o cavalinho meu foi ficando doido deveras. E eu: aquilo é o capeta, não é possível! 
O processo de construção do texto "Tudo significa, as coisas" envolve, fundamentalmente, duas operações: tradução e montagem. A tradução é, simultaneamente, método e objeto de reflexão deste trabalho, atravessando-o de diferentes formas e em diferentes níveis. Indo ainda mais longe, podemos afirmar que este estudo é presidido pela ideia, tributária de Nietzsche, segundo a qual a linguagem é sempre, ela mesma, tradução.

Diferente das mensagens, que vão, diretamente, de um emissor a um receptor, num recado, esse trajeto é atravessado por um (ou mais) intermediário(s) e, nesse sentido, podemos pensar que a dinâmica da tradução (língua de partidatradutor-língua de chegada) se assemelha, de certo modo, à dinâmica do recado (destinador-recadeiro-destinatário). Em "O recado do morro", a transmissão do recado através dos sete recadeiros - e seus desvios paralelos - se configura também como uma cadeia de traduções:

Só Pedro Orósio às vezes capiscava, e reproduzia para frei Sinfrão, que repassava revestido p'ra seo Olquiste. E seo Jujuca também auxiliava de falar estrangeiro com frei Sinfrão - mas era vagaroso e noutra toada diferente de linguagem, isso se notava. Mas, depois, toda a resposta de seo Alquiste retornava, via o frade e Pê-Boi. Por tanto, todos então estavam nervosos, de tanta conconversa. ${ }^{37}$

São também operações tradutórias tanto a passagem da linguagem literária para a linguagem cinematográfica, como a passagem da oralidade para a escrita. No processo de tradução da oralidade - capturada, originalmente, por meios audiovisuais - para a escrita podemos identificar diferentes etapas. Num primeiro momento, imediatamente após a viagem, a tradução foi apenas uma duplicação, um espelhamento da fala. Manuscritas, incompletas, essas transcrições eram uma espécie de mapeamento do material que incluía informações técnicas como números de rolos, cartões e dias de filmagem. Mas a 'simples' tarefa de traduzir o som em letra é, muitas vezes, menos simples do que parece. Em alguns momentos das entrevistas gravadas, apesar de todos os recursos de que lançamos mão - 
ralentar a velocidade do áudio, fazer leitura labial frame a frame, etc - não conseguimos identificar o vocábulo e, às vezes, nem distinguir o som. Para essas palavras, que permaneceram durante muitos meses seguidas de um ponto de interrogação, cuja grafia e sonoridade oscilava a cada nova versão do 'texto', a solução nos foi sugerida pelo próprio Rosa.

A grafia para alguma coisa entre bom humor e bom amor - aquilo que é necessário para não deixar a tristeza chegar - foi encontrada no nome da fazenda Bõamor, que aparece no conto. A erva, cujo nome não consegui entender, aparece grafada ora como quituque, ora como kitoque, ou seja, diferente do ponto de vista gráfico e sonoro, enquanto quiuquiu e enlerou figuram no 'texto' do modo como fui capaz de ouvir. Ao transcrever arreminar, imaginei estar diante de uma palavra inventada, mal pronunciada ou mal entendida. Mas uma busca ao dicionário revelou o sentido perfeitamente coerente com o uso: tornar-se irado, enfurecido, encolerizado. Eu fui dar conselho / Pros dois não brigar / São Judas achou ruim /Quis arreminar/ acabou com a festa /não pude dançar...

Dando prosseguimento ao jogo com o som e a letra, decidi, no experimento de escrita, usar, pontualmente, a grafia obsoleta de algumas palavras como pêlo, pára, idéia. Esse procedimento não é - apenas - um modo de disseminar falsas pistas para enganar o leitor-detetive interessado em saber quem escreveu o quê, mas também a simulação de um procedimento usado por Rosa que continuou a escrever dansa, mesmo depois que a ortografia passou a considerar dança a forma correta. A codaque que Seu Olquiste carrega a tiracolo não seria a mesma se fosse Kodak.

Posteriormente, durante o processo de edição, a tradução, ainda apenas duplicadora da fala, foi incorporada ao filme como recurso estético e narrativo. Mais tarde, com o experimento de escrita, a tradução passou a se constituir como uma recriação ou, na perspectiva de Haroldo de Campos, uma transcriação. O uso do termo equivale a dizer que o processo foi pautado, não por um ideal de fidelidade do escrito com o falado, mas pelo desejo de tentar recriar, em outro meio e com outros recursos, um efeito semelhante ao produzido pela fala: "E que do choque dessas palavras e dessas vidas ainda nos venha um certo efeito no qual se misturam beleza e assombro." 38 No lugar de um ideal, de fidelidade ou qualquer outro, a

\footnotetext{
${ }^{38}$ FOUCAULT. 1992:94
} 
reivindicação da autonomia da escrita baseada na convicção de que "Escrever é saber que o que ainda não se produziu na letra não tem qualquer outra morada, não nos espera como prescrição em qualquer entendimento divino. O sentido deve esperar ser dito ou escrito para se habitar a si próprio." 39

$\mathrm{Na}$ transformação da fala em fala ficta, optamos por corrigir as infrações da norma sobretudo nos casos de concordância verbal e nominal, sempre que essa intervenção não implicasse em exagerado prejuízo do ritmo e da sonoridade. Essa opção visava a evitar que o 'texto' soasse demasiadamente regionalista, ou, na pior hipótese, caricatural. Se a passagem à escrita exigia esse tipo de intervenção, era preciso, no entanto, evitar, simultaneamente, a higienização, a pasteurização, a domesticação da linguagem originalmente 'selvagem'. Evitar que a escrita recolocasse a língua nos 'trilhos', subtraindo-lhe, justamente, aquilo que, na fala, lhe confere vitalidade e frescor.

Segundo Eduardo Coutinho, ao contrário do que se supõe normalmente, as maiores inovações de Guimarães Rosa com relação à linguagem literária residem no campo da sintaxe. Entre os processos mais frequentemente utilizados por Rosa - e que podem ser identificados, em alguma medida, na fala dos entrevistados do filme - o autor aponta: a enumeração de palavras pertencentes à mesma classe gramatical e ao mesmo campo semântico; a inversão da ordem tradicional dos vocábulos e sintagmas na oração; e o uso de orações justapostas e construções elípticas, típicas da linguagem oral, revelando uma preferência acentuada pela coordenação sobre a subordinação. ${ }^{40}$

Em: todos foram Deus que escolheu pra eles a profissão, em vez de: "foi Deus que escolheu pra eles todos a profissão", podemos observar essa inversão de ordem cuja estranheza fere a percepção do leitor ou do ouvinte. Em: e chegava até o padre ir lá separar a briga delas, em vez de "e o padre chegava até a ir lá separar a briga delas" entendemos que é justamente nesse discreto deslocamento de lugar dos termos na frase que reside a força da formulação. E essa força se deve ao fato de que, ao contrariar a expectativa do leitor-ouvinte, ela obriga-o à desautomatizar o ato de ler ou ouvir reclamando uma presença alerta e participativa.

\footnotetext{
${ }^{39}$ SANTIAGO. 1976 (Glossário de Derrida)

${ }^{40}$ COUTINHO. 1995:16
} 
Os narradores de Morro da Garça engolem, invariavelmente, a preposição dos verbos transitivos indiretos. Em vez de "entrego a você", "aprendi a brigar", "dar de comer aos bichos" dizem "entrego você", "aprendi brigar", "dar de comer os bichos". É só uma vogal, um $a$, a ausência de um $a$. Mas a cada vez que 'esbarramos' com essa ausência, ela faz um ruído, se faz notar, e parece exigir do ouvinte-tradutor uma decisão quanto a preencher a lacuna ou deixa-la lá, visível na sua invisibilidade, audível na sua mudez.

E de ruído em ruído, de deslocamento em deslocamento, de discretas ou não tão discretas inversões, sentimos como que um afrouxamento saudável de articulações enrijecidas da língua, e com isso, quem sabe, o estremecimento de todo um modo de viver e de pensar.

À tarefa de tradução sobrepôs-se, na criação do texto, a tarefa de montagem. Aqui, como no filme, em termos objetivos, a montagem consiste, em primeiro lugar, em cortar, reduzir, excluir, retirar tudo o que não é, a fim de fazer ver o que é, aquilo que já está lá, mas, paradoxalmente, precisa ser criado. Depois de reduzir, o que se fará é criar uma ordem, uma estrutura em torno da qual serão articuladas as unidades mínimas - os planos, no caso do filme, e as palavras, no caso do texto.

$\mathrm{Na}$ ausência de um enredo ou de qualquer fio condutor, o 'texto' foi estruturado como um conjunto de monólogos e diálogos que se organizam em torno de determinadas afinidades ou temas: estórias de amor, de assombração, de capeta, etc. Os monólogos são, na realidade, partes de um diálogo indicado não apenas pela presença dos travessões, mas também pelas alusões diretas ou perguntas que os falantes dirigem ao interlocutor - Olha, eu vou dizer uma coisa pra você. Não é assim que se diz? - e ainda pelas falas que trazem a pergunta embutida: O Morro? Eu subia lá era todo domingo.

Não há narrador (exceto pelas três últimas linhas do 'texto', extraídas do conto, que trazem, pela primeira e única vez, a perspectiva de um). Os falantes não são nomeados, caracterizados ou descritos. Deles só sabemos o que se revela através de suas falas. Sempre em primeira pessoa, essas falas são, frequentemente, entremeadas por falas alheias. Os falantes encenam e contracenam com os personagens de suas histórias fazendo duplo papel: - Eu tava saindo de casa quando apareceu um sujeito lá: - Ô Tunico, o mundo vai acabar, Tunico. Não adianta a gente trabalhar, nós vamos morrer de fome, de sede, assado, cozido, torrado no sol!” Eu falei: “E um tição de fogo na bunda, também! Até chorar ele chorou. E 
eu rindo dele. Deixa de ser bobo caboclinho." No registro audiovisual, essa encenação envolve, muitas vezes, uma mudança de voz, de timbre, para cada personagem que toma parte no diálogo.

Além desses diálogos, interpolados nos monólogos, há momentos no 'texto' em que a diversidade de opiniões e pontos de vista indica uma multiplicidade de falantes. Esses diálogos - na verdade, 'polílogos' - são produto do trabalho de edição, já que as entrevistas foram sempre individuais. Além disso, as vozes falantes, são, muitas vezes, a reunião das vozes de vários falantes. Esse recurso, normalmente indisponível na montagem cinematográfica, foi utilizado de forma recorrente no experimento de escrita.

A experiência desse 'texto' com sua estratégia de criação permite-nos pensar na autoria não como expressão da interioridade de um sujeito - estável, único, determinado - mas como um agenciamento de vozes e saberes coletivos. O autor, que "não para de desaparecer", é, aqui, menos aquele que fala do que aquele que escuta. Aquele, através de quem, um outro fala: um recadeiro. 


\section{ATO DE LEITURA}

Ver é uma fábula.

Paulo Leminski

Em “Le sacré dans la vie quotidienne', Michel Leiris fala de uma espécie de vertigem que se produz quando descobrimos a pronúncia correta de uma palavra que durante muito tempo pronunciamos de forma errada, ou da perturbação provocada quando duas variações de uma mesma palavra são colocadas lado a lado, através de retificações, na fala ou na leitura. Segundo Leiris, nessa mínima brecha que se abre entre as duas variações podemos "entrever inesperadas perspectivas e um mundo de revelações". ${ }^{41}$ Essas palavras ou expressões mal entendidas ou mal lidas, ricas em reverberações, por sua sonoridade mesma, ou pelo contexto em que se inserem, desviaram o interesse do autor, em seus estudos sobre o sagrado, "do terreno sólido dos fatos para as areias movediças dos fatos de linguagem”. ${ }^{42}$

Acreditamos que, tanto a escrita super elaborada de Guimarães Rosa, quanto a escrita extraída da fala dos moradores de Morro da Garça, estão repletas de "fatos de linguagem" capazes de provocar, cada uma a seu modo, vertigem e perturbação semelhantes àquelas descritas pelo autor.

O que se pretende realizar, neste segmento do trabalho, é um ato de leitura do texto "Tudo significa, as coisas". Assim chamada, a leitura apresenta-se antes como ação, gesto, performance, do que como exercício de decifração ou interpretação. O olho que lê - o experimento de escrita - é um olho que cria, pelo menos parcialmente, aquilo que lê, e isso não deve ser atribuído ao fato de que, aqui, o "agenciador da escrita" e o realizador do ato de leitura são a mesma pessoa.

Tomemos a frase que dá título ao trabalho: Tudo significa, as coisas. A primeira parte - Tudo significa - pode ser lida, talvez, como um enunciado sobre o sentido, e gostaríamos de pensá-la, aqui, em contraposição à formulação Tudo tem um significado, que seria a mais usual. Enquanto Tudo tem um significado soa como

\footnotetext{
${ }^{41}$ LEIRIS. 1995, p.100 (tradução minha). Originalmente uma conferência no Collège de Sociologie

42 LEIRIS, 1995, p115
} 
se houvesse um significado preexistente, já-dado, a forma Tudo significa parece querer dizer: 'tudo fala' ("como quando tudo era falante, no inteiro dos camposgerais...") ${ }^{43}$ Mas, se 'tudo fala', então, tudo é sujeito? Acaso poderíamos ler Tudo significa como "todos os existentes são centros potenciais de intencionalidade"? ${ }^{44}$ Aqui, como de resto, em todo o trabalho, as perguntas são exercícios especulativos para as quais, obviamente, não temos respostas.

Ao rejeitar a forma que seria a mais habitual, o que se estaria rejeitando, então, seria a ideia, que atravessa a história da metafísica ocidental, de um significado transcendental - original ou último - a ser descortinado. E, na ausência de significado transcendental, o campo e o jogo da significação ampliam-se, indefinidamente. Indo ainda mais longe, poderíamos nos arriscar a pensar que, na formulação de Washington, essa ampliação do campo da significação (dada a ausência de significado transcendental), se efetua pela via da proliferação dos signos, num processo que talvez possa ser referido como uma espécie de 'semiotização' do mundo. Tudo significa também poderia ser lido como "tudo é signo":

\begin{abstract}
Nesse movimento pelo qual a linguagem abandona a sua função comunicativa, para tornar-se valor e palavra pensante, ela passa a coincidir com o próprio Ser. Dentro deste universo tudo é signo e mesmo as coisas do mundo material assumem o perfil do discurso; tudo é susceptível de leitura, mesmo que seja o "rápido nhar de um gavião, passando destombado, seu sol nas asas chumbo". (PRADO JR, 1985: 224 )
\end{abstract}

Em Tudo significa podemos ouvir também: nada é insignificante, ou seja, tudo é sagrado. Mas um mundo em que tudo, de fato, significasse, seria, provavelmente, um mundo insuportável, assim como um mundo em que tudo soasse, sem silêncio.

Depois de Tudo significa, contrariando a expectativa natural de transitividade, há uma pausa, que se traduz por vírgula, seguida de as coisas. $\mathrm{Na}$

\footnotetext{
43 RM:101

${ }^{44}$ VIVEIROS DE CASTRO.2015,p.42
} 
sintaxe corrompida da frase, o complemento não complementa - continua faltando um objeto para o verbo - e ao mesmo tempo, transborda.

$\mathrm{Na}$ continuação da entrevista, podemos acompanhar a máquina de significação de Washington operando de diferentes modos. Num primeiro momento, ele diz: Essa cabaça aqui significa garrafa de água dos trabalhadores, que eles levavam pra roça. Aqui, a significação é dada pela função do objeto, sua utilidade. Mais adiante, ele afirma: Esse aqui é um fogãozinho de lenha significando as coisinhas simples da roça. Agora, a relação que se estabelece é de continuidade, do tipo metonímica. E, por fim: E esse aqui é um bulezinho de café significando...um jardim. Neste caso, o significado se descola, definitivamente, de seu objeto de referência, e a liberdade com que Washington realiza a operação surpreende o ouvinte. Que um bule signifique um jardim, a rigor, não é uma operação mais arbitrária do que aquela que faz com que um bule signifique um bule, mas a estranheza da formulação "escancha os planos da lógica" e revela, pelo avesso, os limites do senso comum."E o não-senso, crê-se, reflete por um triz a coerência do mistério geral, que nos envolve e cria. A vida também é para ser lida. Não literalmente, mas em seu supra-senso."

“Lá - estava o Morro da Garça: solitário, escaleno e escuro, feito uma pirâmide."

Nessa passagem do conto, o morro é apresentado como algo, no mínimo, ambíguo. Ele é coisa bruta, natural, pré-humana e, ao mesmo tempo, escaleno, é coisa mental, geometria, abstração. "Feito uma pirâmide", é como se o morro fosse também obra de arquitetura, produto tanto da inteligência quanto do trabalho braçal. Além disso, a pirâmide é lugar de passagem entre o mundo dos vivos e o dos mortos, e o morro, sabemos, fala. Em apenas uma linha, portanto, os limites entre humano e não humano, natural e artificial, material e transcendental se tocam e se deslocam, sutilmente. Esse deslizamento permanente de fronteiras, uma espécie de contaminação recíproca entre os mundos, perpassa todo o conto, e pode ser

\footnotetext{
${ }^{45}$ ROSA. 1985, p.08
} 
observado também em diferentes momentos do experimento de escrita como se fosse peça fundamental do 'sistema operacional' do homem do sertão.

Eu vou falar de tudo que meu Pai criou: das mulheres, da memória, da cabeça, do coração, do rancho, do prédio. Das ruas, das estradas, do asfalto, da terra, dos passarim... Eu vou falar de coisa que homem nenhum falou ainda. Das cascas da madeira, os desenhos dos paus, os frisos, entendeu? A música, a formiga, o cupim, o carrapato, essas coisas. Das pedras. Da humildade, da simplicidade, do respeito, da verdade, da sinceridade, dessas maravilhas. Do amor, da fidelidade, de tudo! Do anzol, do bambu, tudo! Eu vou falar de tudo que meu Pai criou, o Senhor.

O heterogêneo conjunto das coisas que Washington vai cantar abarca não apenas coisas construídas (o rancho, o prédio, as estradas) e coisas não-construídas (as mulheres, os passarinhos, o bambu), como também coisas elevadas (o respeito, a verdade, a sinceridade) e coisas desprezíveis (o cupim, o carrapato); coisas concretas (o asfalto, a terra, as pedras) e coisas abstratas (a memória, a simplicidade, o amor).

A definição daquilo que pertence ao mundo do 'construído' e daquilo que pertence ao mundo do 'dado’ é, ela mesma, uma construção, e não uma construção qualquer, mas uma construção por meio da qual as culturas se distinguem. Se entendermos "tudo que o Senhor criou" como tudo aquilo que é dado, isto é, nãoconstruído, veremos que, na fala de Washington, a oposição entre natureza e cultura - a base sobre a qual se assentam muitas outras oposições - se revela estremecida. Essa oposição, digamos, fundamental - desde sempre problemática e problematizada para e pela antropologia - permanece sendo uma questão da qual nem a ciência nem o senso comum conseguem escapar. Em seu esforço para colocar ordem no mundo - nomeando, enumerando, agrupando - Washington acaba por revelar a desordem e a multiplicidade do mundo.

Em outro momento, o mesmo personagem diz: Tá vendo essa pedra aqui? Tá vendo o estilo dessa pedra? Numa busca rápida ao dicionário, a palavra estilo é definida como "o conjunto das qualidades características de uma obra, um autor, uma época" Embora possa ser utilizada para se referir a 'coisas dadas' - pode-se dizer de um gato ou de um cavalo que eles têm estilo - a aplicação mais comum e, 
talvez, a mais 'apropriada', é para falar de 'coisas construídas'. Mas graças ao uso 'inapropriado' da palavra somos levados a pensar que, dona de um estilo, é como se a pedra partilhasse, de certa forma, do estatuto de coisa construída. Mais adiante, ele afirma: - Essa pedra é criação de Deus. Porque Deus é que cria as pedras também. Se Deus criou as pedras também é porque além ou antes delas, já havia criado outras coisas. As plantas, as águas, os animais? Esse também parece apontar para uma posição como que secundária das pedras dentro do conjunto das coisas dadas. Estariam as pedras mais próximas das coisas construídas? No mesmo parágrafo, ele prossegue: - E o Senhor falou: Se o homem não falar, as pedras vão falar. Já imaginou!? Você passando perto de uma pedra e a pedra falando pra você: - Leia a Bíblia! Jesus tá voltando! Jesus reina! Heim!? Hã!? Aí nego ia até correr, né? Ver uma pedra falando! Nesse momento, é como se o potencial de fala da pedra, cuja estranheza não escapa à consciência de Washington, dotasse o mineral de certa humanidade. No discurso de Washington, então, é como se a pedra participasse, em alguma medida, simultaneamente, do reino das coisas dadas e do reino das coisas construídas, do reino mineral e do reino humano. É interessante observar que, assim como o personagem Gorgulho, que tem consciência da ironia de que é objeto por parte dos viajantes letrados, Washington também mantém uma espécie de distanciamento crítico diante do fato inusitado, ou seja, em ambos, a admissão do sobrenatural não exclui por completo a perspectiva racionalista.

$\mathrm{Na}$ 'cosmogonia' do sertão, coisas, plantas, humanos e animais são partes de um todo integral e a relação que estabelecem entre si é antes de fraternidade e co-pertencimento que de dominação e subordinação. Enquanto Pê-Boi, personagem do conto, pensa na "vaqueirama irmã", Seu Tonico se refere à pata do cavalo como mão, à crina como cabelo, e ao animal domesticado como um menino manso. Mas se os animais se mostram, assim, antropomorfizados, os humanos são também, por outro lado, animalizados, como se vê nessa inspirada formulação: Foi eu mais ela os dois primeiros que correram a mão no pelo um do outro. Em outro momento, observa-se a união, até quase a fusão, entre o homem e o cavalo: - Se eu não tô aqui é porque eu tô nele. Nós dois não separa, não. Nós dois é um só. Assim, “os bichos e as plantas não são apenas naturais, mas seres pervasivos que a nós aderem e que em nós se instalam." ${ }^{, 46}$ 
E você tá na estrada tocando gado, o gado vê o cachorro empareado com a gente, eles respeitam a mesma coisa que fosse um homem. Eles respeitam o cachorro. Igual se tem um perigo lá pra diante, o cachorro vai e conta logo como é que tá o negócio, o negócio lá tem perigo. E logo o gado também vê aquilo (o perigo) e aquieta todo mundo. E agora ele anda em volta e vem até pra junto da gente também como se tivesse dizendo: me acode. Anda e chega lá perto de nós, como dizendo: tamo aqui. O gado também é a mesma coisa que nós.

Não é de se estranhar que muitos dos “fatos de linguagem” observáveis no experimento de escrita encontrem ressonâncias, equivalências ou semelhanças em "O recado do morro", bem como no conjunto da obra de Guimarães Rosa. Afinal, essas escritas se alimentam, cada uma a seu tempo e a seu modo, da mesma "língua brasileira do sertão". Ao aproximar essas duas escritas, o que se pretende, portanto, não é comprovar o já suficientemente comprovado caráter documental da obra de Rosa. Ao atualizar, mais de 60 anos depois, em condições de possibilidades infinitamente distintas, os procedimentos utilizados pelo autor, o que se revela - ao vivo e em cores - é que aquele metal continua lá, escondido sob a mesma "montanha de cinzas." ${ }^{47}$ E se a relação que estabelecemos com Rosa é, por assim dizer, de aprendiz e mestre, diante do "povo inventalíngua", somos ambos aprendizes. Nunca é demais lembrar, entretanto, que na escrita de Rosa, o popular aparece conjugado, de modo personalíssimo, ao erudito e ao arcaico, e que a figura, quase folclórica, do escritor viajante 'esconde' um intelectual poliglota e sofisticado inventor de estilo artificioso e difícil.

A presença dos diminutivos, que Guimarães Rosa incorpora habilmente a sua escrita, é um desses "fatos de linguagem" que saltam aos olhos - ou aos ouvidos - na fala dos entrevistados. Se, em "Campo Geral", a estória de Miguilim, que também está em Corpo de Baile, a recorrência dos diminutivos pode ser vista como uma forma de expressar a escala de visão do protagonista míope, como assinala Ana Luiza Martins Costa, ${ }^{48}$ em "O recado do morro" - e aqui é a audição e não a

\footnotetext{
46 NUNES, 279

${ }^{47}$ ROSA, entrevista a Gunter Lorenz

48 MARTINS COSTA, 2011
} 
visão que está em jogo - a presença dos diminutivos continua a chamar a atenção: aguinha, ponderadinho, cisminha, demoninhos, superlim, passarim, regularzim, riachim, razoavelzim, lagoazinha, vêiazinha, furozinho... Em carta para o tradutor italiano Edoardo Bizzarri vemos:

“8[26]: “superlim” ( no alto da gameleira?)

Sim, vigora, também, a conotação: SUPER. Mas:

superlim $=($ super-lindo? $)$ muito gentil, encantador.

(Valeu, no texto, pela rima, ritmo, aliteração. E

pelo agudo, insistido, da vogal i.)

As mesmas variações - formadas pelos sufixos -inho, -im, -zinho - aparecem no experimento de escrita, onde observa-se, ainda, o caso em que o sufixo -zinho é somado à terminação -inho numa espécie de duplicação do grau diminutivo: assombradinhozinho, doidinhozinho, senhorinhazinha. O comentário de Eduardo Coutinho a respeito da criação da forma sozinhozinho, em "Grande sertão: veredas", colabora para a reflexão:

A palavra "só", basicamente referencial em português, não contém em si mesma nenhuma conotação emocional. $\mathrm{O}$ poeta anônimo, ao sentir certa vez que o vocábulo era insuficiente para expressar sua solidão, decidiu, então, acrescentar-lhe um sufixo diminutivo -inho, -zinho, bastante usado na língua com o sentido de intensidade (cf. "cedinho", "devagarzinho"). E o resultado foi a palavra "sozinho", significando "muito só". Não obstante, com o desenvolvimento da língua, "sozinho" veio a perder seu significado poético e passou a ser usado como um simples sinônimo de "só". Guimarães Rosa, percebendo a inexpressividade do vocábulo, procurou reavivar seu significado originário, servindo-se do mesmo processo que acreditava tivessse sido utilizado um dia. Assim, repetiu o sufixo diminutivo no final e criou a forma "sozinhozinho". (COUTINHO, 1995:15)

A presença de formas aumentativas, tanto no conto como no 'texto', também chama a atenção e seu uso parece servir menos como indicador de tamanho 
do que como uma maneira de produzir realce. Em "O recado do morro" encontramos o uso inusitado do sufixo -ão acoplado a uma forma verbal "exclamouzão" - e a um adverbio - "quandão" - além da estranha ocorrência "falanfão". Essa liberdade de alterar a afixação e fazer novas derivações das palavras, tão ao gosto de Rosa, também pode ser encontrada no 'texto' em graciosos exemplos como desascismou e namorista.

No lugar das metáforas náuticas de que nos fala Walnice Nogueira Galvão ${ }^{49}$ a proposito do conto "Desenredo", do livro Tutaméia, encontramos no experimento de escrita, com uma frequência não desprezível, a presença de termos aeronáuticos como aterrissar, pousar e navegar - este último, usado nos dois meios. As limitações desta pesquisa não permitem que se extraiam as consequências devidas de muitos dos fatos observados. Essas observações devem ser entendidas, portanto, como apontamentos para um possível trabalho a ser futuramente desenvolvido.

Os versos, quadras e improvisos que estão espalhados nas cadernetas e nas obras de Rosa, ao lado de provérbios, ditados, e expressões populares também ocupam lugar no 'texto', assim como os enunciados formulares, em tom sentencioso como: Se a felicidade fosse direto, ninguém acreditava que tinha o capeta! ou Menino sem mãe é só de sofrer. No longo improviso, composto de 29 versos, recuperado e recitado por Seu Nonato, um dos entrevistados do filme, verificamos que a composição obedece a um rígido padrão métrico que alterna versos de seis e de cinco sílabas.

Chama a atenção, ainda, a frequência com que a expressão "o povo fala" e suas variações como "eles falam”, "dizem”, "o pessoal anda dizendo" - aparece. É como se o falante quisesse, de certa forma, dividir com o outro a responsabilidade sobre o que é falado. Mas a expressão também parece inserir a fala numa rede de falas, como se o falante estivesse sempre redizendo o que um outro já disse. Como se cada um deles fosse um recadeiro, a estação de transmissão de uma mensagem que circula pelo ar.

49 GALVÃO.1996 
Além da faculdade intelectiva, a escrita de Guimarães Rosa dirige-se, frequentemente, aos sentidos do leitor: tato, olfato, visão, audição e até o paladar não raro são convocados na leitura. As cadernetas estão cheias de anotações sobre as cores, os cheiros, as formas e os sons das coisas, e esses elementos irrompem nas narrativas, a todo momento:

\begin{abstract}
"Pelas abas das serras, quantidades de cavernas — do teto de umas poreja, solta do tempo, a aguinha estilando salôbra, minando sem-fim num gotêjo, que vira pedra no ar, se endurece e dependura, por toda a vida, que nem renda de torrõezinhos de amêndoa ou fios de estadal, de cera-benta, cera santa, e grossas lágrimas de espermacete; enquanto do chão sobem outras, como crescidos dentes, como que aquelas sejam goelas da terra, com boca para morder. Criptas onde o ar tem corpo de idade e a água forma pele muito fria, e a escuridão se pega como uma coisa. $\mathrm{Ou}$ lapinhas cheias de morcegos, que juntos chiam, guincham, porfiam." (ROSA, 2001:29)
\end{abstract}

A excepcional sensibilidade acústica do escritor - entre tantas outras excepcionais qualidades - é responsável pela disseminação, em toda a obra, de ruídos, barulhos, chiados que não encontram tradução em palavras de dicionário. Além das interjeições, expletivos e onomatopeias reconhecidas pela gramática, podemos perscrutar, em diferentes obras, uma profusão de palavras que são apenas sons, desprovidos de significados identificáveis.

Numa paisagem em que tudo soa - cada bicho, cada pássaro, o vento, a água, a mata, o carro de boi - a voz humana perde a soberania absoluta e, com isso, o som, normalmente subordinado ao sentido, ganha supremacia, subvertendo o hábito de considerar a palavra apenas como instrumento para a transmissão de significados.

Como uma música, então, a língua de Rosa nos chega por outros canais, antes sensoriais do que cerebrais. Mas a dimensão de música de sua escrita não se efetua apenas através da presença desses sons brutos, semi articulados, desorganizados. Na linguagem de Rosa, a dimensão material da palavra - ritmo, sonoridade, intensidade - jamais é tratada como secundária. Nas já citadas correspondências com seu tradutor italiano Edoardo Bizzarri, são inúmeras as vezes em que a explicação ou justificativa para o uso de uma palavra está na sonoridade, 
na rima, no ritmo, na aliteração, na "expressiva carga de estranheza e mistério", no aspecto, na "beleza física da palavra".

Em "O recado do morro", a presença desse som sem sentido se faz notar não só nas interjeições e expletivos mais comuns como Ah, Eh, Ê, Ô, Ó, Ho, e em regionalismos como Uai, Uê, Arre, Ara, mas também em formas mais inusitadas como "brumbrum", "nhã-ã", "nhum". No experimento de escrita, as mesmas interjeições monossilábicas - Ah, Ô, Ó, Ê - e regionalismos como sô, vixi, ixi, pontuam toda a fala, do início ao fim. Estão lá também as onomatopeias de uso consagrado - Poc, poc, poc, ou tchap, tchap, tchap - as imitações acústicas dos sons escutados - cró-cró-cró e peeexx-fritu - e outros sons soltos, inarticulados, não 'domesticados'. Nesses momentos, em que o conteúdo da palavra "submerge no mar universal do som", ${ }^{50}$ resta-nos, e isto não é pouco, a pura "intensidade sensitiva", a "originária melodia da linguagem".

Essa língua que beira a inarticulação, que transborda da palavra para a nãopalavra, pode ser observada, no filme e no 'texto', em dois momentos em que vozes vindas de outro mundo estremecem o terreno seguro da enunciação. O primeiro deles é a reprodução de uma conversa com um doido que diz estar vendo o capeta:

Uma vez, tinha um tal de Dete, doidozinho da cabeça. Ai esse cara ficava: - "Vixe! Vixe!" - O que que é, Dete? - "O capeta!” Eu falei: - Dete, Dete, que capeta é esse, Dete? "Olha aí, ó! Olha aí, ó!" Aí eu falei: - Eu não tô vendo nada, não. É você que tá com esse capeta. - "Nooossa Senhora! Noooossa Senhora!" - O que que é, Dete? - "Ó, o fogo! Ó, o fogo! A sua cabeça tá acabando de cortar o pescoço fora! Piii-piii-piii-piii-piii!"

E o segundo, a descrição de uma aparição da "luz":

Ah! Ai quando ele vinha de lá aqui pro Morrão, essa luz montou em cima do rabo do carro dele, ela pousou no carro dele, e evéeem, e evéeem, e evéemm, immmm, immmm...

\footnotetext{
${ }^{50}$ NIETZSCHE, 2007
} 
Nos dois casos, a ininteligibilidade da fala fez com que esses trechos fossem descartados, por um longo período, durante o processo da edição. Mas o motivo pelo qual eles foram descartados foi o mesmo que fez com que eles fossem resgatados e inseridos no filme. Passamos da rejeição à compreensão de que ali, justamente na impossibilidade de dizer, no esgarçamento da palavra até o limite da sua dissolução em puro som, ao contrário do que havíamos suposto, estava a própria potência da linguagem revelada, paradoxalmente, em sua impotência. 
3

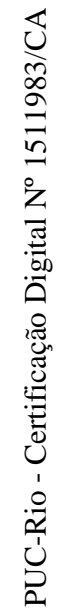


NOTAS RELACIONAIS 


\section{O TEXTO}

Existe Deus, também.

Existe. Existe o céu, existe Deus morando lá, existe o capeta, também, existe o inferno, também. Não precisa ninguém duvidar, não, que tem de tudo, tem.

\section{AS CADERNETAS}

O CONTO 
(para ele, Guimarães

Rosa)..o único problema

fundamental do homem

era saber se Deus existe

ou não. $\mathrm{O}$ mundo de

Guimarães Rosa não é

Minas. O mundo de

Guimarães Rosa é o

mundo. Porque dentro

daquele enquadramento

rigoroso, documentário

do sertão mineiro,

aquilo serviu de palco

para ele desenvolver um

drama que ocorre em

qualquer lugar do

mundo. Ocorre em

Dostoievski, ocorre em

Proust, ocorre em

Stendhal, ocorre em

Joyce. Os problemas do

homem. Quem sou eu?

Quem é você? Deus

existe? Deus não existe?

O que é o bem? O que é

o mal? O culpado é ele

ou sou eu?

(Antônio Cândido) 


\section{O TEXTO}

Gerais é aí, ó, nesse

mundo aí. Aí nesse lugar

onde nós tava. Aí pra

baixo era Gerais mesmo.

Só tinha era vereda, era

campina, era só

gorgulho de pedra e

capim barba-de-bode...

Esse trem era o Gerais.

Cerradinho baixo, raso.

É o Geraisão. Areia.

\section{AS CADERNETAS}

O CONTO

1. Zune o vento, em meu chapéu.

Tapiocanga

em

pedrinhas, entre os

capins oscilantes

(acenantes)

( Qualquer pedrinha assim deste formato e tamanho, chamam "gorgulho").

(p.147)

2. - A tapiocanga é uma pedra cangicuda. Esta aqui eles chamam de "pedra preta"...

(p.150) 
NOTAS AVULSAS

02.01.2013

Uma completamente

outra sensação do

tempo. Outro

andamento. Mesmo

com as gravações,

que ocupam boa parte

dos dias, o tempo

sobra, passa devagar.

O calor seco causa

uma espécie de

torpor. Mas não é

amolecedor, como o

do Rio. A sola do pé

permanentemente

vermelha.

\section{OUTROS}

O FILME

(...) pois "gorgulho", palavra ligada ao mundo do garimpo e da mineração, é o pedregulho do leito do rio que esconde valor, 'fragmentos de rocha entre os quais se encontra ouro'. (José Miguel Wisnik) 


\section{O TEXTO}

Aí eles chegaram com a boiada e pousaram lá nessa fazenda onde nós tava, lá, no Gerais, lá, no

\section{Catatau (...)}

Aí eu perguntei onde é que eles iam passar: - $\mathrm{Na}$ Serra das Cabras nós sobe; na Serra do Cruzeiro nós vamos descer; nós vamos pousar lá pro lado do Riacho das Vacas e vamos descer por aí abaixo, vamos caçar Bicudo por aí abaixo. E esse povo andando, na lida...

\section{AS CADERNETAS}

1. Roteiro da boiada (Manoelzão): $1^{\circ}$. Tolda ( segunda, 19 ) $2^{\circ}$. Andrequicé ( terça, 20 ) $3^{\circ}$. Santa Catarina ( quarta, 21$) 4^{\circ}$. Catatau ( quinta, 22 ) $5^{\text {a }}$. Riacho Das Vacas ( sexta, 23 ) $6^{\circ}$. Sítio ( sábado, 24 ) $7^{\circ}$. Retiro dos Bravos ( domingo, 25) $8^{\circ}$. Brejinho ( Taboquinha) - (segunda, 26) $9^{\circ}$. Juvenal ( terça, 27 ) $10^{\circ}$. Cordisburgo ( quarta, 28) $11^{\circ}$. Fazenda São Francisco ( quinta, 29) (p. 98)

2. No Riacho da Vacas ( continuação da página anterior) :É uma represa natural. Escorregoso, onde a água desliza sobre as lages azuladas. (p. 150)

3. O Rio Bicudo. Barragem e parí. (5hs menos 15)

Rio do Carmo ( afluente do Bicudo) (p.33) 
NOTAS AVULSAS

OUTROS

O FILME

29.12.2013

As vacas não ficam

indiferentes à nossa

presença. Elas são

pacatas mas parecem

bravas. A vaca que

'uiva'. Um grito, um

lamento, um mugido

que eu nunca ouvi

igual. E não consigo deixar de pensar que

aquele lamento era

endereçado a nós,

atrás da cerca, com as

câmeras. 
O TEXTO

\section{AS CADERNETAS}

3. (Dona Benedita, viúva do Octavio. Sr.

Agenor. Diva, Santinha

e Luisa. Carnelygia, a pequena charadista.

Dalberto.) (p.143)

\section{O CONTO}


NOTAS AVULSA OUTROS

\section{O FILME}

Aí no outro dia ele falou:

- Ó, Carnelygia, você, mais a Diva, nós tamo indo embora, mas tamo levando aqui essa escrita, o nome desse povo todo aqui,! Tá tudo escrito aqui pra mó de fazer um livro! Do lugar onde nós andamos. 
O TEXTO

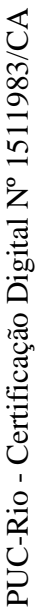

\section{AS CADERNETAS}

- Como é que se pode

conhecer esses

espigões? É tudo

igual... (Sempre uma

estradinha descendo...) é

mesmo que campear em

lugar de vargem...

(p. 177)

\section{O CONTO}

- Como é que um pode

conhecer esses espigões? É tudo igual, é tudo igual...É o mesmo difícil que se campear em lugares de vargem...

(p.64) 
NOTAS AVULSAS

12.01.2013

Não. "O recado do

morro" não era, nem de

longe, minha estória

preferida do autor.

Hermética, nebulosa,

emaranhada, da primeira

leitura posso dizer que

foi, no mínimo,

'desconfortosa'.
O FILME

OUTROS 
Ah, morena!

Eu vi o mutum gemer, oi-iá

Eu vi o mutum gemer

Ah, morena!

Meu corpo todo tremer, ai, ah! $\begin{array}{ll} & \\ \text { O TEXTO } & \text { AS CADERNETAS } \\ \text { Em cima daquele morro } & \text { Mutum }- \text { no meio do }\end{array}$

$\begin{array}{ll} & \\ \text { O TEXTO } & \text { AS CADERNETAS } \\ \text { Em cima daquele morro } & \text { Mutum }- \text { no meio do }\end{array}$ mato, de madrugada, ele hum...

(p. 47) hum... $\begin{array}{ll} & \\ \text { O TEXTO } & \text { AS CADERNETAS } \\ \text { Em cima daquele morro } & \text { Mutum }- \text { no meio do }\end{array}$

$\begin{array}{ll} & \\ \text { O TEXTO } & \text { AS CADERNETAS } \\ \text { Em cima daquele morro } & \text { Mutum }- \text { no meio do }\end{array}$

geme: - Hu-hum...Uhu-

\section{O CONTO}

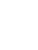

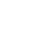


NOTAS AVULSAS
OUTROS

O FILME

1. MUTUM: ave

galliforme da

família Cracidae. O nome popular mutum se origina da palavra "mitú", da língua tupi, e vem da onomatopeia de seus chilros, alaridos e chamados. (Wiki Aves)

2. Um certo Miguilim morava com sua mãe, seu pai e seus irmãos, longe, longe daqui, muito depois da Vereda-doFrango-d'Água e de outras veredas sem nome ou pouco conhecidas, em ponto remoto, no Mutúm.

("Campo Geral”, J.G. Rosa)

3. (...) "mutum", em latim mutus (-a, -um), significa "mudo, silencioso", ou remete aos animais que só sabem "mu gir" ou "dizer mu" (...)

(Ana Luiza Martins Costa) 


\section{O TEXTO}

O Morro? O Morro eu

subia lá era todo

domingo. Eu gostava de

caçar. Tinha muito tatu,

tinha paca, lontra,

veado, catingueiro,

capivara, raposão...

Tinha muita coisa lá.

Tamanduá. Suçuarana.

Mas suçuarana não faz

mal a ninguém, não. Ela

num guenta um grito! Se

você gritar, ela corre. encara, não.

\section{AS CADERNETAS}

1.Sempre, à esquerda, o

Morro da Garça -

pirâmide rasa. Corcova

de camêlo, às vêzes. Às

vezes, uma tartaruga.

Escuro.

(p.147)

2.Môrro da Garça:

daqui parece um bisão (

bisonte ) a emergir.

(p. 147)

3.Estamos nos altos da Trindade. Avista-se, atrás, a igrejinha do São Tomé. Ao longe, pequenino, mamelar, o Môrro da Garça!

(p. 185)

\section{O CONTO}

(...) que, por dias e dias, caceteava enxergar aquele Morro: que sempre dava ar de estar num mesmo lugar, sem se aluir, parecia que a viagem não progredia de render, a presença igual do Morro era o que mais cansava.

(p.51) 
NOTAS AVULSAS

23.12.2012

O Morro é visível de qualquer lugar. De onde quer que você olhe, ele está lá: solitário, escaleno e escuro, feito uma pirâmide.
OUTROS

O FILME

O Morro da Garça

constitui uma estrutura de morfologia circular com 1,6 km de diâmetro, realçada cerca de $350 \mathrm{~m}$ acima de uma região extremamente plana no centro-norte de Minas Gerais. Tal feição ressaltada na paisagem tem servido ao longo dos últimos séculos como um guia de referência para tropas e viajantes e, ao seu sopé desenvolveu-se a cidade de Morro da Garça. (revisata Geonomos) 


\section{O TEXTO}

Tá vendo essa pedra aqui? Tá vendo o estilo dessa pedra? Ela é toda quebradinha, assim, parecendo uma piramidezinha... Aí, com a minha visão, eu falei assim: - Essa pedra tá aqui, ninguém viu essa pedra, não!? No meio da rua, rapaz! A pedra no meio da rua. Esse povo daqui não tem criação, não? Quê isso, sô! Aí eu trusse ela e coloquei aí. Essa pedra é criação de Deus - porque Deus é que cria as pedras também. E o Senhor falou: (...) Se o homem não falar, as pedras vão falar. Já imaginou!? Você passando perto de uma pedra e a pedra falando procê: - Leia a Bíblia! Jesus tá voltando! Jesus reina! Heim!? Hã!? Aí nego ia até correr, né? Ver uma pedra falando!

\section{AS CADERNETAS}

O CONTO

... E um morro, que tinha, gritou, entonces, com ele, agora não sabe se foi mesmo p'ra ele ouvir, se foi pra alguns dos outros.

(p.59)

\section{Á,}

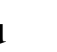

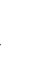
(n) 
NOTAS AVULSAS

13.08.2014

"No meio do caminho

tinha uma pedra

tinha uma pedra no meio

do

caminho"
OUTROS

O FILME

Pense-se, por exemplo,

no conto $A$

alexandrita, que coloca

o leitor nos velhos

tempos em que "as

pedras nas entranhas da

terra e os planetas nas

esferas celestes se

preocupavam ainda com

o destino do homem, ao

contrário dos dias de

hoje, em que tanto no

céu como na terra tudo

se tornou indiferente à

sorte dos seres

humanos, e em que

nenhuma voz, venha de

onde vier, lhes dirige a

palavra ou thes

obedece. Os planetas

recém descobertos não

desempenham mais

nenhum papel no

horóscopo, e existem

inúmeras pedras novas,

todas medidas e pesadas

e com seu peso

específico e sua

densidade exatamente

calculados, mas elas

(cont.na página 16) 
O TEXTO

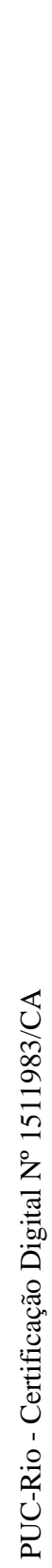

AS CADERNETAS

Serão

descarregamentos

subterrâneos, o desabar

profundo de camadas

calcáreas, como nos

terremotos de Bom-

Sucesso... Dizem que isso acontece mais é por volta da lua cheia...

(p.39) 
NOTAS AVULSAS
OUTROS

O FILME

não nos anunciam nada

e não têm nenhuma

utilidade para nós. $\mathrm{O}$

tempo já passou em que

elas conversavam com

os homens. (...)

2.Trata-se de uma pedra semipreciosa, o piropo.

A pedra é o estrato mais ínfimo da criatura. Mas para o narrador ela está imediatamente ligada ao estrato mais alto. Ele consegue

vislumbrar nessa pedra semipreciosa, o piropo, uma profecia natural do mundo mineral e inanimado dirigida ao mundo histórico, na qual ele próprio vive. (Walter Benjamin) 
O TEXTO


AS CADERNETAS

(...) o Gorgulho estava

recontando a doidice

aquela, de ter escutado

o Morro gritar? Pois

falava: $\ell$ Que que

disse? Del-rei, ô, demo!

Má-hora, esse Morro,

ásparo, só se é de

satanaz, ho! Pois-olhe-

que, vir gritar recado

assim, que ninguém não

pediu: é de tremer as

peles...

(p.48) 
NOTAS AVULSAS
OUTROS

A quem se comunica a

lâmpada? A quem, a

montanha? E a raposa?

- Aqui a resposta é: ao

homem. Não se trata de

antropomorfismo. A

verdade dessa resposta

se deixar ver no

conhecimento e, talvez

também, na arte. E

mais: se a lâmpada e a

montanha e a raposa

não se comunicassem

ao homem, como

poderia ele nomeá-las?

No entanto, ele as

nomeia; ele se

comunica ao nomeá-las.

A quem ele se

comunica?

(Walter Benjamin)
O FILME

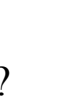

e




\section{O TEXTO}

Essa luz, quase todo mundo já viu ela. Mas ela não ofende ninguém, não. Ela sempre navega daquela morro, lá, até aquele outro pequenininho que tem ali. Ela sempre aparece. O povo fala, não sei, tem um tal de Juvenal, tatuzeiro, ele ia armar gaiola no meio do mato e pedia pra ela alumiá pra ele. E ela aparecia. Aparecia pra ele. Eu morava na Extrema, trabalhava de vaqueiro... Mais ou menos umas 2 ou 3 horas da manhã, veio a luz andando, no pasto, parecia uma luz de óleo. Andando. 
NOTAS AVULSAS
OUTROS

O FILME

É o feu-follet, a ronda dos Lutinos na França, Flandres; a Inlicht, a luzlouca da Alemanha, os pequeninos anões correm com archotes como os sul-americanos Yakãundys, (...); os fogos dos Druidas, o fogo de Helena, de Santa-Helena, antepassados do Sant'Elmo que os romanos identificavam com a presença divina de Castor e Pollux; (...)todas as terras vêem as luzes loucas, azuladas e velozes, assombrando. Em Portugal são as "alminhas", as "almas dos meninos pagãos", a "alma que deixou dinheiro enterrado" e não se "salvará" enquanto o ouro estiver escondido. É o "farol" dos Andes, Argentina e Uruguai, clarão que se escapa onde jaz um tesouro.

(Câmara Cascudo) 


\section{O TEXTO}

Existe ela que eu já vi.

Essa luz. Mas eu não

fiquei com medo, não. É

uma luz grandona e

branca, e ela fica

mudando de cor. Mãe

do ouro, luz andeja...

tem um monte de nome.

\section{AS CADERNETAS}

O CONTO 
NOTAS AVULSAS

OUTROS

O FILME

O que é hoje serra de

pedra já foi gente

vivente: foi gente num

tempo antigo, e por um

castigo do céu,

escureceu de repente e

caída ficou onde estava.

(...) Mas o que governa

tudo, que não se sabe o

que é, que é a Alma, que

não morreu, essa é que é

a Mãe do Ouro, porque

ela não entrou no

castigo, e que defende os

nervos dos castigados,

os veeiros da fortuna,

para que no dia do

Perdão cada um ache o

que seu é... Aí está

porque, quando troveja,

tantos raios caem sobre

certos serros e tanto

ventarrão esbarra

neles:... é a Mãe do

Ouro que chama

socorro...

(J.Simões Lopes Neto) 


\section{O TEXTO}

Porque o diabo tem

usado muito as pessoas

aqui nessa terra, já há 40

anos, e aí Deus tem dado

a eles o castigo. Porque

a ira de Deus fica por

cima da cabeça da gente.

Assim como ele dá as benção pra você, ele também permite que as coisa vem acontecer com você. As coisa ruim. Por causa que o

Deus que dá as coisa boa é o mesmo Deus que permite que as coisa ruim aconteça. É o mesmo Deus.
AS CADERNETAS

\section{O CONTO}

E o morro gritou foi que nem Satanás. Recado dele.

(p.59) 
NOTAS AVULSAS

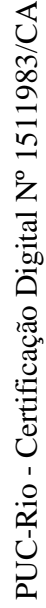

OUTROS

O Senhor não vê? O que

não é Deus, é estado do demônio. Deus existe mesmo quando não há. Mas o demônio não precisa existir para haver - a gente sabendo que ele não existe, aí é que ele toma conta de tudo.

(Grande sertão:

veredas. p. 49 )

\section{O FILME}




\section{O TEXTO}

- Eu não tenho medo de capeta, não, que ele não existe.

- Acho que, tipo assim:

Deus fez as coisas boas e o capeta fez as coisas ruins.

- Um dia desse, aqui, um sujeito veio de Curvelo, saiu lá do prontosocorro, veio, chegou aí, mandou o povo dele ir embora, pra dormir sozinho, aí quando o povo dele deu uma trégua - faca nele mesmo, não matou ele? Aquilo não tava com Deus, não. Aquilo tinha um capetinha junto com ele. 
NOTAS AVULSAS
OUTROS

E as idéias instruídas do

senhor me fornecem

paz. Principalmente a confirmação, que me deu, de que o Tal não existe; pois é não? $\mathrm{O}$ Arrenegado, o Cão, o Cramulhão, o Indivíduo, o Galhardo, o Pé-dePato, o Sujo, o Homem, o Tisnado, o Côxo, o Temba, o Azarape, o Coisa-Ruim, o Mafarro, o Pé-Preto, o Canho, o Duba-Dubá, o Rapaz, o Tristonho, o Não-seique-diga, O-que-nuncase-ri, o Sem - Gracejos... Pois, não existe! E se não existe, como é que se pode se contratar pacto com ele?

(Grande sertão: veredas. p. 67,68$)$

\section{O FILME}

\section{.}

.

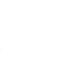




\section{O TEXTO}

- Pra mim existe. Existe

e não existe. Depende da

pessoa. Tem uma

história de um homem

que ficava fazendo

gracinha com o nome do

diabo, ali perto da praça,

aí o capeta pegou ele de

couro lá, num beco perto

da casa dele.

\section{AS CADERNETAS}

O CONTO 
NOTAS AVULSAS

OUTROS

O FILME

O diabo existe e não

existe? Dou o dito.

Abrenúncio. Essas

melancolias.

(Grande sertão:

veredas pág 32)

Do demo? Não gloso.

Senhor pergunte aos

moradores. Em falso

receio, desfalam no

nome dele - dizem só: o

Que-Diga. Vote! não...

Quem muito se evita, se

convive.

(Grande sertão:

veredas. p.30) 


\section{O TEXTO}

O quê que é isso, cavalo? Bobo! Você nunca viu o capeta, não? Aí esse cara ficava: Vixe! Vixe! Vixe! Aí eu falei: O quê que é, Dete? $\mathrm{O}$ capeta! $\mathrm{Eu}$ falei: Dete, Dete, que capeta é esse, Dete? Olha aí, ó. Olha ele aí. Não, não tô vendo nada, não. É você que tá com esse capeta. Nossa senhora, nossa

Olha o fogo. A sua cabeça tá acabando de cortar o pescoço fora....

senhora. Olha o fogo. 
NOTAS AVULSAS

OUTROS

O FILME

Explico ao senhor: o

diabo vige dentro do

homem, os crespos do

homem - ou é o homem

arruinado, ou o homem

dos avessos. Solto, por

si, cidadão, é que não

tem diabo nenhum.

Nenhum! - é o que digo.

(...) Lhe agradeço. Tem

diabo nenhum. Nem

espírito. Nunca vi.

Alguém devia de ver,

então era eu mesmo, este

vosso servidor. Fosse

lhe contar... Bem, o

diabo regula seu estado

preto, nas criaturas, nas

mulheres, nos homens.

Até nas crianças. Pois

não é ditado: "menino -

trem do diabo"? E nos

usos, nas plantas, nas

águas, na terra, no

vento... Estrumes...O

diabo na rua, no meio do

redemunho...

(Grande sertão:

veredas. p.33 ) 


\section{O TEXTO}

Depois que morre, acabou. Acabou mesmo. Não tem nada, não. Nadinha de nada. Não tem como. Isso aí é história. De antigamente. Hoje não tem isso não.

- Mas parece que as pessoas boas, né?, Deus chama elas mais cedo. As pessoas boas Deus quer junto dele.

- O cara que não paga e o cara que paga, depois que morre, é tudo igual?

- Quem faz tudo certo vai pro céu e quem faz tudo errado vai pra baixo. Falam que lá você apanha, lá pega fogo... Mas não adianta. Tem uns que faz errado assim mesmo.

- Uns vai pro inferno, outros vai pro céu. Os maus também têm que ter um lugar. Lá no inferno agora tá cheio. Eles tão querendo soltar, agora.

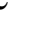


NOTAS AVULSAS

OUTROS

O FILME

Que isso foi o que

sempre me invocou, o

senhor sabe: eu careço

de que o bom seja bom e

o ruim ruim, que dum

lado esteja o preto e do

outro o branco, que o

feio fique bem apartado

do bonito e a alegria

longe da tristeza! Quero

os todos pastos

demarcados... Como é

que posso com este

mundo? A vida é ingrata

no macio de si; mas

transtraz a esperança

mesmo no meio do fel

desespero. Ao que, este

mundo é muito

misturado...

(Grande sertão:

veredas. p.?) 


\section{O TEXTO}

Meu coração tem

uma porteira que já

foi fechada e não vai

abrir mais não.

\section{AS CADERNETAS}

Eu tranquei meu coração

/ dei a chave pro meu pai

/ quem tá de fora não

entra / quem tá de dentro

não sai.

(p. 81)
O CONTO 
NOTAS AVULSAS

03.01.2013

Os velhos são

infinitamente mais

interessantes que os

jovens. Eles vêm ao

nosso encontro de

barba feita e camisa

passada. Seu Tonico

vai buscar o chapéu.

Carlinhos, o coveiro, chega meio bêbado. A dentadura não cabe na boca. Ele lembra o

Jim Carrey. Seu

Mauro e Seu Tonico

vêm de camisa de

colarinho azul clara, combinando com $\mathrm{o}$ cenário. Vão achar que foi encomendado. E ainda tem o chapéu de palha, pra dar um tom folclórico. Fazer o quê? Seu Nonô, apesar de franzino, tem pinta de galã. Não à toa ele teve 153 namoradas. 


\section{O TEXTO}

$\mathrm{Eu}$ fui assim muito namorista, assim, nos meus tempos de boemia, sabe? As moças parece que gostavam demais de mim. Se a gente falar, parece que o povo nem vai acreditar. Eu namorei 153 namoradas. Mulher solteira e moça, sabe? Vai contar, ninguém acredita. Aquilo era uma disputa das moças comigo. É uma coisa que ninguém acredita, é uma coisa que eu devia ter anotado num caderno. Essa que eu casei chamava Teresa. As outras chamavam Carmen, era Maria Lina, era Áurea Lúcia... Tinha a tal Joaquina, a Neusa, a Diva ...
O CONTO

1. Que o Pedro era ainda teimoso solteiro, e o maior bandoleiro namorador: as moças todas mais gostavam dele do que de qualquer outro; por abuso disso, vivia tirando as namoradas, atravessava e tomava a que bem quisesse, só por divertimento de indecisão. (pág 32)

2. E Pedro Orósio, pelo que tinha de esperar, repensava Laura, filha do Timberto, do Sacodo-Mato; e na Teresinha e na Joana Joaninha, do arraial; e em todas. A-prazer-de que não queria deixar de pensar também na Maria Melissa, do Cuba (p. 75) 
NOTAS AVULSAS

OUTROS

O FILME

28.12.2013

Depois de meses

estudando o conto, só

na hora da gravação

percebi que Pedro

Orósio não era Pedro

Osório. Foi só quando

ouvi a leitura do José.

A Ana me contou que,

durante muito tempo,

achou que o Morro da

Garça era Morro da

Graça. Essa é a graça. 


\section{O TEXTO}

É tanto que o povo

ficava até com inveja de

mim. Agora eu sou uma

pessoa que eu quero só

amizade com os outros.

Não quero briga com

ninguém. Não quero mal

querência com ninguém.

A gente já passou dos

60, não é? Então a gente

tem que caçar é união

com todo mundo. Por

que a gente vai até os 60,

mais ou menos, e aí já

começa a voltar pra trás,

a idade. Vai

enfraquecendo, vai

perdendo a força, vai se

tornando criança de

novo.

\section{AS CADERNETAS}

Tal modo que muitos

homens e rapazes lhe tinham ódio, queriam o fim dele, se não se atreviam a pegá-lo era por sensatez de medo, por ele ser turuna $\mathrm{e}$ primão em força, feito um touro ou uma montanha.

(p.32)

2. Contentava-o ver o Ivo abrir paz; coisa que valia neste mundo era se apagarem as dúvidas e quizílias. Toda desavença desmanchava o agradável sossego simples das coisas, rendia até preguiça pensar em brigar.

(p.33) 
NOTAS AVULSAS

OUTROS

O FILME

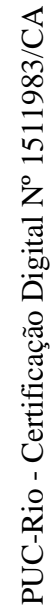




\section{O TEXTO}

E o povo, eles me negaram água! É por causa da minha voz. Eles não conseguem ouvir a minha voz. Porque o diabo, ele vem pra matar, roubar e destruir. Trazer tristeza, miséria. Então Deus me trouxe pra fazer o contrário, trazer o bem, a paz, a fartura. Então ele me odeia, né? $\mathrm{O}$ diabo. Ele quer me ver morto. Por causa que eu sou o ungido, o profeta, o escolhido. Tá vendo a minha voz?

\section{AS CADERNETAS}

O CONTO

- Vinde, povo:

senvergonhas, pecadores, homens e mulheres, todos. Todos eu amo, vim por vosso serviço, Deus enviou por mim, ele requer o vosso remimento.

(p.77) 
NOTAS AVULSAS

$\mathrm{Na}$ véspera de vir

embora, a descoberta

do Washington. Um

Nominedômine. Um

Bispo do Rosário. Ele

é “o ungido, o

profeta, o escolhido".

Ele é "poeta, cantor e

compositor". Ele faz

o inventário das

coisas do mundo. Ele

lista as coisas que ele

quer cantar. Ele

parece saído de uma

página do Guimarães

Rosa. Ele é a

realização de nosso

projeto inventariante.

Ele é a encarnação da

nossa imaginação. 


\section{O TEXTO}

Eu, eu tô na mão de Deus. Você tá na mão de Deus. Quando você tá no seu carro, você tá na mão de Deus. Quando você tá dormindo, Deus tá te guardando. Quando você tá alimentando, ele é que tá te cuidando. Deus é que tá alimentando. Quando você pisca e abre o olho, Ele é que tá permitindo você abrir o olho. Ele é que move você. $\mathrm{E}$ quando Deus fala: -Você não vai viver mais, Ele vai e apaga o seu espírito. Morreu. Aonde fala: morreu. 
NOTAS AVULSAS

OUTROS

O FILME

A espiritualidade -

afirmou-se - é,

sobretudo, essa

consciência do fato de

que o ser identificado

não está totalmente

identificado, mas ainda

contém certa carga de

realidade não-

identificada, que

importa não apenas

conservar, mas também

respeitar e, de algum

modo, honrar, assim

como se honram as

próprias dívidas.

(G. Agamben) 


\section{O TEXTO}

Foi Deus que trouxe você aqui e você não sabe. Seus passos são dirigidos por Ele. $\mathrm{O}$ espírito do homem é na mão de Deus! A profissão suas, que Deus deu a vocês, são poucas pessoas que falam que foi Deus que deu. Como os artistas - ator, atriz todos foram Deus que escolheu pra eles a profissão. É Deus que escolhe pra nós. É Ele que dirige, não é? Não é a gente que escolhe. Se a gente escolhesse todo mundo era rico!

Ele é que me dá a minha voz. Não é eu que falo o que eu falo. Ele é que dirige as minhas palavras.

A


Todo o impessoal em nós é genial; genial é, sobretudo, a força que move o sangue em nossas veias ou nos faz cair em sono profundo, a desconhecida potência que, em nosso corpo, regula e distribui tão suavemente a tibieza e dissolve ou contrai as fibras dos nossos músculos. É Genius que, obscuramente, apresentamos na intimidade de nossa vida fisiológica, lá onde o mais próprio é o mais estranho e impessoal, o mais próximo é o mais remoto e indomável. Se não nos abandonássemos a Genius, se fôssemos apenas $\quad \mathrm{Eu} \quad \mathrm{e}$ consciência, nunca poderíamos nem sequer urinar. Viver com Genius (cont. na p.44) 


\section{O TEXTO}

Quando você pisca e abre o olho, Ele é que tá permitindo você abrir o olho. Ele é que move você. E quando Deus fala: -Você não vai viver mais, Ele vai e apaga o seu espírito. Morreu. Aonde fala: morreu.

\section{AS CADERNETAS}

O CONTO

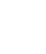

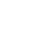

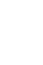

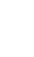


NOTAS AVULSAS
OUTROS

significa,

nessa

perspectiva, viver na

intimidade de um ser

estranho, manter-se

constantemente

vinculado a uma zona de

não-conhecimento.

(...) A intimidade com

uma zona de não-

conhecimento é uma

prática mística

cotidiana, na qual Eu,

numa forma de

esoterismo especial e

alegre, assiste sorrindo

ao próprio

desmantelamento e,

quer se trate da digestão

do alimento, quer da

iluminação da mente, é

testemunha, incrédulo,

do incessante insucesso

próprio. Genius é a

nossa vida, enquanto

não nos pertence.

(G.Agamben)

\section{O FILME}


TEXTO

Você tá vendo essa terra vermelha, aqui? Tudo o você que planta dá! Se você jogar uma semente de feijão, ela nasce.

Sem você fazer nada, sem cultivar. Só Deus é que faz ela germinar.

\section{AS CADERNETAS}

O CONTO 
NOTAS AVULSAS

04.01.2013

Quando Washington

apresenta a Bíblia como

"nosso manual", sinto

como se vivêssemos em

tempos, séculos, muito

diferentes, e tenho uma

espécie de inveja dele,

eu, que sinto como se

precisasse escrever meu

próprio manual.

\section{OUTROS}

O FILME

Num grão de areia ver o

mundo

$\mathrm{Na}$ flor silvestre a

celeste amplidão Segura

o infinito em sua mão

E a eternidade num

segundo

(William Blake) 


\section{O TEXTO}

Deus me deu o dom por

causa que eu vejo as

coisas que eles não

vêem. É uma visão que a

pessoa não vê

\section{AS CADERNETAS \\ O CONTO}


NOTAS AVULSAS

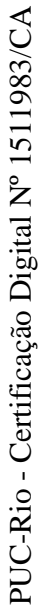

OUTROS

Vede, eis a pedra

brilhante dada ao

contemplativo; ela traz

um nome novo, que

ninguém conhece, a não

ser aquele que a recebe.

(Ruysbroeck. Epígrafe

Corpo de Baile)

\section{O FILME}

$$
\text { ao }
$$




\section{O TEXTO}

Porque eu já sei. Já sei o

que vai acontecer

comigo. Não tem como

eu tirar isso de mim.

Porque eu sou artista.

Sou poeta, cantor,

compositor.
AS CADERNETAS

O CONTO 
NOTAS AVULSAS
OUTROS

O FILME

A observação do artista

pode atingir uma

profundidade quase

mística. Os objetos

iluminados perdem os

seus nomes: sombras e

claridades formam

sistemas e problemas

particulares não

dependem de nenhuma

ciência, que não aludem

a nenhuma prática, mas

que recebem toda sua

existência e todo seu

valor de certas

afinidades singulares

entre a alma, o olho e a

mão de uma pessoa

nascida para

surpreender tais

afinidades em si mesmo

e para as produzir.

(Paul Valéry apud

Walter Benjamin) 


\section{O TEXTO}

Eu cheguei aqui, quando

eu cheguei aqui, eu

mostrei procê aquela

panela, uma

piquinininha? Era

aquela panela e o chão.

Só. E o resto: uma bolsa.

Aí, ó, o que você tá vendo aí, com dois anos que eu adquiri, eu adquiri catando essas coisas aí na rua. Fui catando esses negócio e pendurando aí. Fui catando, trazendo e colocando. Catando, trazendo e colocando. E assim eu tô indo, e vai ser assim até o fim, até eu morrer! É assim que eu vou fazendo. Porque eu sou artista, então

Deus me deu essa inspiração de fazer essas coisas. Só ando alegre. A minha vida é a simplicidade e as coisas. e 
NOTAS AVULSAS

OUTROS

O FILME

Onde há gente, como se

diz, há coisas. Quer isso

dizer que, admitindo as

primeiras, é necessário

admitir as segundas? É o

que resta saber. O que é

preciso evitar, não sei

por quê, é o espírito do

sistema. Pessoas com

coisas, pessoas sem

coisas, coisas sem

pessoas, pouco importa,

eu espero poder varrer

tudo isso em pouco

tempo. Não vejo como.

(Samuel Beckett) 


\section{O TEXTO}

Tudo significa, as

coisas. A lima é pra

comer a enxada; o

serrote; o disco da

maqueta; o arreio velho

do cavalo; a foice...

\section{AS CADERNETAS O CONTO}

.


NOTAS AVULSAS

A lima

A enxada

O serrote

$\mathrm{O}$ disco da maqueta

$\mathrm{O}$ arreio velho

A foice

\section{OUTROS}

O FILME

- E de que serve, então,

eles terem nomes, se não

atendem

por esses nomes? -

estranhou o Mosquito.

- Para eles, não serve de

nada - Alice explicou. -

Mas é útil para as

pessoas que dão os

nomes, eu acho. Se não,

por que dar nome às

coisas?

(Lewis Carroll) 


\section{O TEXTO}

Isso aqui é um

fogãozinho de lenha, significando, tá vendo? as coisinhas simples da terra... Essa vasilinha aqui é de fritar um ovo, chama frigideira, você já ouviu falar? Esse aqui, geralmente, eles usam aqui na roça co'o feijão, pra cozinhar o feijão, é o caldeirãozinho; essa botina é de sete léguas, de usar na roça, na água; essa telha é a melhor que tem, é o melhor telhado que tem, é a maior maravilha que Deus já criou no mundo. 
NOTAS AVULSAS

29.10.2013

Toda vez que ouço a

pergunta de

Washington: "Essa aqui

é uma frigideira, de

fritar um ovo, você

conhece, não é?” -

penso que ela é a

expressão de nossa

ignorância mútua em

sua dimensão mais

trágica: a de se

desconhecer aquilo que

se desconhece.

\section{OUTROS}

O FILME

Não podemos conceber, nos primórdios da vida reflexiva, que apenas as decisões arbitrárias permitem que o homem funde o que quer que seja: linguagem, sociedades,

conhecimentos, obras de arte.

(Paul Valéry ) 


\section{O TEXTO}

Esse pratinho aqui é esmaltado, de roça, caipira; a garrafinha de café...Esse canivete aqui é do cabo de osso, tá vendo? Esses osso aí que vocês tão vendo fabrica esse canivete aqui. Esse aqui é o bulezinho de café, significando...um jardim; essa aqui é a tampa da lata de leite, a boca da lata de leite, o selim da bicicleta...

Essa aqui é a máquina de plantar arroz, ó, tá vendo? $\mathrm{O}$ arroz é plantado dentro dessa máquina. Essa aqui é a enxada pra limpar o arroz. Essa cabaça aqui significa garrafa de água dos trabalhador, que eles levava, antes, pra roça. (n) 
NOTAS AVULSAS

Fogãozinho de lenha:

frigideira

caldeirão

bota de sete léguas

telha

pratinho esmaltado

garrafa de café

canivete

ossos

bule de café

tampa da lata de leite

selim de bicicleta

máquina de plantar

arroz

enxada

cabaça

\section{OUTROS}

Quando uso uma palavra

- disse Humpty Dumpty

num tom desdenhoso -

ela significa exatamente

aquilo que eu quero que

signifique... nem mais,

nem menos.

- A questão - ponderou

Alice - é saber se o

senhor pode fazer as

palavras dizerem coisas

diferentes.

- A questão, replicou

Humpty Dumpty - é

saber quem é que

manda. É só isso.

(Lewis Carroll)

\section{O FILME}

.




\section{O TEXTO}

Essa bolsa aqui significa

quando eu saí daqui, ó, quando eu fui embora. O chinelim, mostrando também que eu era criança, quando eu saí. E essa caixinha eu pus aí pra receber as correspondências... E aqui tem um violão, ó. Eu catei uns pedaços de tijolo, e falei: eu vou fazer um jardim, aqui. 


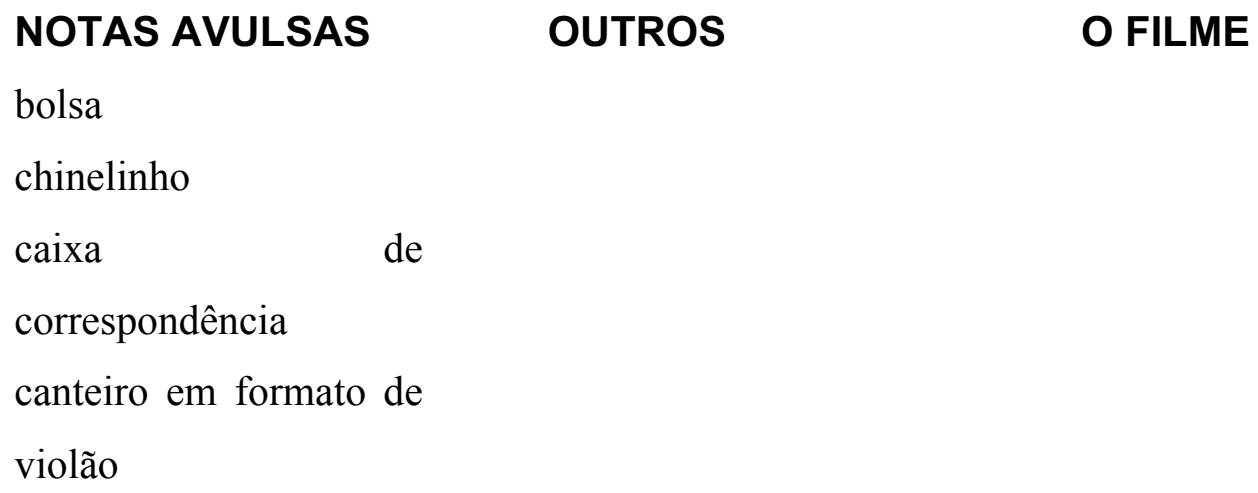




\section{O TEXTO}

Esse fogão aqui, tá vendo? Isso pra mim é uma coisa que não tem... no mundo nada tem valor mais que isso aqui pra mim. Porque aqui você faz tudo. Tudo aqui você faz do mesmo modo que você faz lá num de 6 bocas você faz nesse aqui. (...) Essa comida aqui é uma comida caipira, tá vendo? Costela de boi com batatinha.

\section{AS CADERNETAS}

O CONTO

E se comia uma ceia bôa: de sopa-debatatinha com bastante sal, com folha verde de cebola picada, e brôa de milho; depois, leite frio no prato fundo, com queijo em pedacinhos e farinha-de-munho.

(p.74) 
NOTAS AVULSAS

OUTROS

O FILME

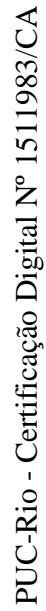




\section{O TEXTO}

E essa música minha,

que tá aqui na minha

cabeça, Ele me escolheu

porque eu vou falar das

flor, das madeira, das

folha, do verde, do

amarelo, do azul. Das

mulheres, da memória,

da cabeça, do coração,

do rancho, do prédio.

Das ruas, das estradas, do asfalto, da terra, dos passarim... De todas as coisas.

\section{AS CADERNETAS}

O CONTO

Enxacoco e desguisado nos usos, a tudo quanto enxergava dava um mesmo engraçado valor: fôsse uma pedrinha, uma pedra, um cipó, uma terra de barranco, um passarinho atoa, uma moita de carrapicho, um ninhol de vêspos.

(p.28) 
NOTAS AVULSAS

03/03/2013

O filme não é sobre

nenhum tema ou

pessoas. $\mathrm{O}$ conto

circunscreve um espaço

no interior do qual tudo

nos interessa, sem

hierarquia: pessoas,

estórias, insetos,

canções, carros de boi,

formas de tijolo, festas

populares...

\section{OUTROS}

Graças quero dar ao

divino / labirinto dos

efeitos e das causas/

pela diversidade das

criaturas / que formam

este singular universo,/

pela razão, que não

cessará de sonhar/

com um plano do

labirinto,/ pelo rosto de

Helena e a perseverança

de Ulisses,/ pelo amor

que nos deixa ver os

outros/ como os vê a

divindade,/ pelo firme

diamante e a água solta,/

pela álgebra, palácio de

precisos cristais,/ pelas

místicas moedas de

Ângelo Silésio,/ por

Schopenhauer/ que

decifrou talvez 0

universo,/ pelo fulgor do

fogo/ que nenhum ser

humano pode olhar sem

um assombro antigo,/

pelo acaju, o cedro e o

(cont. na pág.66)

O FILME

s

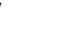

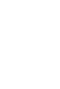




\section{O TEXTO}

Da natureza, das

diferenças das frutas.

Das diferenças das

folhas das árvores, os modelos... Então, são

muito diferente as

criação de Deus. As

folhinhas, cada uma é de

um modelo; um verde de uma cor, um verde de outra, o azul, as cores que ele criou. 
NOTAS AVULSAS

As flores

As Madeiras

As Folhas

O Verde

O Amarelo

O Azul

As Mulheres

A Memória

A Cabeça

O Coração

O Rancho

O Prédio

As Ruas

As Estradas

O Asfalto

A Terra

Os Passarinhos

As Frutas

As folhas

As Árvores

Um verde

Outro verde

O azul

As cores

\section{OUTROS}

sândalo,/pelo pão e o

sal, / pelo_mistério da

rosa/ que prodigaliza

cor e que não a vê, / por

certas vésperas e dias de 1955,/ pelos duros tropeiros que, na planície,/ arreiam os animais e a alba,/ pela manhã em Montevidéu/ pela arte da amizade, pelo último dia de Sócrates,/ pelas palavras que em um crepúsculo se disseram/ de uma cruz a outra cruz,/ por aquele sonho do Islão que abarcou/ mil noites e uma noite,/ por aquele outro sonho do inferno,/ da torre do fogo que purifica/ e das esferas gloriosas,/ por Swedenborg,/ que conversava com os anjos nas ruas de Londres,/ pelos rios secretos e imemoriais/ que (cont. na pág.68) 


\section{O TEXTO}

Eu vou falar de coisa

que homem nenhum

falou ainda. Das cascas

da madeira, os desenhos

dos paus, os frisos,

entendeu? A música, a

formiga, o cupim, o

carrapato, essas coisas.

Das pedras. Da

humildade, da

simplicidade, do

respeito, da verdade, da

sinceridade, dessas

maravilhas. Do amor, da

fidelidade, de tudo! Do

anzol, do bambu, tudo!

Eu vou falar de tudo que

meu Pai criou.

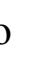


NOTAS AVULSAS

As cascas da madeira

Os desenhos dos paus

Os frisos

A música

A formiga

O cupim

O carrapato

As pedras

A humildade

A simplicidade

O respeito

A verdade

A sinceridades

O amor

A fidelidade

$\mathrm{O}$ anzol

O bambu
OUTROS

O FILME

convergem em mim,/

pelo idioma que, há

séculos, falei em

Nortúmbria,/ pela

espada e a harpa dos

saxões,/ pelo mar que é

um deserto

resplandecente/ e uma

cifra de coisas que não

sabemos/ e um epitáfio

dos vikings,/ pela

música verbal da

Inglaterra,/ pela música

verbal da Alemanha,/

pelo ouro que reluz nos

versos,/ pelo épico

inverno,/ pelo nome de

um livro que não li: /

Gesta Dei per Francos,/

por Verlaine, inocente

como os pássaros,/ pelo

prisma de cristal e o

peso de bronze,/ pelas

riscas do tigre, / pelas

altas torres de São

Francisco e da ilha de

Manhattan,/ pela

(cont. na pág 70) 
O TEXTO

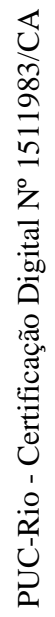

AS CADERNETAS

O CONTO 
NOTAS AVULSAS

OUTROS

O FILME

manhã no Texas,/ por

aquele sevilhano que

redigiu a Epístola

Moral/ e cujo nome,

como ele teria

preferido, ignoramos,/

por Sêneca e Lucano,

de Córdoba,/ que antes

do espanhol

escreveram/

toda a literatura

espanhola,/ pelo

geométrico e bizarro

xadrez,/ pela tartaruga

de Zenão e o mapa de

Royce,/ pelo odor

medicinal dos

eucaliptos,/ pela

linguagem, que pode

simular a sabedoria,/

pelo esquecimento, que

anula ou modifica o

passado,/ pelo costume,/

que nos repete e nos

confirma como um

espelho,/ pela manhã,

que nos depara a ilusão

de um princípio,/

(cont. na pág 72) 
O TEXTO

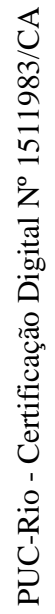

AS CADERNETAS

O CONTO 
OUTROS

pela noite, sua treva e

sua astronomia,/ pelo

valor e a felicidade dos

outros,/ pela pátria,

sentida nos jasmins/ ou

numa velha espada,/ por

Whitman e Francisco de

Assis, que já

escreveram o poema,/

pelo fato de

que o poema é

inesgotável/ e se

confunde com a soma

das criaturas/ e jamais

chegará ao último

verso/ e varia segundo

os homens,/ por Frances

Haslam, que pediu

perdão a seus filhos/ por

morrer tão devagar,/

pelos minutos que

precedem o sonho,/ pelo

sonho e a morte,/ esses

dois tesouros ocultos,

/pelos íntimos dons que

não enumero,/ pela

música, misteriosa

forma do tempo.

(Jorge Luís Borges )

O FILME 


\section{O TEXTO}

Ah, pássaro tem muito, tem demais. Ichi! De pequenininho a grande, nesse pantanal aí, o que não falta é pássaro. Tem muita garça, tem aquele pato, aquele preto $\mathrm{e}$ branco, tem o paturi, tem o marreco, tem a saracura... Tem demais! Aqui tem muito é pássaro! Gavião tem muito. Carcará tem muito. Urubu... Esses passarozinhos pequenos tem demais. Tem joãode-barro, maritaca, essa pomba verdadeira, tem juriti. Tem demais.

\section{AS CADERNETAS}

1.Aqui tem: o pássaro preto baiano (pintado de amarelo e preto, como o sofrê; canta mais bonito que o sofrê).

No brejo: garças; o monjolinho, do tamanho do galo do campo, mas "tem muito mais pernas".

O MONJOLINHO: tem

o bico preto, comprido,

e o pescoço comprido, que fica pendendo $\mathrm{e}$ batendo, feito um monjolo. (p.179)

2. Bando de juritis tantas e tão junto de casa ( Não são juritis: são pombas “verdadeiras"! ).

(A pomba verdadeira é arisca. Nunca se deixa pousar ou ficar ao alcance do tiro da gente. Só tocaia ) (p.35)

\section{O CONTO}

Papagaios rouco gritam: voam em amarelo, verdes. Vez em vez, se esparrama um grupo de anús, coracóides, que piam pingos choramingas. O caracará surge, pousando perto da gente, quando menos se espera _um gaviãoão vistoso, que gutura.

(p.31) 
NOTAS AVULSAS

OUTROS

O FILME

Passarinhos. Muitos

passarinhos.

Cachorros e bois

super presentes.

Marimbondos,

formigas, abelhas,

aranhas, cigarras,

cupins, lagartixas,

besouros, lagartos.

Os rádios ligados.

Celulares

onipresentes. 
O TEXTO

Ư

\section{AS CADERNETAS}

Galinha e pintinhos,

entre as patas das vacas,

no curral. A galinha

cata carrapatos entre as

têtas. Joga os carrapatos

no chão, para os

pintinhos.

(p.176)

\section{O CONTO}


NOTAS AVULSAS

OUTROS

O FILME

As galinhas. As

galinhas rodam o

mundo inteiro e voltam

pra minha casa. Elas

não misturam com as do

vizinho, não. Se ela é

minha, ela não vai

dormir na casa da

vizinha. Elas podem

andar com as galinhas

da vizinha que, de noite,

de tardinha, cada qual

vai pro seu canto. 


\section{O TEXTO}

Essa é a cagaiteira, a

folha seca pra fazer o

chá é bom demais pro

rim que ele é muito

fresco. Tem a

cervejinha, é uma raiz. É

a cerveja mesmo. Você

arranca a raiz dela, põe

ela pra secar, aí bate ela,

põe ela na água, vai

pondo assim, ela escuma

igual a cerveja, mesmo.

Pro rim você nunca viu

bom desse jeito! É

fresquinho e bom e até

bom pra gente tomar.

Tem o cajuzinho, é um

pequenininho, ele dá

sempre mais é na

chapada, sabe? Pra

diabete é bom demais.

\section{AS CADERNETAS}

Cólica de fígado:

mastiga a folha ( o talo também ) do funcho, depois bebe um gole de água quente!

(p.27)

\section{O CONTO}

Colhia com duas mãos a

ramagem de qualquer

folhinha campã sem

serventia para se

guardar: de marroio,

carqueja, sete-sangrias,

amorzinho-seco, pé-de-

perdiz, joão-da-costa,

unha-de-vaca-roxa,

olhos-de-porco, copo-

d'água, língua-de-

tucano, língua-de-teiú.

(p.31) 
NOTAS AVULSAS

OUTROS

O FILME

Cagaiteira

Cervejinha

Cajuzinho 


\section{O TEXTO}

Tem o pacari, pra gastrite. Mas tem que tomar pouco. Põe ele, assim, numa vasilha de louça - porque se colocar ele numa vasilha que ele empretece, não pode tomar. Que ele é veneno. Ele é remédio e é veneno. Agora, pondo numa vasilha de louça, pode tomar. E, assim, não toma muito, não. É bom pra gastrite, bom pra qualquer inflamatório. E também tem o nharé pro sangue. Esse é uma fruta, muito gostoso. Arranca a raiz dele e faz o chá. Pro sangue, pra pele, você nunca viu bom desse jeito.

\section{AS CADERNETAS}

O CONTO

1.Ramo de pacarí lindo, com frutas côr de vinho, estriadas, e flores de cálice muito colorido, pétalas, amarelo frio, xxxxxxx e longuíssimos estames cabeçudos, antenares, transbordantes (p.184)

2.Nharé: árvore. ( Estamos no cerrado ) ( NHARE' ). pág 119

Nharé ou mama-cadela: arbusto do cerrado ( dá até um frutinho, qua gente come).

(p. 33) 
NOTAS AVULSAS

Pacari

Nharé

Pau-do-touro

Canelinha-de-perdiz

Capitão

Alecrim

Maracujá

Erva cidreira

Poejo:

São caetano

Artemijo

Hortelã pimenta

Trançagem

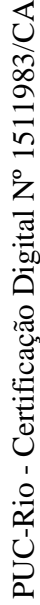

Camará-do-reino:

Favaca

Quitoco 


\section{O TETXO}

A lua, quando ela é nova, ela não fica assim?

Um risquim? Aí quando

ela tá marcando chuva, ela fica assim, ó. Você pode olhar. Ela dá um circulozinho ao redor dela: chuva longe. Quando dá o círculo longe, aí a chuva é perto. Se tiver pra chover, pode esperar que vai chover. O cupim reforma o cupim. Isso aí você pode esperar chuva. O pauterra não cai na poeira, e nem a cagaita. E os passarim também adivinha. Tem o raparapa, igual tem aqui, que fica cró-cró-cró... Tem um passarim aqui, que se tiver chovendo e ele começar a cantar, um tal de peixe frito, não sei se você já escutou, de noite ele gosta de cantar: peeexx-fritu. Ah! É sol purim!

\section{AS CADERNETAS}

Sinais de chuva:

i) quando o tesoureiro (pássaro) aparece, é que está vesprando chuva.

ii) quando o sabiàzinho (pardo) pequeno, menor que um joão-de-barro ) canta muito. (É pássaro da beira do córrego).

iii) os sapos

(p.?)

\section{O CONTO}

Criatura pra conversar fiado nunca falta: como é que um podia afirmar, em mês de agosto, se as chuvas do ano vão vir mais cedo ou mais tarde?

(p.90)

\section{.}


NOTAS AVULSAS

Tento localizar a

origem, o início. Um

velho vício, fora de

moda. Mas a cada vez

que eu penso, o inicio

recua mais um pouco.

Então suponhamos que

tudo tenha começado no

dia em que eu entrei na

Dantes e, não sei por

que motivo, saí com um

livro chamado "Os

roceiros - Histórias e

lendas do sertão".

Um parágrafo escrito

numa linguagem tosca -

uma imitação grosseira

e caricatural da fala dos

"roceiros" - trazia uma

longa lista de sinais de

chuva, ao final da qual

eu pensei: - Nossa,

como sou ignorante!

Mas isso foi há mais de

10 anos.

\section{OUTROS}

O FILME

minhoca sai da terra

maritaca volta pra serra

laranjeira fica com o

broto virado

tanajura aparece

formiga miúda cria asa

abóbora murcha a flor

céu fica cheio de rabo de

galo

carne seca pinga

bezerros ficam de rabo

em pé

sol fica encapelado

água da cachoeira baixa

cavalo sua na sombra

gato lava a cara

barbado ronca no mato

(Os roceiros) 
O TEXTO

AS CADERNETAS

\section{O CONTO}

Seo Olquiste agora

desenhava na caderneta

as alpercatas do catraz, era o que ele portava de mais imponente. 
NOTAS AVULSAS

Mas como o inicio não

para de recuar, acabei

chegando, de novo, num

naturalista alemão: o

Dieter. O Dieter era

marido da Marili, que era

mãe da Maria, que era

amiga da Martha, que era

casada com o Dudu, que

era meu irmão. Então,

devo minha ida ao Dudu,

que deve à Martha, que deve à Maria que deve à

Marili que deve ao

Dieter, geógrafo e

alemão, que foi pra lá,

pela primeira vez, pra

fazer pesquisa de campo,
OUTROS

O FILME

Você já viu precata de couro? Uma precata que eles fazem de pneu, lá? Só que ela não é enfiada, assim, não. Tem um negócio que vem até aqui, aí você enfia uma corda, aqui, que passa, aqui, e vem cá atrás. Eles falam precata de retranca. Você pode pisar assim que ela não fica batendo, não. Você sabe como é que eles tratavam ela antigamente? $\mathrm{O}$ povo chamava ela de salga bunda. Sabe por que? Porque quando você vai caminhando, assim, ela vai jogando areia na bunda da gente, vai jogando pedrinha na gente. Só que a retranca não faz isso, não, porque ela passa aqui e prega atrás. 


\section{O TEXTO}

Esse aqui é o adobo. Não

era cimento naquela

época, não. Fazia a

massa com areia e bosta

de boi, misturava, fazia

aquela massa e passava

na parede com a colher.

Era desse jeito. Era

adobe. Adobe de barro.

Sem queimar. Era maior

assim. Mais grosso. Não

é igual a tijolinho não.

Era do próprio barro.

Era pesado esse adobe.

Tinha que pegar com as

duas mãos pra colocar

na parede, né? Fazia

primeiro com a forma de

tábua, ai secava, e agora

já colocava na parede ele

seco, não é? E

continuava a fazer as

paredes com ele. E

rebocava por fora com a

massa de bosta de boi

com areia.

\section{AS CADERNETAS}

O CONTO

Casa ( copiar )

Esteio central

Espigões

Caibros

Ripas

Cumeeira

( A cumeeira horizontal, por cima, Com os dois p's-direitos, forma uma espécie de barra. Da cumeeira, onde ela toca os pés direitos - partem, oblíquos, dois em cada extremo, os espigões. Da cumeeira, oblíquos, vários de cada lado, partem também os caibros. As ripas cruzam os caibros, transversalmente).

(p.82) 
NOTAS AVULSAS

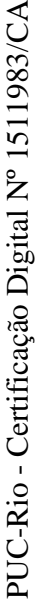

OUTROS

E aí nessa vida eu comecei trabalhando de carapina também. Carapina é esse tipo de madeira, assim, alguém que faz madeira, prepara pra construir. Tem que ser os esteios primeiro. Depois é que faz as paredes. É o esteio que garante a casa. Essa madeira assim chama engradamento, travamento. Então ela trava que não abre, a parede não racha. 
O TEXTO
AS CADERNETAS

1.FOLIA (Sertão)

A regra é 6 ( seis ) vozes.

Seis (6) companheiros

só para cantar, afora os

tocadores. Tocadores

sempre é 7: cavaquinho, violão, rabeca, duas

violas, uma caixa ( de

bater ) e um pandeiro.

Dois palhaços: roupas

diferentes. Máscaras

feias. Um é o palhaço

velho, o "Guarda-Môr":

paletó preto e calça

branca. Capacete de

papelão, preto, enfeitado

com galão amarelo, só.

Paletó com cruz de

galão ( amarelo ) nas

costas. Máscara branca,

nariz grande. Bigodudo

( bigode clarinho, de

seda de animal.). O

outro é o "Bastião", todo

de vermelho. Máscara

preta. Nariz chato. Todo

feio. Roupa vermelha, paletó apertadinho,

(cont. na pág.89)

\section{O CONTO}

Também muitos já revestidos, para figurar na festança do diaseguinte. Os dos ranchos: os moçambiqueiros, de penacho e com balainhos e guizos prendidos nas pernas; grupos congos em cetim branco, e faixa, só faltando os mais adornos; e a rapaziada nova, com uniforme da guarda-marinheira.

(p.81) 
NOTAS AVULSAS

26.12.2012

A Folia de Reis sai da casa da Dona Vilma e passa, em seguida, na casa do Seu Tico. Depois viaja, de ônibus, pra outro lugar. A casa da D. Vilma é pequena e está abarrotada. Estamos espremidos entre os convidados e vai ser difícil filmar o que quer que seja. Nossa presença não chama especial atenção. O resto é mais importante, parece. Melhor assim. O presépio da casa dela é high-tech. Os músicos usam camisetas com a marca da Folia estampada. Os Reis usam roupas de cetim: azul, vermelho e amarelo. E máscaras. As máscaras são meio assustadoras, mas eles só cobrem o rosto na hora da encenação. 
O TEXTO

\section{AS CADERNETAS}

como de mulher ( blusa

); calça apertadinha e

curta, barrada com uma

renda branca. $\mathrm{Na}$

cabeça, boné vermelho, chato - um gorro, mais ou menos; com um espelho na testa, colado. ( No Bastião, tudo é mal feito. No Guarda-mór, não. $\mathrm{O}$ velho precisa de ser sério. Porque é o que manda. O "Bastião" é reprecho, "saído". O Guarda-Mór carrega num pau a abandeira dos Três Reis - estampa posta num pano. Tem o gerente da Folia. A Folia é dele.2. Canto da Folia Boa noite, oh de casa / A quem nesta casa mora.../ A quem nesta casa mora / os três reis lá do Oriente / os três reis que chegaram primeiro / lá da parte do Oriente / da parte do Oriente.(com outra voz) (p. 94 e 95)

\section{O CONTO}

\section{a}


NOTAS AVULSAS

OUTROS

O FILME

A música é repetitiva e triste. Meio mantra, meio ladainha. A plateia participa e grita nos momentos mais animados. Um pai-nosso antecede o início da brincadeira. 


\section{O TEXTO}

1. Cadê que o mundo acaba! Acaba pra quem morre! O pessoal falou que ia acabar no dia 21 agora. Aí eu levantei cedo, palpei eu, e falei: Ops, minha mãe, tô vivo! Olhei pra riba e admirei: olha o sol aí, minha gente!

2. Desde que eu era menino, o povo fala que o mundo vai acabar. Agora veio essa noticia, de novo. Acabou em água, uma vez, agora vai acabar em fogo.

\section{AS CADERNETAS}

O CONTO

- Às almas, meus irmãos! O fim do mundo, mesmo, já começou, por longes terras. E vem vindo... Olha os prazos! (..) Vocês mesmo não notam: mas a alma de cada um já começou a ficar adormecida...Olha os prazos! Olhem para os bichos, por comparação...

(p.79) 
NOTAS AVULSAS

$\mathrm{O}$ calendário maia anuncia o fim do mundo para o dia 21 de dezembro de 2012. Ótimo motivo pra puxar o assunto "fim de mundo" que aparece tantas vezes no conto. Chego em Morro da Garça no dia 22. Pena. Já tendo passado o perigo, eles não confessam o medo. Tivesse eu chegado na véspera e as respostas teriam sido bem outras.

\section{OUTROS}

A cidade de Morro da Garça dista cerca de 200 km de Belo Horizonte, na região centro-norte de Minas Gerais, estando localizada no centro geodésico do estado. (...) $\mathrm{O}$ povoamento da região teve origem no início do século XVIII, como caminho de boiadeiros no circuito entre a Bahia até a vila de Sabará, (...)A denominação do lugar deveu-se à existência da elevação rochosa homônima, a mais elevada da região com cerca de $1.000 \mathrm{~m}$ de altitude, onde ao seu sopé ficava a Fazenda da Garça. (...) o arraial se formou em torno da capela de Nossa Senhora das Maravilhas, construída em 1720 nas terras da referida fazenda.

(Revista Geonomos) 


\section{O TEXTO}

Eu não acreditei porque

eu sei que o mundo não vai acabar. Mas aqui teve gente que achou que acabava. Teve gente que vendeu lá muita coisa com medo de acabar. Teve gente que tava até adoecendo de medo. Teve gente que nem na rua saiu.

- Teve um sujeito que chegou lá na minha casa, aquele solão, e ele: - “Ô amigo, o mundo vai acabar! Não adianta a gente trabalhar que nós vamos morrer de fome, de sede, assado, cozido, torrado no sol!" Até chorar ele chorou. E eu rindo...deixa de ser bobo caboclinho!

\section{AS CADERNETAS}

O CONTO

1. - O mundo já começou a se acabar, e vós semprando na safadeza, na goiosa! (...) Olha o enquanto-étempo...

(pág.77)

2. Olha o aviso: evém o fim do mundo, em fôgo, fôgo e fôgo!

(p.77) 
NOTAS AVULSAS

OUTROS

O FILME

Os sete Anjos com as

sete trombetas se

prepararam então para

tocar. E o primeiro

tocou...Caiu então sobre

a terra granizo e fogo,

misturados com sangue:

uma terça parte da terra

se queimou, um terço

das árvores se queimou

e toda vegetação verde

se queimou.

(Livro do Apocalipse) 


\section{O TEXTO}

- O mundo acaba é pra quem morre. De vez em quando vai um. Depois vai um punhado. Uns morrem de trombada, outros morrem caído n'água, outros morrem de queda de avião... Bate um caminhão aí, tomba aí, capota aí... Pra esse o mundo acaba.

- Eu tenho pra mim que vai acabar nós, o mundo não acaba, não. Enquanto tiver mulher ganhando menino, vaca tendo bezerrinho, eles dizem...que tiver dando flor, não precisa ter medo que o mundo não acaba, não...E nunca começou também não... teve sempre aí. Tem escrito no catecismo: o mundo não teve princípio e nem terá fim. O mundo velho é muuuncho mundo!

\section{AS CADERNETAS}

O CONTO

- Lá é Cristo, e cá é isto..." ( Manoelzão )

-“Lá chove, e cá corre..."

- O mundo acaba é pra quem morre.

(p.185) 
NOTAS AVULSAS

20.12.2012.

1 Panasonic HVX200. 1

Canon 5D. 1 Canon mini

HDV. Microfone de

lapela. Boom. Gravador.

Cartões de memória.

Tripé. Computador.

Cabos. Bateria.

Carregador. Uma equipe

recrutada entre amigos e

familiares, e algumas -

não muitas - ideias na

cabeça: procurar

reverberações do conto

no lugar; embaralhar as

fronteiras

entre

documentário e ficção;

realizar um experimento

de linguagem fílmica

sobre a linguagem

verbal.
OUTROS

O FILME

Não fui feito pra viajar,

bolas! Estou sorrindo,

,mas por dentro de mim

vai um arrependimento

assombrado, cor de

incesto. Entro na

cabina, agora é tarde, já

parti, nem posso me

arrepender. Um vazio

compacto dentro de

mim. Sento em mim.

(Mario de Andrade) 
4

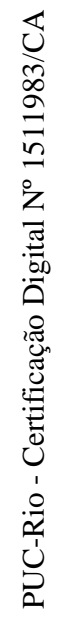


TUDO SIGNIFICA, AS COISAS 
Com as vozes de:

Antonio Rodrigues Lopes Carlos Alberto Santos Sousa Carlos Roberto Diniz Conceição Alves da Rocha Geraldo Magela Lucio Geraldo Nonato da Cruz João Guimarães Rosa Mario Magdaleno de Oliveira Suzana Teixeira de Macedo Washington Gomes de Avelar 
Método deste trabalho: montagem literária. Não tenho nada a dizer. Somente a mostrar. Não surrupiei coisas valiosas, nem me apropriei de formulações espirituosas. Porém, os farrapos, os resíduos: não quero inventariá-los, e sim fazerlhes justiça da única maneira possível: utilizando-os. 


\section{LEGENDA}

Seu Tonico $=$ vermelho Seu Mauro = azul

Magela $=$ ocre

Seu Nonô $=$ verde Seu Nonato $=$ azul claro Carlinhos $=$ vermelho escuro Cacá $=$ roxo

Washington $=$ cinza

Suzana $=$ preto

O Recado do Morro = preto itálico 
- Eles eram uns 8 companheiros. E mais a peãozada. Os dois velhos parece que eram os capatazes, né? Esses dois é que comandavam a turma toda. Onde eles gritassem que era pra parar, até o guia lá adiante tinha que parar com o gado. $\mathrm{O}$ gado deles era só gado macho, gado novo, gado esperto... Mas tava tudo cansado, já, com a orelha pendurada, de tanto andar. Aí eles chegaram com a boiada e pousaram lá nessa fazenda onde nós tava, lá, no Catatau, no Geraisão, lá. Nessa época eu era menino de escola, ainda. Chegaram lá com a peãozada, um gadão, aterrissaram lá, pousaram lá... Aí essas meninas faladeiras foram lá receber eles... E eles gostaram!... Eles eram gente estranha e aceitaram elas de bom coração. Aah! Aí elas tomaram conta que nunca mais pararam de conversar... E eu só olhava, assim, de longe, e essas meninas grudadas lá. Se nós não dana com elas, nem dormir elas não iam, lá pra dentro. Ficavam lá, quentando fogo, a noite toda, mais esses homens. E quanto mais elas falavam, mais eles gostavam também. Eu já tinha ido lá conversar com eles. Um menino lá, companheiro nosso, levou até milho pro homem dar pra mula dele. Cada espigão! Descascava e quebrava no meio e dava o bicho pra comer com sabugo e tudo. E nós lá, olhando e rindo. Aí fizeram um fogo. E ele com uma cadernetinha, assim, em riba da perna, assim, perguntando o nome de todo mundo e escrevendo. O nome delas foi os primeiros. Depois foi buscar nós. Depois buscar papai. Depois buscar os meninos lá da Diva. E foi escrevendo o nome de tudo! E esse povo era olhando os bichos também. De manhã cedo, quando nós ia pro curral beber leite, eles iam lá pra olhar o quê que nós tava fazendo. Beber leite cru tirado direto da vaca e bebendo. Aí o menino falou: - "Vocês vão aceitar leite? Eu vou buscar o copo e o Senhor bebe!” E ele: - "Não, o leite é muito bom, mas nós não vamos aceitar, não. Beber leite, não.” E as vaca asseadinha, limpinha... Não tinha carrapato, não tinha berne, não tinha nenhuma perebinha, nada. Eles olharam, olharam, mas beber o leite não queriam, não. Aí no outro dia ele falou: “Ó, Carnelygia, você, mais a Diva, nós tamo indo embora, mas tamo levando aqui essa escrita, o nome desse povo todo aqui,! Tá tudo escrito aqui pra mó de fazer um livro! Do lugar onde nós andamos." Aí eu perguntei onde é que eles iam passar: "Nós vamos sair por esse Gerais aí afora... Na Serra das Cabras nós vamos subir; na Serra do Cruzeiro nós vamos descer; nós vamos pousar lá pro lado do Riacho das Vacas... E vamos descer por aí abaixo, vamos caçar Bicudo por aí abaixo...” E 
esse povo andando, na lida... Esse povo andou foi um bocado nesse mundo! O Manuelzão e o Guimarães Rosa. Agora eu não sei é onde eles foram parar...

\author{
Em cima daquele morro \\ Ah, morena! \\ Eu vi o mutum gemer, oi-iá \\ Eu vi o mutum gemer \\ Ah, morena! \\ Meu corpo todo tremer, ai, ah!
}

- Existe Deus, também. Existe. Existe o céu, existe Deus morando lá, existe o capeta, também, existe o inferno, também. Não precisa ninguém duvidar, não, que tem de tudo, tem. Tem hora que a felicidade parece que não é toda hora não. Tem hora que a gente tá alegrezinho, aí, de repente, topa um trem de mal jeito... Aí, quando vê, a gente tem que enfezar depressa demais. Então, tem esse trecho também. Tem as partes boas e tem as partes ruins. Tem umas horas que a gente não é muito feliz mesmo não. Se a felicidade fosse direto, ninguém acreditava que tinha o capeta!

\author{
Lá vai a Garça voando \\ Com a pena que Deus lhe deu \\ Penando pena por pena \\ Mais pena padeço eu
}

- Eu fui nascido lá pros lados dos Gerais, lá. Lá só tinha era vereda, era campina, era só gorgulho de pedra e capim barba-de-bode... Esse trem era o Gerais. Cerradinho baixo, raso. É o Geraisão. Areia... Eu tava com um ano e dois meses quando começou a vida ruim. Deus levou mamãe e eu fiquei com um ano e dois meses. Deus não quis levar eu não. Tudo de ruim no mundo aconteceu comigo. Que menino sem mãe é só de sofrer. Eu fiquei doente até inteirar 2 anos. Diz que os mosquitos andavam dentro dos meus olhos que eu nem mexia. Quando eu dei conta de levantar, um avô pegou eu, levou eu, criou eu. Então, um dia tava muito bom, outro dia tava pior, outro dia tava mais ou menos... E quebra a orelha de um lado, quebra a cara de outro, e lá vai vivendo... Eu era um menino bom da ideia, um 
menino bom de mexida, inteligentezinho... Um bichinho macho, bem quentezinho, bem bonzinho... Até que papai carregou eu de lá. Tirou eu do céu e levou eu pro inferno. Essa bocaina era um lugar feio, bravo. Era serra dum lado, serra do outro e um córrego beirando a serra. Na outra serra era só grotão feio e bicho perigoso e tudo o que era trem feio. Tinha onça, tinha tudo que era qualidade de cobra braba, tinha tudo quanto era bicho ruim. E papai largava nós lá. E nós era só dois. Arroz a gente tinha que socar no pilão, lenha a gente tinha que buscar no mato, água a gente tinha que buscar também. Eu tinha uns 10, 12 anos, ia pra escola, caminhava uma, duas léguas pra chegar na escola, todo dia, então eu sofria muito. E a vida foi continuando. E papai judiando de mim e eu sofrendo, sofrendo...Ah! Aí eu embrabeci. Embrabeci mesmo. Embrabeci de um jeito que eu não prestei mais. Virei burro bravo, endureci o queixo, o pescoço... Em vez de aprender ler, eu aprendi foi brigar. Aí quando eu aprendi a brigar eu achei melhor. Eu falei: - "Eu já sofri que chegue. Agora eu vou é cacetar um bocado de trem também.” E eu fiquei igual aqueles galinho inchado, redondozinho. E toda hora eu queria uma briga. Topava mesmo. Então eu continuei a vida. Trabalhava de enxada, plantando roça eu trabalhava com lata de matar lagarta, de bater veneno em planta - eu entrei sempre dentro dos perigos... Trabalhei no curral tirando leite. Trabalhei em bateção de pasto. Carreei lenha pra carvoeira, trabalhei de peão... Depois quando eu fui trabalhar de peão, quando eu virei bicho doido, aí eu achei gostoso! Agora eu achei gostosa a vida! Agora eu adorei! Era só montar bicho grande e gordo e bom de sela! E pular alto! Ah! Eu adorava! Essa época eu fazia sucesso com as moças e peguei um dinheiro bom também. Ah, eu tinha mais prazer era quando as moças chegavam perto pra ver eu montar. Ô vida minha! Não tinha o direito de pegar na mão de ninguém. Só sacudia a mão pra elas e o bicho tava até urrando debaixo de mim! Eu adorava! Eu fazia tudo na vida pra ver o trem sair gemendo comigo. Batia as esporas nos quiuquiu do bicho e o trem pulava alto demais! Tinha vez que rebentava o arreio todo. Jogava o arreio e eu longe. Vixe, Maria! Esse é bom! Era um cavalo bonito, viu? Um cabelo grande! Não era bom de sela, não, mas era bonito, grande, gordo! Pulava alto! Ah! Aquela casou com um nego feio e doido. Eu falei: - Diabo, se eu sei que era pra desperdiçar com um excomungado que não prestava pra nada, eu tinha descido do cavalo e proposto a ela um namoro, né? Mas ela era bonita demais! Eu fiquei assombradinhozinho. Eu amansei esse cavalo com tanto prazer, que eu falei: eu vou amansar esse cavalo que um dia eu ainda vou encontrar aquela menina 
em riba desse castanhão! Depois ele amansou, ficou um menino manso, ficou igual uma cera... Eu trabalhava o dia todo e quando chegava de noite, pegava ele e chutava no mundo. Montava em pelo, cortava no couro e corria demais! Aí quando eu voltava, papai falava: - "Esse cavalo não presta. Cavalo ruim. Nós vamos vender esse cavalo!” E eu: - "Vende sua égua, pai! Não vai vender meu cavalo, não.” "Que diabo que esse cavalo tá caçando aqui?" - “Ô, pai, deixa o cavalo quieto, sô! Esse cavalo gosta de mim demais." - "Vou pôr ele aqui dentro pra ele viciar entrar aqui? Ponho não! E o dia que você não tiver?" Aí eu falei: - "O dia que não tiver eu, não tem ele também. Nós dois não separa, não. Nós é junto.”

- Antigamente, aqui nesse Morro, ninguém tinha sossego, não. Que esse povo aqui era brigador demais. Eles matavam um, cedo, e amarravam um no pau pra matar de tarde. Tinha vez que matavam era dois de uma vez. Aqui tinha uns homens que achavam que eles eram os donos do mundo. Lá na fazenda do Saco Preto, tem lá até hoje o quartinho que eles batiam nos escravos. Mas isso era antigamente. Naquele tempo, ali, depois daquele córguinho, tinha um engenho de pau tocado a boi. De noite, a gente ia fazer farinha. Quando dava de madrugada, a gente ia pro curral tirar leite. Aí tinha uma desnatadeira tocada a mão pra separar a gordura do leite. Nisso punha nas latas de creme - que eles falavam creme - pra levar pra Curvelo que lá tinha uma fábrica de manteiga._Naquela época, não era luz elétrica, não. Era querosene. Quando nós ia deitar, que apagava a lamparina, era uma coisa de louco o barulho que aquela assombração fazia. Derrubava cadeira, derrubava armário, era um trem fora de série essa assombração. Só vendo! O tanto de coisa que aparecia de barulho! Aí eu sentia assim chegando o cavaleiro, fazendo tchap, tchap, tchap... no rasteio molhado, nos estercos... Aí eu levantava, abria a janela, e não via ninguém. Nada chegava._O primeiro aparelho que chegou aqui foi um rádio antigo. Aí todo mundo gostava de escutar as músicas. Mas a gente tinha vergonha de ir na casa do fazendeiro, então a gente ficava debaixo dum pau, assim, escutando, de longe. Nessa época não existia dinheiro. Ninguém pagava o outro, não. Era troca de dia. Vamos sipor, assim: o amigo tinha uma roça. Aí o povo ia lá pra roça dele e, quando terminava a roça dele, já ia pra roça do outro. Outra hora trocava o dia por mantimento, um toucinho, alguma coisa assim. A gente ia pra Curvelo, no carro de boi - punha 8 bois num carro, rodeia de pau - e ia de pé, guiando os bois. Levava 
lenha pra trocar - que lá também não tinha gás e o pessoal todo comprava lenha levava lenha e trazia querosene, sal, açúcar, o que precisasse. Porque arroz a gente plantava, milho, as outras coisas a gente tinha aqui. De primeiro, todo mundo colhia pra despesa. Eu, pelo menos, eu não comprava arroz, não comprava feijão, não comprava óleo, que eu engordava porco... Era desse jeito, antigamente. Era assim que rodava. Eu já tomei conta de 200 pessoas, já, no serviço. Gente de todo tipo que você pensar. Eram presos que eles juntavam lá em Januária e traziam pra cá. Eram dois empreiteiros. Eles iam na cadeia, tiravam os presos de lá, e traziam pra cá pra trabalhar. Ficavam aí, assim, 45 dias, e iam embora. Pagar mesmo eles num pagavam é nada. Só o comer. Tipo escravo, né? Essa era a vida, de antes. O Morro? O Morro eu subia lá era todo domingo. Eu gostava de caçar. Tinha muito tatu, tinha paca, lontra, veado, catingueiro, capivara, raposão...Tinha muita coisa lá. Tamanduá. Suçuarana. Mas suçuarana não faz mal a ninguém, não. Ela num guenta um grito! Se você gritar, ela corre. Ela casca fora. Ela não encara, não.

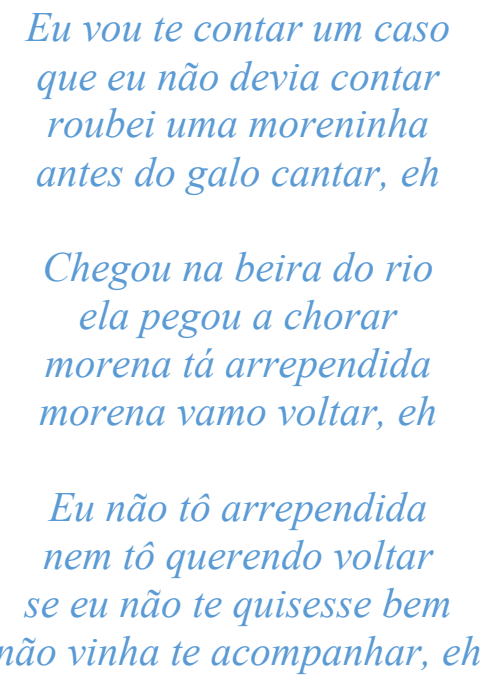

- Eu tinha uma namorada boniiiita! Foi eu mais ela foi os dois primeiros que correram a mão no pêlo um do outro. Vixe! Pra mim era um dengo essa menina! Maria de Lourdes. Era uma cepa de menina boa! Era um trem do outro mundo ela. Era a coisa mais linda que eu achava na vida! Uma morena dos olhos meio esverdeados, cor de papagaio, um cabelo preto desse cumprimento, forte... Pra mim ela tinha tudo pra ser uma mulher boa! Eita! Nós ia casar. Nós era um casalzinho 
muito arrumadinho. A vó dela gostava demais de mim. Já papai pulava pra trás. Virava bicho. Que ele não queria mesmo. Papai, pra casar com nós tinha que descer do céu por descuido, né? - “Ô pai, de lá pra cá Deus não vai mandar, não. O senhor tá enganado com esse negócio. Eu vou arrumar uma mulher é pra mim, não é pra você, não. Ela combinando comigo, eu quero.” Aí com uns 18, 19 anos nós tava namorando direitinho. Desde os 14 em diante nós era namorado. Com 22 anos nós ia casar mesmo. Eu marquei com ela: - "Olha, espera eu sair desses 21 anos - que até os 21 anos eu tenho quem me mande - espera eu sair dele, que nós vamos casar. Se nós não casar aqui, nós foge. Nós vamos fugir e casar longe." Aaah! Aí aconteceu um fato muito triste. Essa menina, eu fiquei sem ela. Não deu certo nós casar. Quando foi um dia, na hora que eu cheguei lá, parece até que eu tava adivinhando - a avó dela falou comigo que não me entregava ela mais não: "Entrego você ela mais não. Não tá do jeito que eu queria, mais. E nem do jeito que você sabe que ela era." Mas eu ainda queria ela assim mesmo. A menina tinha sido...Um sujeito desencaminhou a vida dela, tirou ela do trilho... A velha foi e não quis me entregar ela mais não. Ninguém falou nada um com o outro... E pronto. $\mathrm{O}$ sofrimento foi pesado. A barra ruim. Aí eu falei: eu não quero mais vida com mulher, não. Eu quero agora é sozinho. Namorada eu não quis nunca mais arrumar outra. Todas que mexiam comigo eu falava: - "Meu coração tem uma porteira que já foi fechada e não vai abrir mais não. Cês podem sair fora de mim que eu não quero namorar com você, eu não quero namorar com fulana, eu não quero namorar com sicrana, agora eu vou partir é pra encrenca. Mulher, não! Pode sumir de mim.” Dez anos eu fiquei sem esquecer dela um momento. Até dormindo eu tava vendo ela. Nada me servia. Dormia pouco. Trabalhava de domingo a domingo, sofrendo, amolado... E nada prestou, desse dia em diante... Nunca mais eu prestei também. Nada deu certo pra mim mais. Nada se encaminhou direitinho pra mim. Nada enlerou no jeito pra mim mais. Foi só ruim, só ruim, só ruim. Só o que eu desejava fazer e não fiz era casar, ter uma família, trabalhar juntinho... Mas isso não deu. Agora eu já corro do pedaço. 
- Eu nasci na Capivara-de-Baixo. Lá é município de Corinto. Mas já tem pra onze anos que eu vivo aqui no Morro. Eu fui assim muito namorista, assim, nos meus tempos de boemia, sabe? As moças parece que gostavam demais de mim. Se a gente falar, parece que o povo nem vai acreditar. Eu namorei 153 namoradas. Mulher solteira e moça, sabe? Vai contar, ninguém acredita. Tinha noite que eu deitava na cama, e ia contar quantas namoradas, em tal lugar, tal lugar... Isso acontecia dessas namoradas até brigar umas com as outras e chegava até o padre ir lá separar a briga delas. Enquanto elas tavam brigando, eu saía e ia pra casa de outra, que eu tinha eram muitas, né? Aquilo era uma disputa das moças comigo. É uma coisa que ninguém acredita, é uma coisa que eu devia ter anotado num caderno. Aí eu pensei: Ah, eu vou casar. E muitas moças ricas me propunham casamento. Eu tinha uma malinha, lá, que era cheia de carta de namorada, me pedindo a mão em casamento. Chegavam as cartas molhadas de choro. Mas eu pensava assim: eu sou pobre, eu não vou casar com moça rica, não, né? Então eu vou caçar uma igual a mim que assim ela não pode se queixar. Se ela for se queixar eu digo: eu casei com você porque você era igual a mim, então nós dois tá bom de viver junto. Essa que eu casei chamava Teresa. As outras chamavam Carmen, era Maria Lina, era Áurea Lúcia... Tinha a tal Joaquina, a Neusa, a Diva ... É tanto que o povo ficava até com inveja de mim. Agora eu sou uma pessoa que eu quero só amizade com os outros. Não quero briga com ninguém. Não quero mal querência com ninguém. A gente já passou dos 60, não é? Então a gente tem que caçar é união com todo mundo. Por que a gente vai até os 60 , mais ou menos, e aí já começa a voltar pra trás, a idade. Vai enfraquecendo, vai perdendo a força, vai se tornando criança de novo.

Valha-me Nossa Senhora

Dê juizo a quem não tem

Dê juízo àquela ingrata

Pra tornar me querer bem

- Eu fui nascido e criado aqui no Morro da Garça mesmo. E, agora, Deus me trouxe de volta aqui pra minha terra. Esse barraco, aqui, foi meu pai que fez, tá vendo? Meu pai era um homem muito bom de coração. Então ele fez de barro, assim. Eu não quero desmanchar essa casa nunca na minha vida porque foi aqui que ele me 
gerou. Eu fui gerado aqui dentro. Eu não quero desmanchar essa casa nunca. Então agora eu tô reformando ela. Minha mãe, meu pai comprou isso aqui batendo foice, machado, roçando fazenda, cozinhando carvão. E criou aqui dentro a nossa família. Eu quero colocar a foto desse barraco num quadro, tá vendo? Eu quero colocar aquela parede aqui dentro, tá vendo? Aqui pra mim é melhor do que qualquer lugar do mundo! Aqui pra mim é a mesma coisa que estar numa mansão, rapaz! Eu cresci aqui. $\mathrm{O}$ meu quarto era esse aqui, mais os meninos, quando nós era novo. O meu pai suicidou. Morreu aqui, ó. Ele amarrou a corda aqui, ó, e suicidou. No pescoço. Em cima da cama. A cama de casal da minha mãe ficava aqui. Na época eu tinha 9 anos de idade. Olha, eu vou falar pra você, eu não tenho sabedoria de entender essas coisas, não, sabe? Já perguntei pra minha mãe, se era problema de relação, falta de amor... Ela diz que ele era muito ignorante, batia nela, entendeu? A vida aqui era muito difícil, eles trabalhavam em carvoeiro, cozinhando carvão... Então, ele - diz que era grosso, esses homem grosso, que não tem senso... E aí eu acho que aconteceu essas coisas aí, na briga deles, novo, da minha mãe mais ele, e ele acabou suicidando; problema deles dois. Mas ela não me falou. Já perguntei bastante, mas ela não me falou. Eu acho que a cabeça dele era quase igual a minha, sabe? Mas ele era muito coração bom, então eu acho que ele num guentou. O que eu posso imaginar, ou foi problema com a minha mãe, ou ele num guentou ver as coisa aqui. Porque o diabo tem usado muito as pessoas aqui nessa terra, já há 40 anos, e aí Deus tem dado a eles o castigo. Porque a ira de Deus fica por cima da cabeça da gente. Assim como ele dá as bençãos pra você, ele também permite que as coisas vem acontecer com você. As coisas ruins. Por causa que o Deus que dá as coisas boas é o mesmo Deus que permite que as coisas ruins aconteçam. É o mesmo Deus. Porque eu, eu tô na mão de Deus. Você tá na mão de Deus. Quando você tá no seu carro, você tá na mão de Deus. Quando você tá dormindo, Deus tá te guardando. Quando você tá alimentando, ele é que tá te cuidando. Deus é que tá alimentando. Você tá vendo essa terra vermelha, aqui? Tudo o que você planta dá! Se você jogar uma semente de feijão, ela nasce! Sem você fazer nada, sem cultivar. Só Deus é que faz ela germinar. Quando você pisca e abre o olho, Ele é que tá permitindo você abrir o olho. Ele é que move você. E quando Deus fala: você não vai viver mais, Ele vai e apaga o seu espírito. Morreu. Aonde fala: morreu. Foi Deus que trouxe você aqui e você não sabe. Seus passos são dirigidos por Ele. O espírito do homem é na mão de Deus! A profissão suas, que Deus deu a vocês, são poucas pessoas que 
falam que foi Deus que deu. Como os artistas - ator, atriz - todos foram Deus que escolheu pra eles a profissão. É Deus que escolhe pra nós. É Ele que dirige, não é? Não é a gente que escolhe. Se a gente escolhesse, todo mundo era rico!

Ele é que me dá a minha voz. Não é eu que falo o que eu falo. Ele é que dirige as minhas palavras. Não tem como eu querer ser você. Eu sou eu, você é você, não é? Mas vai sofrer o que eu sofri... Eu dormi no mato, eu comi do lixo...Eu fiquei aqui sem comida, fiquei sem água... Mas eu não abalei co’essas coisas, não. Deus ia cuidando de mim, co'as frutas... Dava uma manga, dava um caju... E aí ele foi me ensinando a viver co’as poucas coisa. Fiquei aqui até sem água pra fazer a comida. Tinha comida e não tinha água pra cozinhar, às vezes! E o povo, eu pedi à menina, ali, e eles brigaram comigo pra me dar água. Me negaram água! É por causa da minha voz. Eles não conseguem ouvir a minha voz. Vinde, povo: senvergonhas, pecadores, homens e mulheres, todos. Todos eu amo, vim por vosso serviço, Deus enviou por mim, ele quer o vosso remimento. Porque o diabo, ele vem pra matar, roubar e destruir. Trazer tristeza, miséria. Então Deus me trouxe pra fazer o contrário, trazer o bem, a paz, a fartura. Então ele me odeia, né? O diabo. Ele quer me ver morto. Por causa que eu sou o ungido, o profeta, o escolhido. Tá vendo a minha voz? - ..É a Voz e o Verbo... É a Voz e o Verbo... Arreúnam, todos, e me escutem, que o fim do mundo está pendurando! Dele tenho o praz-me. Olha o aviso: evém o fim do mundo, em fôgo, fôgo e fôgo!

- Cadê que o mundo acaba! Acaba pra quem morre! O pessoal falou que ia acabar no dia 21. Aí eu levantei cedo, palpei eu, e falei: -“Ops, minha mãe, tô vivo!" Olhei pra riba e admirei: - "Olha o sol aí, minha gente!"

- Eu não acreditei porque eu sei que o mundo não vai acabar. Mas aqui teve gente que tava até adoecendo de medo. Teve gente que nem na rua saiu.

- Teve gente que achou que acabava. Teve gente que vendeu lá muita coisa com medo de acabar.

- Às almas, meus irmãos! O fim do mundo, mesmo, já começou, por longas terras. E vem vindo... Olha os prazos! Vamos rezar, vamos esquentar, vamos ser!

- Desde que eu era menino, o povo fala que o mundo vai acabar. Agora veio essa noticia, de novo. 
- Fim do mundo... Fim do mundo... O cão! Agora que eu estou tão rico... E aquele vem prenunciar o fim do mundo! Uma tana!...

- Acabou em água, uma vez, agora vai acabar em fôgo!

- Acabar? Posso dar meu juramento. Acaba nunca! Isso de mundo se acabar, de noite ou de dia, é invenção de gente pobre...

- Teve um sujeito que chegou lá na minha casa, aquele solão, e ele: - "Ô cumpadre, o mundo vai acabar, cumpadre! Não adianta a gente trabalhar que nós vamos morrer de fome, de sede, assado, cozido, torrado no sol!" Até chorar ele chorou. E eu rindo..."Deixa de ser bobo caboclinho!"

- O mundo já começou a se acabar, e vós semprando na safadeza, na goiosa! Olha o enquanto-é-tempo...

- Será que o mundo acaba?

- Eu tenho pra mim que vai acabar nós, o mundo não acaba, não. Enquanto tiver mulher ganhando menino, vaca tendo bezerrinho, eles dizem...que tiver dando flor, não precisa ter medo que o mundo não acaba, não...E nunca começou também não... teve sempre aí.

- Eu nunca lembrei que o mundo acaba, não.

- Que nada e não. Acabava nunca. Cá, se tivesse o mundo de se acabar, outros, de mais poder e estudo, era que antes haviam de obter sua notícia.

- O mundo acaba é pra quem morre. De vez em quando vai um. Depois vai um punhado. Uns morrem de trombada, outros morrem caído n’água, outros morrem de queda de avião... Bate um caminhão aí, tomba aí, capota aí... Pra esse o mundo acaba.

- O mundo não acaba, não. Tem escrito no catecismo: o mundo não teve princípio e nem terá fim. Esse mundo velho é muuuncho mundo!

- Mas não tem a história de quando o mundo começou? Eles falam. Eu acredito. 
adquiriu família. Adão e Eva, eles falam, mas a gente não pode saber. Eles falam que a minha vó - porque a gente não conheceu os parentes - foi pegada no laço. Existia gente que morava dentro d’água, tipo assim...Outros falam que a gente é descendente dos macacos. Que hoje falam isso. Então, não sei. Eu acho que, quando o Brasil foi descoberto, só tinha macaco aqui. E é desses macacos que nós viemos. Mas tinha também os índios, não é? Os índios já viviam aqui. Junto com os macacos. E aí quando os macacos se transformaram em homens, os índios também se transformaram em seres humanos. E era uma maravilha isso aqui, naquela época. Precisa ver. Era assim, era tudo floresta, tudo tipo aquele jardim do Éden. Já ouviu falar? Então. Deus não falou que era pra não comer da maçã? Não foi assim? Só que, aí, a Eva ficou ali, tentando o Adão: - "Só uma mordidinha, só uma provinha, ninguém vai nem notar...” E aí, ó. Deu no que deu. Depois disso, a vida do homem na Terra só fez decair. Mal tinha começado e já desandou tudo. E quando começa errado, já viu, né? Vai errado toda a vida. Ai de nós! Agora, o começo do mundo, eles falam que o mundo já acabou uma vez, não é? Não tem isso? Vai ver. A questão que eles falam da Arca de Noé. Já não existia, quando o mundo acabou? Não pegou um casal de cada bicho e colocou na Arca? Aí, tinha um casal de gente, que era Adão e Eva, um casal de cada bicho, cada passarinho... Ou isso é lenda? Depois que o mundo acabou, que o mundo secou, a Arca parou. Por isso eu benzo uma pessoa de arca caída através disso aí. Benzo. E cura na hora. Fala assim, ó, nove vezes: Arca de Noé andou, andou, que até encostou. Arca caída volta pro seu lugar. Você fala 9 vezes e reza uma reza que você sabe, uma reza que você goste. Pronto. Tá curado. Mas eu só benzo pra esse mal. Porque o que é que acontece? Quando você benze uma pessoa, o mal dela passa pra você. Então se você benze uma pessoa com mau-olhado, depois você tem que tomar um banho pra tirar aquilo do corpo, praquilo não ficar com você. Bom, mas mais antigamente ainda, o que aconteceu foi o seguinte: antes dos homens, existiam os macacos, e antes dos macacos, existiam os dinossauros. Na época dos dinossauros, eles eram os reis. Aí a Terra foi esfriando, esfriando, esfriando, até que congelou. Daí eles não güentaram. Quando aquela neve toda derreteu, não tinha mais nenhum dinossauro pra contar a história. Tem gente que não acredita. Que acha que dinossauro é assim, que nem dragão. Tipo bicho inventado: unicórnio, cavalo-marinho, esses bichos. É muita ignorância, não é? Mas, então...No inicio era o verbo. E Deus disse: Faça-se a luz. E a luz se fez. E Deus viu que a luz era boa. Aí separou o céu da terra, não foi assim? Depois 
criou as águas, os peixes, os animais até completar o trabalho todo. Depois Ele descansou. Até Deus descansou no sétimo dia. Mas a origem do homem mesmo é dia 25 de dezembro, não é? O dia do nascimento de Jesus, lá em Belém, Belém do Pará, não sei se você conhece. É perto do Rio Amazonas, aquele, que tem aquela história, que a mãe colocou o bebê numa cestinha, e colocou a cestinha no rio, pra quem encontrasse. Já imaginou? Um bebê daquele tamanho, navegando, sozinho, numa cestinha? Só Deus mesmo pra permitir uma coisa dessas. E depois é que veio a época dos castelos, dos reis, dos cavaleiros. Essa é a época mais maravilhosa da história da humanidade. Um verdadeiro conto de fadas. Tinha bruxa que morria queimada na fogueira; tinha cavaleiro com escudo, espada... São Jorge também acho que é dessa época. Pelo menos o jeitão do cavalo dele, assim, parece. Mas na época dele, de São Jorge, o ser humano ainda não tinha pisado na lua, não é? Isso foi bem depois. Tem gente que não acredita. É muita ignorância, não é? $\bigcirc$ pessoal anda dizendo por aí que tá acontecendo coisa, que o mundo vai acabar, que tá esquentando, que o sol tá ficando mais próximo da Terra, que vai explodir tudo... Mas, na minha opinião, isso é lenda. Hoje não tá bom? Não tá fresquinho?! Então. Não é dizer que o sol tá mais forte. Uma época é quente porque tem que ser quente. Eu acho que isso aí é fase. Daqui a pouco vem abril, aí é frio. Depois já vem agosto, é vento, aquele ventinho nojento, sabe? Depois, em setembro vem a primavera e outubro começa o calor. Eu acho que tem que acreditar nas coisas.

- Deus me deu o dom por causa que eu vejo as coisas que eles não veem. É uma visão que a pessoa não vê. Aqui ó. Tá vendo essa pedra que eu achei na rua, ali.? Tá vendo o estilo dessa pedra? Ela é toda quebradinha, assim, parecendo uma piramidezinha... Aí, co’a minha visão, eu falei assim: - Essa pedra tá aqui, no meio da rua, ninguém viu essa pedra, não!? No meio da rua! A pedra no meio da rua. Esse povo daqui não tem criação, não? Quê isso, sô! Aí eu trusse ela e coloquei aí. Essa pedra é criação de Deus - porque Deus é que cria as pedras também. E o Senhor falou: - Se o homem não falar no meu nome - igual se eu não reverenciasse o nome de Deus que tá por cima da nossa cabeça, porque Ele tá escutando aqui as minhas palavras, entendeu? e Ele falou: - Se o homem não falar, as pedras vão falar. Já imaginou!? Você passando perto de uma pedra e a pedra falando pra você: - Leia a 
Bíblia! Jesus tá voltando! Jesus reina! Heim!? Hã!? Aí nego ia até correr, né? Ver uma pedra falando!

- Eu morava na Extrema, trabalhava de vaqueiro... Mais ou menos umas 2 ou 3 horas da manhã, veio a luz andando, no pasto. Parecia uma luz de óleo. Andando.

- O povo fala, não sei, tem um tal de Juvenal, tatuzeiro, ele ia armar gaiola no meio do mato e pedia pra ela alumiá pra ele. E ela aparecia. Aparecia pra ele.

- Essa luz, quase todo mundo já viu ela. Ela não ofende ninguém, não. Ela sempre navega daquele morro, lá, até aquele outro pequenininho que tem ali. O giro dela é sempre esse. Ela sempre aparece.

- Existe ela que eu já vi. Essa luz. É uma luz grandona e branca, ela fica mudando de cor. Mãe do ouro, luz andeja... tem um monte de nome. Mas eu não fiquei com medo, não.

- Ah, faz medo. Não tem como. Porque é uma coisa que não é normal. Não é como um animal que você sabe que é animal. É uma coisa do outro mundo. Mas a onça é pior. A onça come. A onça pega. A onça mata. E a luz não. Agora a origem, isso aí ninguém sabe. De onde veio? O que é que pode ser? Será que ela transforma em outra coisa?

- Eu já vi ela. Ela é tipo uma bola, assim. Ela aumenta se você for encontrar com ela. Você vai, ela vem. Pra te encontrar. Quem já andou por esses lados aí - Vila de Fátima, Janela da Serra, Cavalinho - já viu essa luz.

- Ela fica do tamanho que ela acha que tem que ficar. Ela fica grande, ela diminui... Ela aparece pras pessoas, assim... Se você tiver medo, até que ela vai embora. Agora, se resistir contra ela, ela enfrenta a pessoa.

- Lá em Vila de Fátima, tinha uma passagem duma serra, tipo uma cava dessa assim, ó, o dia que ela tava atentada, lá, ninguém passava.

- Meu tio. Ele tava voltando de uma festa meio doidão já. Aí o carro dele estragou. Quando ele foi abrir o capô, a chave dele caiu dentro do mata-burro. Aí ele 
pediu pra luz iluminar pra ele. E ela iluminou. É assim que ele conta.

- Esse Raimundo, irmão de Fátima, quase acabou com o carro, um dia, por conta dela. Ele tava lá na Fazenda da mãe dele, aí na hora de vir embora, o povo falou com ele: - "Ó, cuidado com a luz que ela pode te seguir! Aí ele: - "Ah, daonde? Essa luz não aparece pra ninguém, não! Isso é ilusão!” Ah! Aí quando ele vinha de lá aqui pro Morrão, ela montou em cima do rabo do carro dele, ela pousou no carro dele, e evém, e evém, immmm, immmm... No meio do mato. Nem ligar o carro ligava. Quase que ele morre. Só pra mostrar pra ele que ela existe. Porque ele abusou com ela.

- Eu já só vi falar nela. Eu mesmo nunca vi ela, não.

- Essa luz... Esse povo andando, aí, pras caçadas, sai, aí, em riba dum caminhão, pega, liga um lanternão, né? E aí, o povo pensa que é luz andando. Eu não acredito, não.

- Eu não acredito, não. Mas eu tenho que acreditar também. Porque um dia, eu passei bem medo também. Eu tava acabando de descer uma serra - só via fogo saindo dos cristal... - e tava um cavaleiro, ali. Aí eu pensei: eu vou correr de modo que eu vou pitar e beber um gole mais ele. Eu tava com um litro de pinga na sela e um cigarrão de palha pronto. Aí, eu apertei meu cavalo, meu cavalo saiu numa disparada, aí quando ia pra chegar perto, era só eu dar uma piscada, e o cavalo dele batia como daqui lá naquela cerca, quase. Uma vez, duas, aí eu pensei: vai matar meu cavalo correr atrás dele assim. Quando eu dei de virar pro outro lado, ele desceu direto. E eu só escutando a zoeira. Aí eu pensei: aquele baiano não quis falar nada comigo e nem me esperar foi por ruindade. Aí, eu sentei, bebi um gole primeira vez que eu bebi um gole na estrada - tô pitando, lá, e o meu cavalinho tá só andando em roda de mim... E eu segurando a corda, e ele andando em roda com a corda. Aí eu: - "O quê que é isso cavalo? Bobo! Você nunca viu o capeta, não!?" Aí o cavalo virou bicho deveras em volta de mim. E eu: uai, vai ver que esse trem aqui pode ser o capeta mesmo! Porque o cavalo tá desse tipo! Eu falei com ele e ele ficou com mais medo! Nisso aumentou a zoeira do estrado do pé do outro cavalo, o que foi diante de mim...Aumentou a zoeira... Poc, poc, poc... Uma altura! Só via 
a zoeira do cavaleiro na estrada. E o cavalinho meu também tava vendo. Mas eu falei com ele que ele arregalasse os olhos porque eu não conhecia o capeta, não. E o cavalinho meu foi ficando doido deveras. E eu: aquilo é o capeta, não é possível. Aí eu pensei, pensei... O que é que pode ser isso? Será que eu não tô muito com Deus? E o trem pra mim não tava bom mesmo não que o povo tava de má vontade demais comigo. Aí eu peguei o cavalo e fui embora. Cheguei em casa e fui dormir dentro do paiol. No outro dia, o cavalo amanheceu com os olhinho arregalado, a barriga vazia, fininho... Parece que dormiu amarrado num pau. Aí eu peguei ele, fui lá no córrego, banhei ele, pus um sal pra ele, olhei a mão dele - tava só um machucão, mas não tava ruim, não. - "Esse cavalo tá sofrendo.” E eu:- "É medo, moço." - "O que que esse cavalo tem que tá fininho desse jeito?" - "É medo. O cavalo tá com medo, ele tá sofrendo." - "O que que foi?" - "Foi assombração. Ontem. E o trem não era mole, não. O trem era feio. Assustou demais mesmo." Aí eu rezei uma oração mais forte, mais depressa, e pedi a Deus pra não deixar as coisas feias me pegar, não. Pra manter as coisa feia longe. Pra ir afastando as coisas feia também. Ah, isso, rezo. Rezo p'ra as almas, toda noite, e de menhã rezo pr'a mim...Pego com Deus. Aí desacismou o cavalo e desacismei eu também. Que eu também tava meio assombrado.

- Eu não tenho medo de capeta, não, que ele não existe.

- Pra mim existe. Existe e não existe. Depende da pessoa. Tem uma história de um homem que ficava fazendo gracinha com o nome do diabo, ali perto da praça, aí o capeta pegou ele de couro lá, num beco perto da casa dele.

- Uma vez, tinha um tal de Dete, doidozinho da cabeça. Aí esse cara ficava: - "Vixe! Vixe!" - "O que que é, Dete?" - “O capeta!" Eu falei: -"Dete, que capeta é esse, Dete?" - "Olha aí, ó! Olha aí, ó!” E eu falei: - "Eu não tô vendo nada, não. É você que tá com esse capeta." - "Nossa Senhora! Nossa Senhora!" “O que que é, Dete?”-“'Ó, o fogo! Ó, o fogo! A sua cabeça tá acabando de cortar o pescoço fora! Pi, pi, pi!" E quase levava a mão pra tirar o fogo que tava pegando em mim. Meu Deus do céu! Você nunca viu um doido daquele jeito! Só ficava falando em capeta, falando em fogo. 
- Um dia desse, aqui, um sujeito veio de Curvelo, saiu lá do pronto-socorro, chegou aí, mandou o povo dele ir embora pra dormir sozinho. Aí quando o povo dele deu uma trégua ele não matou ele? Faca nele mesmo. Aquilo não tava com Deus, não. Aquilo tinha um capetinha junto com ele.

- Acho que, tipo assim: Deus fez as coisas boas e o capeta fez as coisas ruins.

- Mas parece que as pessoas boas, né?, Deus chama elas mais cedo. As pessoas boas Deus quer junto dele.

- É, é que nem trabalhador. Você é bom? Tá dentro. É ruim? Tá dispensado.

- Eu trabalho aqui no cemitério. Quando começa um, vai muitos. Depois pára. Época de frio é época que mais morre. Depois que morre, acabou. Cabou mesmo. Isso aí é fatal. Não tem nada, nada. Não tem como, não. Isso é história. Isso é de antigamente. Hoje não tem isso não.

- O cara que não paga e o cara que paga, depois que morre, é tudo igual?

- Quem faz tudo certo vai pro céu e quem faz tudo errado vai pra baixo. Falam que lá você apanha, lá pega fogo... Mas não adianta. Tem uns que faz errado assim mesmo.

- Uns vão pro inferno, outros vão pro céu. Tem muito bom que vai pro inferno. Igual muitos ruins vão pro céu. Os maus também têm que ter um lugar bom, não é? Lá no inferno agora tá cheio. Eles tão querendo soltar, agora.

- Se o cara foi direito, ele vai morar mais Deus. Então o cara vai estar bem. Já que Ele te chamou pra você morar mais Ele, já que Ele precisou de você pra te chamar... Tudo tem o dia do chamado, não é?

- Porque eu já sei. Já sei o que vai acontecer comigo. Não tem como eu tirar isso de mim. Porque eu sou artista. Sou poeta, cantor, compositor. E essa música minha, que tá aqui na minha cabeça, Ele me escolheu porque eu vou falar das flor, das madeira, das folha, do verde, do amarelo, do azul. Das mulheres, da memória, da 
cabeça, do coração, do rancho, do prédio. Das ruas, das estradas, do asfalto, da terra, dos passarim... De todas as coisas. Da natureza, das diferenças das frutas. Das diferenças das folhas das árvores, os modelos... Então, são muito diferentes as criação de Deus. As folhinhas, cada uma é de um modelo; um verde de uma cor, um verde de outra, o azul, as cores que ele criou. Eu vou falar de coisa que homem nenhum falou ainda. Das cascas da madeira, os desenhos dos paus, os frisos, entendeu? A música, a formiga, o cupim, o carrapato, essas coisas. Das pedras. Da humildade, da simplicidade, do respeito, da verdade, da sinceridade, dessas maravilhas. Do amor, da fidelidade, de tudo! Do anzol, do bambu, tudo! Eu vou falar de tudo que meu Pai criou.

- Essa é a cagaiteira. A folha seca pra fazer o chá é bom demais pro rim que ele é muito fresco. Tem a cervejinha, é uma raiz. É a cerveja mesmo. Você arranca a raiz dela, põe ela pra secar, aí bate ela, põe ela na água... Vai pondo assim, ela escuma igual a cerveja. Pro rim, você nunca viu bom desse jeito! É fresquinho e bom e até bom pra gente tomar. Tem o cajuzinho, é um pequenininho, ele dá sempre mais é na chapada, sabe? Pra diabete é bom demais. Tem o pacari, pra gastrite. Mas tem que tomar pouco. Põe ele, assim, numa vasilha de louça - porque se colocar ele numa vasilha que ele empretece, não pode tomar. Que ele é veneno. Ele é remédio e é veneno. Agora, pondo numa vasilha de louça, pode tomar. E, assim, não toma muito, não. É bom pra gastrite, bom pra qualquer inflamatório. Tem também o nharé, pro sangue. Esse é uma fruta, muito gostoso. Arranca a raiz dele e faz o chá. Pro sangue, pra pele, você nunca viu bom desse jeito. Tem o pau-do-touro, outros conhecem por jurema, o povo fala. Se a pessoa tiver com o intestino desregulado, aí pega ele, tira o entrecasco - tem que ser pouco - põe na água e toma. Num instantinho a pessoa tá boa, tá belezinha, tá sã. Se você tiver andando, no toco, tá com o intestino ruim? Pega assim um pedacinho da madeira, mastiga e loguinho você tá bom. Não precisa nem fazer o chá. Erva cidreira é muito bom também, pra febre, pra muita coisa. Tem o são-catchano*. Ele gosta de dar na seca, assim, dá tipo dum cachinho com a frutinha._Você faz o chá da folha dele, toma ele, não tem febre que não corte. Pode estar queimando de febre, tomou, corta mesmo. Muito boa também é a hortelã-pimenta. Essa é a gente que planta ela, ela não é nativa da terra, assim, não. Pra nervo, bom é o alecrim. Põe o alecrim, abafa ele, toma o chá, 
que ele é bom demais pra nervo. Ele é calmante, o alecrim. Porque tem o maracujá também, muito bom pra acalmar o nervo. Se tomar muito até dorme demais. Tanto pode comer a fruta, como fazer o chá, o maracujá. Esse é um calmante muito bom também. Tem a trançagem, boa demais pra qualquer tipo de inflamação. Pode tomar um golinho ou pode banhar também. Ela é trançada mesmo. Tem o artemijo. O artemijo é bom demais, pra muita coisa. Se a pessoa até tiver meio passando mal, tipo de começar a dar um derrame, tomou o chá, ele recupera. O artemijo é bom demais da conta. Dá uma florzinha. O povo fala. Tem o kitoco também, que é muito bom. O povo até usa socar no tempero pra fazer comida. Vixe! Dá um sabor bom demais. Quitoque. Tem a favaca também. É uma plantinha assim que dá um chá muito gostoso... Pra dor de dente, tem o nharé. Você tira o entrecasco dele e bate ele. Ô! Bochecha a boca, desincha e... Foi dor de dente! É bom demais. Nharé. Pra dor de cabeça tem um tal de capitão. É bom pra olhado ruim, dor de cabeça... Você vai na estrada, ele atravessou uma raiz, ali, você tira. Corta um pedacinho, tira 3 toletinhos, joga um fora, faz o chá de dois, e toma. Não tem dor de cabeça que não melhore. Pra bronquite, assim, aqui a gente usa muito mel de jataí. Sempre faz um chá de camará-do-reino, pega a flor dele, ou flor de mamão-de-corda, aí põe um melzinho de jataí... Você nunca viu bom desse tipo! Mas é bom mesmo. Esses são os remédios que nossa mãe fazia pra nós. Porque esses remédios, que a gente compra na farmácia, são todos feitos de planta. E quase toda árvore é remédio. Somente, às vezes, muitos não conhecem o nome. Igual assim: você tá viajando, dentro da mata, viu uma árvore que o passarinho bicou? Pode comer despreocupado porque, se o passarinho bicou, não é veneno. Antigamente, lá na roça, não existia remédio, quase, não, assim, de cidade. O remédio era ir lá no mato e pegar. Nós fomos criados desse tipo.

Pra tristeza? Ah, remédio pra tristeza é meio difícil. A gente tem é que tomar cuidado pra não deixar ela chegar. Porque eu acho que sempre a tristeza, se a pessoa tiver de mau-amor, aí é que traz a tristeza. Então se a pessoa procura sempre estar de bõamor, não tem tristeza. Comigo, graças a Deus, nunca existiu tristeza. Até hoje não. Teve assim, né?, tem hora que tem uma tristezazinha, assim, naquele momentinho ali... Mas passou, acabou. A tristeza já não me segue. Só ando alegre. 
- Ah, pássaro tem muito, tem demais. Assaz quase milhares. Ichi! De pequenininho a grande, nesse pantanal aí, o que não falta é pássaro. Tem muita garça, tem aquele pato, aquele preto e branco, tem o paturi, tem o marreco, tem a saracura... Tem demais! Aqui tem muito é pássaro! Gavião tem muito. Carcará tem muito. Urubu... Esses passarozinhos pequenos tem demais. Tem joão-de-barro, maritaca, essa pomba verdadeira, tem juriti. Tem demais!

\author{
O engenho velho \\ deu de tremer \\ Põe cana nele \\ Deixa moer \\ Moeu, moeu \\ Virou bagaço \\ Moça bonita \\ Me dá um abraço
}

- Eu sou guaianeiro. A gente fala tirador de guaiana. Eu tenho diversos versos de guaiana. Muitos. A guaiana é o seguinte. Por exemplo, hoje a gente vai fazer a entrega do pé de milho. Aí chegava assim com as enxadas, juntava assim dez, doze camaradas, e logo começava a cantar. Nós cantamos até com cinco vozes. Começa de mim, que tira, que no caso seria o maestro, né? começa comigo e mais quatro. Aí nos cantamos com dois ternos. Um terno de cinco e outro terno de cinco. A gente canta, pára, o outro começa. A hora que eles param, a gente começa. Isso a gente faz capinando roça! Capina a roça e canta. Aí um cara fala assim: Ô, cumpadre, tira isso pra mim! E aquilo outro! E assim nós vamos. Eu aprendi com os mais velhos, com meu pai, meus avós. Isso vem de geração. Mas não todo mundo canta. Tem que ter o pequeno dom daquilo. Tem hora que eu invento assim umas estórias, eu falo uns versos assim, porque aí distrai o dia. Às vezes, a gente vai tomar um aperitivo, aí o povo fala: -“Fala um verso aí, cumpadre!” E eu:

\footnotetext{
Eu fui convidado

Pra festa no céu

Quem fez o convite

Foi seu Manoel

Achei no meu couro

Passagem e hotel
} 


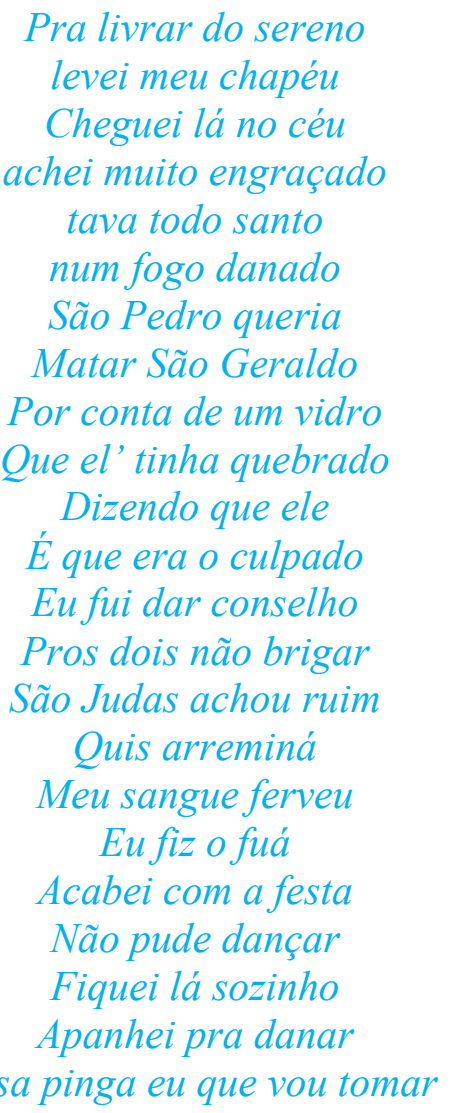

- Eu nasci na Sant'Anna do Ribeirão, onde tem uma capela, aí adiante. Fui criado na roça. Vivi na roça o tempo inteiro. Lá a gente sabe tudo o que acontece com o tempo. A gente já viu isso antes. Aquele bichinho que deu ontem, você lembra? O cupim? O tanto que deu? Bisorrinho. Sol puro. Pode esperar o sol. Não chove mesmo. A lua, quando tá marcando chuva, ela fica assim, ó, derramando. Quando ela é nova, ela não ficca assim? Um risquim? Aí quando ela tá marcando chuva, ela fica assim, ó. Você pode olhar. Ela dá um circulozinho, ao redor dela: chuva longe. Quando dá o círculo longe, aí a chuva é perto. Se tiver pra chover, pode esperar que vai chover. O cupim reforma o cupim. Isso aí você pode esperar que vem chuva. O pau-terra não cai na poeira, e nem a cagaita. E os passarim também adivinha. Tem o rapa-rapa, igual tem aqui, que fica cró-cró-cró... Tem um passarim aqui, que se tiver chovendo e ele começar a cantar, um tal de peixe frito, não sei se você já escutou, de noite ele gosta de cantar: peeexx-fritu. Ah! É sol purim!

- Tudo significa, as coisas. A lima é pra comer a enxada; o serrote; o disco da maqueta; o arreio velho do cavalo; a foice... Isso aqui é um fogãozinho de lenha, 
significando, tá vendo? as coisinhas simples da terra... Essa vasilinha aqui é de fritar um ovo, chama frigideira, você já ouviu falar? Esse aqui, geralmente, eles usam aqui na roça co'o feijão, pra cozinhar o feijão, é o caldeirãozinho; essa botina é de sete léguas, de usar na roça, na água; essa telha é a melhor que tem, é o melhor telhado que tem, é a maior maravilha que Deus já criou no mundo. Esse tijolo aqui é o adobe. É de bosta de boi com areia, não é cimento, não. Faz a massa com a areia e bosta de boi, mistura e passa na parede com a colher. É desse jeito, o adobe. Adobe de barro, sem queimar. É pesado, do próprio barro, tem que pegar com as duas mãos pra colocar na parede. Faz primeiro era com a forma de tábua. Aí seca e coloca na parede já seco. Faz as paredes com ele e reboca com a massa feita com bosta de boi e areia. Esse pratinho aqui é esmaltado, de roça, caipira; a garrafinha de café... Esse canivete aqui é do cabo de osso, tá vendo? Esses osso aí que vocês tão vendo fabrica esse canivete aqui. Esse aqui é o bulezinho de café, significando...um jardim; essa aqui é a tampa da lata de leite, a boca da lata de leite, o selim da bicicleta... Essa aqui é a máquina de plantar arroz, ó, tá vendo? O arroz é plantado dentro dessa máquina. Essa aqui é a enxada pra limpar o arroz. Essa cabaça aqui significa garrafa de água dos trabalhador, que eles levava, antes, pra levar pro campo. Essa bolsa aqui significa quando eu saí daqui, ó, quando eu fui embora. O chinelim, mostrando também que eu era criança, quando eu saí. E essa_caixinha eu pus aí pra receber as correspondências... E aqui tem um violão, ó. Eu catei uns pedaços de tijolo, e falei: eu vou fazer um jardim, aqui. Eu cheguei aqui, quando eu cheguei aqui, eu mostrei procê aquela panela, uma piquinininha? Era aquela panela e o chão. Só. E o resto: uma bolsa. Aí, ó, o que você tá vendo aí, com dois anos que eu adquiri, eu adquiri catando essas coisas aí na rua. Fui catando esses negócio e pendurando aí. Fui catando, trazendo e colocando. Catando, trazendo e colocando. É assim que eu vou fazendo. E assim eu tô indo, e vai ser assim até o fim, até eu morrer! Porque eu sou artista, então Deus me deu essa inspiração de fazer essas coisas. A minha vida é a simplicidade e as coisas. E também sou construtor de usina. Você já ouviu falar em Oscar Niemeyer? A minha cabeça é igual a desses homens, de desenhar e localizar os projetos. Eu tenho essa visão... É dom de Deus, né? Uns acreditam em carro, outros em cavalo, nem todos vão ter fazenda e andar de carro novo, mas pra isso tem que pagar um preço. Já vi o mundo, já viajei de navio, enjeitei andar de avião mas agora eu não quero mais sair daqui não. Que se a gente for andar, a gente quer ir em muitos lugares. Não quero muita coisa, não. Quanto menos, melhor. Eu gosto 
é de pescar lambari ali embaixo, no córguinho. Vou lá, pego seis lambaris, venho aqui, faço um arroz e frito. Eu não tenho nada, não. Só tenho o dia e a noite. Só tenho o dia e a noite mas tá bom. Tem nada melhor que isso, não. Pra mim, não.

\author{
Vou me embora pra São Paulo \\ Meu dinheiro eu vou ganhar \\ Ajustei com a fazendeiro \\ Um grande homem do lugar, eh \\ Fazendeiro perguntou \\ Mas qual que é minha profissão \\ Sou carreiro e sou vaqueiro \\ E também sou um bom peão, eh
}

- E toda aquela viajada, uma coisa logo depois da outra, entupia, entricheirava; só no fim, quando se chega em casa, de volta, é que um pode livrar a ideia do emendado de passagens acontecidas. 


\section{Referências}

AGAMBEN, Giorgio. Genius. In: Profanações. São Paulo: Boitempo, 2008.

ANDRADE, Mario de. O turista aprendiz. São Paulo: Duas Cidades, 1976.

BATAILLE, George. William Blake. In: . A literatura e o mal.

Belo Horizonte: Autêntica Editora, 2015.

BECKETT, Samuel. O inominável. Rio de Janeiro: Editora Nova Fronteira, 1989

BENJAMIN, Walter. O Narrador. Considerações Sobre a obra de Nikolai Leskov. In: Obras Escolhidas.7.ed. Vol. 1. São Paulo: Brasiliense, 1994.

. O Alegorista. Passagens. Belo Horizonte: Editora UFMG, 2006.

São Paulo: Imprensa Oficial do Estado de São Paulo, 2006.

Sobre a a linguagem em geral e sobre a linguagem dos homens.

In:__. Escritos sobre Mito e Linguagem. São Paulo: Duas Cidades; Editora 34, 2013.

A tarefa do tradutor. In: . Escritos sobre Mito e Linguagem.

São Paulo: Duas Cidades; Editora 34, 2013.

BÍBLIA. Português. A Bíblia de Jerusalém. São Paulo: Edições Paulinas, 1987. Livro do Apocalipse.

BLAKE, William. Escritos de William Blake. Porto Alegre, L\&PM Editores, 1984

BLANCHOT, Maurice. A linguagem da ficção. In: A parte do fogo. Rio de Janeiro: Editora Rocco, 1997.

BORGES, Jorge Luis. Obras Completas. Vol. 1 e 2. São Paulo: Editora Globo, 1994.

CAMPOS, Haroldo. Da tradução como criação e como crítica. In:

Metalinguagem. Petrópolis, RJ: Editora Vozes, 1967.

. A linguagem do lauaretê. In: . Metalinguagem. Petrópolis,

RJ: Editora Vozes, 1967. 
Bere'Shith, a cena da origem. São Paulo: Editora Perspectiva, 1993.

CANDIDO, Antonio. O homem dos avessos. In: .Fiç̧ão Completa. João Guimarães Rosa. Rio de Janeiro: Editora Nova Aguilar, 1995. . Depoimentos sobre João Guimarães Rosa e sua obra. In: Grande sertão: veredas. 20a.edição de Rio de Janeiro: Editora Nova Fronteira, 2011.

CARROLL, Lewis. Alice através do espelho. In: Aventuras de Alice. 3 ed. São Paulo: Summus, 1980.

CHAVES, Mario Luiz de Sá et al. Estratigrafia e evolução geomorfológica do grupo bambuí na região de Morro da Garça (MG). In: GEONOMOS. Instituto de Geociências. UFMG. Disponível em: http://www.igc.ufmg.br/geonomos/PDFs/Chavesetal pag43-52.pdf Acesso em: 17 de março de 2017. CARDOSO, Marília Rothier. Uma aprendizagem transcultural nos cadernos de Guimarães Rosa. In: . Literatura e Cultura. Org. Heidrun Krieger Olinto e Karl Erik Schollhammer. Rio de Janeiro. Ed.PUC-Rio; São Paulo: Loyola, 2003.

. O narrador contemporâneo e o arcaico. In: Cenários contemporâneos da escrita. Orgs. Heidrun Krieger Olinto \& Karl Erik Schollhammer. Rio de Janeiro: 7 Letras: Puc-Rio: FAPERJ:CNPQ, 2014. CLIFFORD, James. Sobre o surrealism etnográfico. In: A experiência etnográfica: antropologia e literature no século XX. Rio de Janeiro: Editora UFRJ, 1998.

CLIFFORD, James. Conte-me sobre sua viagem: Michel Leiris. In: Revista de Ciências Sociais do Departamento de Ciências Sociais e do Programa de Pós-graduação em Sociologia da Universidade Federal do Ceará. v.44 n.2 p.137-149, jul/dez 2013 COUTINHO, Eduardo F. Guimarães Rosa: um alquimista da palavra. In:__. Ficção Completa. João Guimarães Rosa. Rio de Janeiro: Editora Nova Aguilar, 1995.

COUTINHO, Eduardo. Encontros. Rio de Janeiro: Editora Azougue, 2008. DELEUZE, Gilles. Platão e o simulacro. In: .Lógica do Sentido. São Paulo: Editora Perspectiva, 1974 
DERRIDA, Jacques. A estrutura, o signo e o jogo no discurso das ciências humanas. In: . A escritura e a Diferença, São Paulo, Editora

Perspectiva.

DIAS, Rosa Maria. Nietzsche e a música. São Paulo: Discurso Editorial, 2005.

DIDI-HUBERMAN, Georges. A Imagem Sobrevivente. História da Arte e tempo dos fantasmas segundo Aby Warburg. Rio de Janeiro:

Contraponto, 2013.

FOSTER, Hal. O artista como etnógrafo. In: . O retorno do real: $A$ vanguarda no final do século XX. $1^{\text {a }}$.ed. São Paulo: Cosac Naify, 2014. FOUCAULT, Michel. A vida dos homens infames. In: O que é um autor? Lisboa: Passagens, 1992. . As palavras e as coisas: uma arqueologia das ciências humanas. São Paulo: Editora Martins Fontes, 1999. GALVÃO, Walnice Nogueira. A linguagem e a fala. In:_..As formas do Falso. São Paulo, Editora Perspectiva, 1972.

GALVÃO, Walnice Nogueira. Metáfora Náuticas. Revista do Instituto de Estudos Brasileiros (IEB), São Paulo, 41: 123-130, 1996.

KLINGER, Diana. Escritas de si, escritas do outro: o retorno do autor e a virada etnográfica. $3^{a}$. ed. Rio de Janeiro: 7 Letras, 2012.

LORENZ, Gunther. Diálogo com Guimarães Rosa. In: João Guimarães Rosa. Ficção Completa. Vol. 1 Rio de Janeiro: Editora Nova Aguillar. 1991.

LEIRIS, Michel. Le sacré dans la vie quotidienne. In:__. Le Collège de Sociologie (1937-1939). Paris, Éditions Gallimard, 1995.

LÉVI-STRAUSS, Claude. Tristes Trópicos. Lisboa: Edições 70, 1993. LINS, Consuelo e MESQUITA, Claudia. Filmar o real: sobre o documentário brasileiro contemporâneo. Rio de Janeiro: Zahar, 2011. MACIEL, Maria Esther. A memória das coisas. Rio de Janeiro, Lamparina Editora, 2004.

MARTINS COSTA, Ana Luiza. João Rosa, viator. In: Sussekind, Flora et al ii (orgs.) A historiografia literária e as técnicas de escrita. Do manuscrito ao hipertexto. Rio de Janeiro: Casa de Rui Barbosa, Vieira e Lent, 2004. P.191-213 
MARTINS COSTA, Ana Luiza. O mundo escutado. In: Revista Scripta, v.9, n17, p.47-60. Belo Horizonte, 2005.

MARTINS COSTA, Ana Luiza. Miguilim no cinema: da novela "Campo Geral" ao filme "Mutum". In: Revista de Ciências Sociais do Departamento de Ciências Sociais e do Programa de Pós-graduação em Sociologia da Universidade Federal do Ceará. v.44 n.2 p.07-269, jul/dez 2011.

MICHAUD, Philippe-Alain. Aby Warburg e a imagem em movimento. Rio de Janeiro: Contraponto, 2013.

NADER, Carlos. No princípio era o verbo. In: . Últimas conversas. Rio de Janeiro: Editora 7 Letras. 2017. . Eduardo Coutinho, 7 de outubro. 73' São Paulo. SESC, 2016 NIETZSCHE, Friedrich. Genealogia da moral: uma polêmica. Trad. Paulo César de Souza. São Paulo: Companhia das Letras, 1998.

NIETZSCHE, Friedrich Wilhelm. Sobre a verdade e a mentira no sentido extra-moral. In: Obras incompletas. Col. Os Pensadores. São Paulo: Nova Cultural, 1991.

NIETZSCHE, Friedrich. Música e Palavra. Fragmento Póstumo Nr.12 [1], da primavera de 1871.Trad. Oswaldo Giacoia Junior. In: Revista

Discurso.n.37. São Paulo, 2007.

http://www.revistas.usp.br/discurso/issue/view/5193

NUNES, Benedito. A Rosa o que é de Rosa. Rio de Janeiro: Difel, 2013. OLIVEIRA, Maria Rosa Duarte de. A ficção literária como antropologia especulativa. In: . Revista da Anpoll, v.1, n.28, P.195-212, 2010.

OTTE, Georg. A letra morta como garantia de sobrevivência. In: Sobrevivência e devir da leitura. (orgs: Eneida Maria de Souza, Dylia Lysardo-Dias, Gustavo Moura Bragança. Belo Horizonte: Autêntica Editora, 2014.

PADILHA, Viriato. Os Roceiros. Rio de Janeiro: Livraria Quaresma, 1956. PLATÃO. Fedro. São Paulo: Editora 34, 2016.

PRADO JR., Bento. O Destino Decifrado. In: . Alguns ensaios: filosofia, literature e psicanálise. São Paulo: Editora Max Limonad, 1985.

RAMOS, Nuno. Ó. São Paulo: lluminuras, 2008.

RANCIĖRE, Jacques. A partilha do sensível: estética e política. São 
Paulo: Editora 34, 2009.

RANCIĖRE, Jacques. O corpo e a letra. In: . Políticas da escrita. Rio de Janeiro: Editora 34, 1995.

ROSA, João Guimarães. Tutaméia: terceiras estórias. 6a.edição. Rio de Janeiro: Nova Fronteira, 1985.

. O Recado do Morro. In: . No Urubuquaquá, no Pinhém (Corpo de Baile). 9a. ed. Rio de Janeiro: Nova Fronteira, 2001.

. Grande sertão: veredas. 20. ed. Rio de Janeiro: Editora Nova Fronteira, 2001.

ROSA, João Guimarães. Campo Geral. In:__. Corpo de Baile. Edição Comemorativa. Rio de Janeiro: Nova Fronteira, 2006.

. A Boiada. Rio de Janeiro: Nova Fronteira, 2011.

ROSA, João Guimarães \& BIZZARRI, Edoardo. João Guimarães Rosa. Correspondência com seu tradutor italiano Edoardo Bizzarri. Rio de Janeiro: Editora Nova Fronteira, 2003.

SAER, Juan José. O conceito de ficção. Sopro. N.15, Agosto de 2009. Disponível em: www.culturaebarbarie.org/sopro Acesso em: março de 2017

SALIM MIRANDA, Pedro. A Natureza nas narrativas dos Moradores de Morro da Garça em Minas Gerais: Encantamento, desencantamento e os causos da "Luz", 2015. Dissertação de Mestrado. EICOS. Universidade Federal do Rio de Janeiro.

SANTIAGO, Silviano. (supervisão) Glossário de Derrida. Rio de Janeiro: Francisco Alves Editora, 1976.

. As Escrituras Falsas São. In: Revista 34 Letras. n.5/6. Rio de Janeiro: 34 Letras, 1989.

SIQUEIRA, Marília Rocha de. O ensaio e as travessias do cinema documentário. Dissertação de Mestrado. Faculdade de Filosofia e Ciências Humanas da Universidade Federal de Minas Gerais TELLES, Luiza Novaes. Buriti: o inarticulado na língua de Rosa. In: Revista Ao Largo. Instituto Superior de Educação Pró-Saber.2016.1 https://www.maxwell.vrac.puc-rio.br/rev aolargo.php?strSecao=input0 VALERY, Paul. Monsieur Teste. Editora Ática, 1997. 
VIVEIROS DE CASTRO, Eduardo. Filiação intensiva e aliança

demoníaca. Novos Estudos - CEBRAP (online). n.77, pp.91-126, 2007. . Entrevistas. Encontros. Rio de Janeiro: Azougue Editorial, 2007. . Metafísicas Canibais. São Paulo: Editora Cosac Naify, 2015.

. O recado da mata. In: A queda do céu: palavras de um xamã yanomami. Davi Kopenawa e Bruce Albert. trad. Beatriz PerroneMoisés. $1^{\mathrm{a}}$.ed. São Paulo, Companhia das Letras, 2015.

WISNIK, José Miguel. Recado da Viagem. In: Revista Scripta. Belo Horizonte, v.2, n.3, p.160-170, $2^{\circ}$.sem., 1998

ZILBERMAN, Regina. "O recado do moro": uma teoria da linguagem, uma alegoria do Brasil. In:_. Corpo de Baile, romance, viagem e erotismo no sertão. Porto Alegre: EDIPUCRS, 2007

ZUMTHOR, Paul. Performance, recepção, leitura. São Paulo: Cosac Naify, 2007. 
seres, coisas, lugares

filme documental: 45 '

versão: abril 2017, não finalizado.

\section{FICHA TÉCNICA}

Direção: Suzana Macedo

Fotografia: Carlos Fernando Macedo

Edição: Renata Catharino

Roteiro: Renata Catharino, Suzana Macedo

Câmeras adicionais: Catarina Carvalho, Davi Mekler, Sergio Mekler,

Suzana Macedo

Captação de som: Catarina Carvalho, Sergio Mekler

Mixagem: Leonardo Monteiro

Correção de cor: Catarina Carvalho

Consultoria de Finalização: Juca Diaz

Consultoria de arte gráfica: Rara Dias

Still: Carlos Fernando Macedo

Produção: Suzana Macedo

Co-produção: Guanabaratejo

Colaboração na produção: João Paulo Castro, Fátima Coelho Castro Elenco:

Antonio Rodrigues Lopes (Seu Tonico)

Carlos Alberto Santos Sousa (Cacá)

Carlos Roberto Diniz (Carlinhos)

Conceição Alves Rocha (Seu Nonô)

Geraldo Magela Lucio (Magela)

Geraldo Nonato da Cruz (Seu Nonato)

Mario Magdaleno de Oliveira (Seu Mauro)

Washington Gomes de Avellar (Washignton)

Os 'reis':

Julmar Ribeiro Rocha

Kennedy Fernandes de Freitas

Ucreitom da Silva Pereira 
AGRADECIMENTOS :

Ana Luiza Martins Costa

Angel Diez

Barrão

Berna Ceppas

Bernardo Barcellos

Bia Lessa

Carlos Nader

Clarice Magalhães

Davi Mekler

Eduardo Macedo

Fátima Coelho Castro

Flavio Tambellini

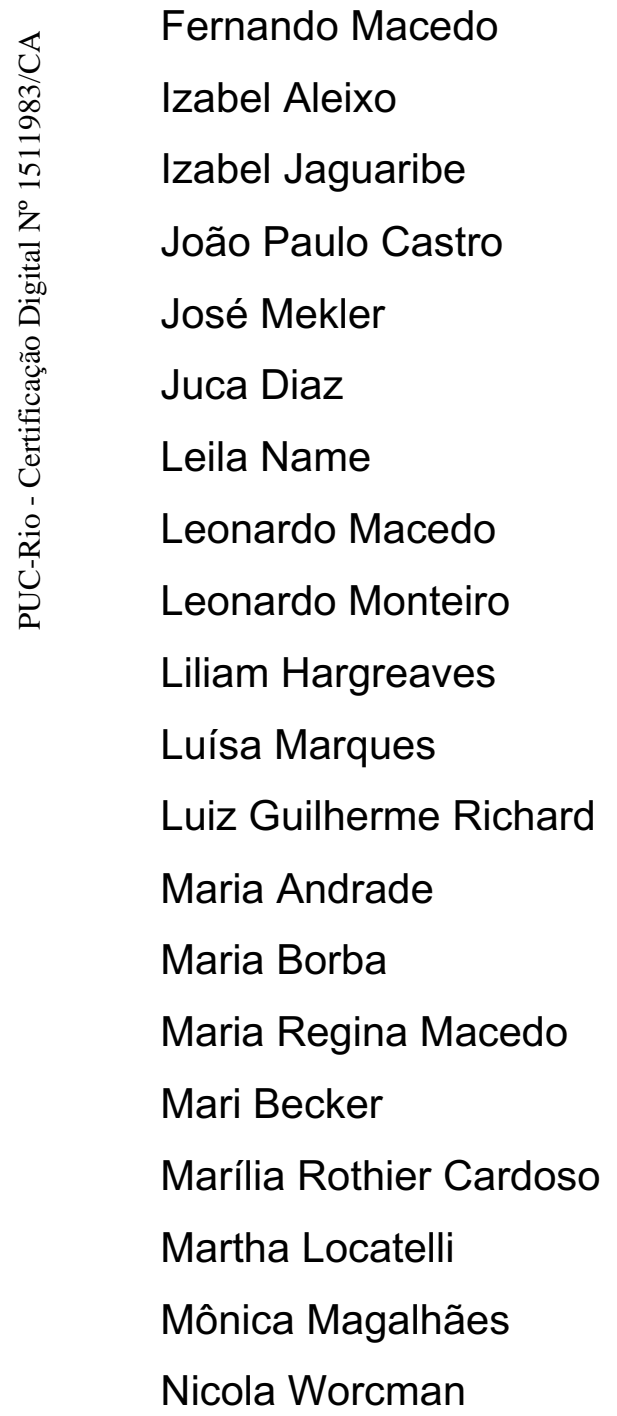


Nilma Gomes (O2)

Pedro Locatelli

Quito Ribeiro

Rara Dias

Regiane Cruz (O2)

Rodrigo Andrade

Ruy Gardnier

Sérgio Sant'Anna

Sonia Magela

Vilma Guimarães

As meninas:

Flaviana Dias Santos

Leidiane Aparecida da Silva Reis

Gabriela Dias Santos

Ana Paula Dias Santos

Helen Dias Santos

Ana Francisca

Alice Giovana 